$(1,10)$

48

a. 
DUDLEY KI:S : L PFATY

WIVL POSTSRADUATE SCHOOL

MONTEREY, CALIF. 93240 




\section{NAVAL POSTGRADUATE SCHOOL Monterey, California}
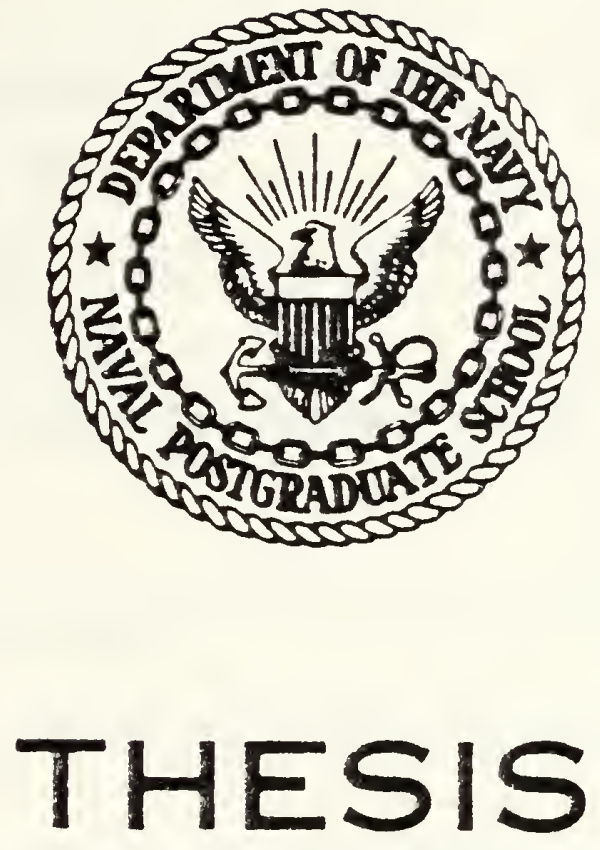

OVERWINTERING STRATEGIES OF THE CALANOID COPEPOD CALANUS PLUMCHRUS

IN A PERIODICALL Y ANOXIC BRITISH COLUMBIA FJORD

\section{by}

Michael Bruce Cowen

October 1982

Thesis Advisor:

E. C. Haderlie

Approved for public release; distribution unlimited. 



\begin{tabular}{|c|c|}
\hline T. TFOOT NUMUL' & 3. RECITIEMT'S CATALOG NUMBER \\
\hline \multirow{2}{*}{$\begin{array}{l}\text { Oritce (and subllos } \\
\text { Overwintering Strategies of the Calanoid Copepod } \\
\text { Calanus } \\
\text { Columbia } \frac{\text { Plumchrus in a Periodically Anoxic British }}{\text { Fjord }}\end{array}$} & $\begin{array}{l}\text { 3. TYAE of REPOAT PEAIOO COVEAED } \\
\text { Master's Thes is } \\
\text { October } 1982\end{array}$ \\
\hline & 6. DeRtonmino org. nepont numDen \\
\hline $\begin{array}{l}\text { 7. Autmoniol } \\
\text { Michael Bruce Cowen }\end{array}$ & 6. CONTAACT OA GAAHT MUMAEA(C) \\
\hline $\begin{array}{l}\text { Denomimo onoamization mame amo aOdREs } \\
\text { Naval Postgraduate School } \\
\text { Monterey, California } 93940\end{array}$ & $\begin{array}{l}\text { To. PROGRAMELEMENTTPROJECT, TASK } \\
\text { AREA WORK UNIT NUMEERS }\end{array}$ \\
\hline \multirow{2}{*}{$\begin{array}{l}\text { 11. COntmollimo office mame amo aooness } \\
\text { Naval Postgraduate School } \\
\text { Monterey, California } 93940\end{array}$} & $\begin{array}{l}\text { 12. AEPOAT OATE } \\
\text { October } 1982\end{array}$ \\
\hline & $\begin{array}{l}\text { 13. MUMEEA OF PACES } \\
109\end{array}$ \\
\hline \multirow{2}{*}{ 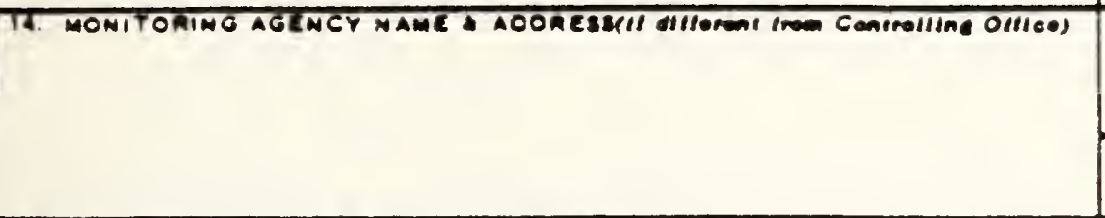 } & $\begin{array}{l}\text { 18. SeCunity Class. (ol mie mopore) } \\
\text { Unclassified }\end{array}$ \\
\hline & $\begin{array}{l}\text { TSE. DECLASSIFICATION/DOWNGAADING } \\
\text { SCMEOULE }\end{array}$ \\
\hline
\end{tabular}

16. DISTRIOUTION STATEMENT (OI InIO REPAPI)

Approved for public release; distribution unlimited.

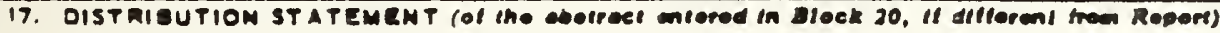

10. SUPPLEMENTARY NOTES

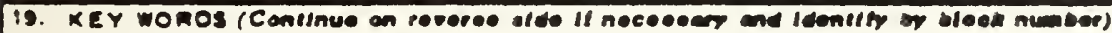

copepod

overwintering

Calanus

Calanus plumchrus ammonia excretion

diapause

feeding behaviour

sonic scattering vertical distribution

anoxic

lipid metabolism

protein metabolism

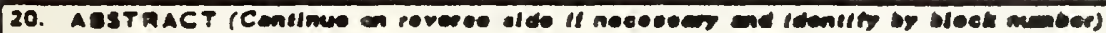

A study was conducted to determine the excretion physiology and feeding behaviour of overwintering Calanus plumchrus $V$ in Saanich Inlet, B.C. In December, no $\underline{C}$. plumchrus $V$ were found above $75 \mathrm{~m}$. $48 \%$ of the population was within $25 \mathrm{~m}$ of the bottom. Oxygen concentrations below $75 \mathrm{~m}$ declined steadily during the winter. By January, water below $150 \mathrm{~m}$ was anoxic. Overwintering c. plumchrus $V$ from Saanich Inlet would not eat under laboratory conditions. 

20. ABSTRACT (continued)

Seven species of cultured phytoplankton and Artemia nauplii were offered as food. Mean ammonia excretion rates were 15.41 and $15.33 \times 10-3$ micro-gm atoms nitrogen per mg dry weight per day. These values are 10-20 times lower than those previously reported for overwintering copepods. It was calculated that $\underline{C}$. plumchrus $V$ had sufficient body nitrogen to survive at least 5 months at the observed rates of nitrogen excretion. It is concluded that $c$. plumchrus $V$ in Saanich Inlet enter into diapause to survive low winter food levels. Feeding does not occur, protein metabolism is low and lipid reserves are not utilized. 

Approved for public release; distribution unlimited

\title{
Overwintering Strategies of the Calanoid Copepod Calanus plumchrus in a Periodically Anoxic British Columbia Fjord
}

by

\author{
Michael B. Cowen \\ Lieutenant (Navy), Canadian Armed Forces \\ B.Sc., University of Victoria, 1975
}

Submitted in partial fulfillment of the requirements for the degree of

MASTER OF SCIENCE IN OCEANOGRAPHY

from the

NAVAL POSTGRADUATE SCHOOL

October, 1982 
Thewo द. $756: 37$ 


\section{ABSTRACT}

A study was conducted to determine the excretion physiology and feeding behaviour of overwintering Calanus plumchrus $V$ in Saanich Inlet, B.C. In December, no $\underline{C}$. plumchrus $V$ were found above $75 \mathrm{~m}$. $48 \%$ of the population was within $25 \mathrm{~m}$ of the bottom. 0xygen concentrations below $75 \mathrm{~m}$ declined steadily during the winter. By January, water below 150m was anoxic. Overwintering $\underline{C}$. plumchrus $V$ from Saanich Inlet would not eat under laboratory conditions. Seven species of cultured phytoplankton and Artemia sp. nauplii were offered as food. Mean ammonia excretion rates were 15.41 and $15.33 \times 10-3$ micro-gm atoms nitrogen per mg dry weight per day. These values are 10-20 times lower than those previously reported for overwintering copepods. It was calculated that $\underline{\underline{C}}$. plumchrus $V$ had sufficient body nitrogen to survive at least 5 months at the observed rates of nitrogen excretion. It is concluded that $\underline{C}$. plumchrus $V$ in Saanich Inlet enter into diapause to survive low winter food levels. Feeding does not occur, protein metabolism is low and lipid reserves are not utilized. 

TABLE OF CONTENTS

I. INTRODUCTION - 10

II . LITERATURE REVIEW - 14

A. DISTRIBUTION AND LIFE CYCLE OF CALANUS PLUMCHRUS -...-- 14

B. PROTEIN AND LIPID METABOLISM IN CALANUS _................ 16

C. THE PROBLEM OF OVERWINTERING NUTRITION

III. METHODS - 29

A. FIELD SAMPLING - 29

B. LABORATORY EXPERIMENTS

1. Feeding -

2. Ammonia excretion -- 35

IV. RESULTS - 37

A. FIELD SAMPLING - 37

B. LABORATORY EXPERIMENTS -

1. Feeding -o 38

2. Ammonia excretion -.- 47

V. DISCUSSION -

VI. SUPMARY -

APPENDIX -

LIST OF REFERENCES -

INITIAL DISTRIBUTION LIST - 



\section{LIST OF TABLES}

TABLE

Page No.

I Phytoplankton Dimensions and the Coulter Counter

Parameters Used to Determine Phytoplankton

Concentrations

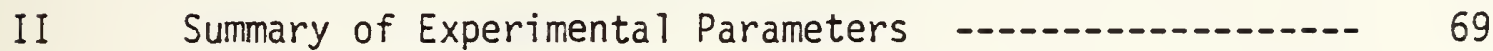

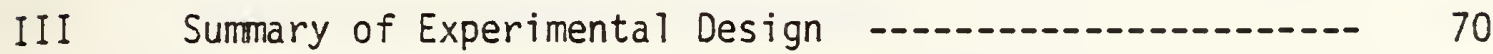

IV Vertical Distribution of $C$. plumchrus $V$ in Saanich Inlet Between 1300 and $14 \overline{0} 0$ hrs, 19 December, 1974 -.- 72

V Station E Summary - Physical Data 17 October, 1974

VI Station E Summary - Physical Data 18 November, 1974

VII Station E Summary - Physical Data 19 December, 1974

VIII Station E Summary - Physical Data 16 January, 1975

IX Strait of Georgia Summary - Physical Data

I November, 1974

$X$ Experiment 9-B. The Ingestion of Artemia sp. nauplii by Calanus pacificus

XI Mean Coincidence Corrected Particle Counts for

Experiment 10

XII The Ingestion Rates of $C$. pacificus Feeding on Different Phytoplankton Cultures in Experiment 10 -.-- 80

XIII Summary of Calibration Factors (F) Determined from Ammonia Standardization Runs

XIV A Summary of the Ammonia Excretion Rates of Calanus plumchrus $V$ from Experiment 11 

XV A Summary of the Ammonia Excretion Rates of Calanus plumchrus $V$ from Experiment 12 ................. 83

XVI Summary of Calanus sp. Nitrogen Excretion Rates _......- 84

A-I Mean Particle Counts for Experiment 1 -..-- 86

A-II Mean Particle Counts for Experiment 2 - 87

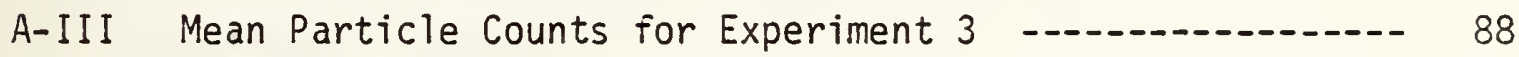

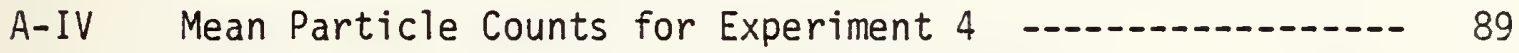

A-V Chlorophyll-a Concentrations of the Feeding Jars at the End of the Feeding Period -...- 90

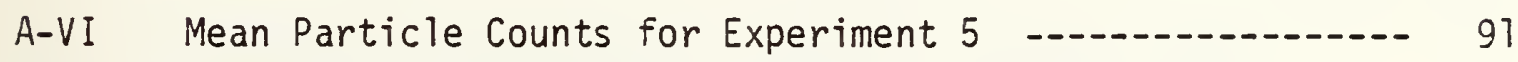

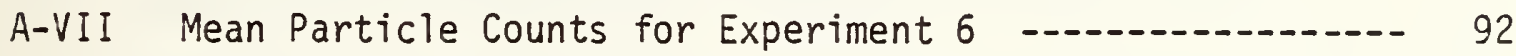

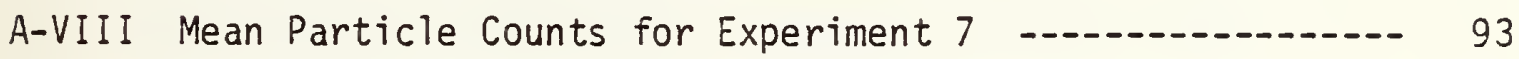

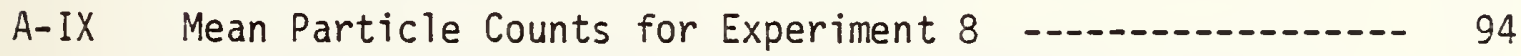

A-X Experiment 9-A. The Effect of $\underline{C}$. plumchrus on the Concentration of Artemia Larvae Over a $24 \mathrm{hr}$ Period -..- 95 



\section{LIST OF FIGURES}

FIGURE

Page iNo.

1: Map showing location of the two sampling stations _.......-. 57

2: Chart showing location of Station $E$ in Saanich Inlet -.---- 58

3: Experimental flowchart - 59

4: Representative fifth leg of Calanus plumchrus $V$-.-.--.--- 60

5: The vertical distribution of Calanus plumchrus in Saanich

Inlet --1-1-1

6: The vertical distribution of sigma-t in Saanich Inlet during October and November

7: The vertical distribution of sigma-t in Saanich Inlet during December and January

8: The vertical distribution of dissolved oxygen in Saanich

Inlet during October and November

9: The vertical distribution of dissolved oxygen in Saanich Inlet during December

10: The vertical distribution of dissolved oxygen in Saanich Inlet during January

11: Regression of mean $\underline{C}$. pacificus ingestion rate (I.R.) on the initial Artemia sp. concentration 



\section{ACKNOWLEDGMENTS}

I would like to thank my advisor, Distinguished Professor Eugene C. Haderlie, and my second reader, LCDR Calvin Dunlap, USN, both of the Naval Postgraduate School for their advice and support during this study.

My sincere thanks are also extended to Dr. Jack Littlepage, Dr. Derek Ellis, Gail Jewsbury, Lucie Maranda, Peter Chapman, Doug and Alex Hartley, and Dr. Pat Gregory, all of the University of Victoria. All were extremely helpful during the initial data collection in 1974/75 but more importantly, during my visits to Victoria in the last two years to work on the data analysis. Their tolerance of my frequent and at times extended telephone calls is also appreciated.

I would also like to thank Allan Baldridge, Head Librarian at Hopkins Marine Station, for assisting me in my library research.

Lastly, but most importantly, I would like to thank Hannah, whose support throughout this study made its completion possible. 



\section{INTRODUCTION}

Sound scattering layers in the sea have been known since the 1930's and intensive investigation in the last 20 years has done much to describe the biological nature of these layers. Most measurements of sound scattering have been made at acoustic frequencies below $30 \mathrm{KHZ}$ where resonant scattering due to fish swimbladders and physonectid siphonophores form the most important contribution (Bary, 1966a and 1966b; Farquhar, 1977). More recently, the use of high frequency precision echosounders in the 30-300 KHZ range has allowed investigators to detect other faunal elements such as copepods, euphausids and pteropods in the water column (Sameoto, 1976; Hansen and Dunbar, 1971). When such organisms are concentrated in large numbers, the scattering of ten takes the form of a distinct layer.

Calanoid copepods form one of the dominant constituents of the zooplankton in the world oceans and play an important role in sound scattering at high frequencies. Castille (1975) speculated that copepods and phytoplankton were responsible for the acoustic volume reverberation he observed at $330 \mathrm{KHZ}$ in the Western Pacific. Bary and Pieper (1971) working in Saanich Inlet, B.C. demonstrated that euphausids and large copepods were responsible for scattering observed at 107 and $197 \mathrm{KHZ}$. A $200 \mathrm{KHZ}$ scattering layer in the North Pacific was found to correspond to large numbers of the large copepod Calanus cristatus (Barraclough et al., 1969). Hopkins et al. (1978) observed that sound scattering at $120 \mathrm{KHZ}$ in a 

Norwegian fjord was caused by euphausids, chaetognaths and calanoid copepods with the copepods comprising $72 \%$ of the biomass.

The investigation of sound scattering in the high frequency range of 30 to $300 \mathrm{KHZ}$ assumes military significance when it is considered that most active homing torpedo transducers and mine countermeasure sonars operate in this frequency range. The French DUBM 21B IBIS and the British Type 2034 minehunting sonars operate at 100 and $110 \mathrm{KHZ}$ respectively (Janés Weapons Systems, 1981/82).

One of the necessary prerequisites to successful acoustic forecasting is to predict the occurrence, location and strength of biological sound scattering. Before this can be accomplished, detailed knowledge of the basic biology of each of the constituents of the scattering layers must be obtained. Specifically, it must be ascertained which physical ocean variables control the distribution of biological sound scatterers. It is to one aspect of this problem that this thesis is addressed.

In 1975, as part of the requirement for an Honours Degree at the University of Victoria, I initiated a study into several aspects of the physiology and ecology of two of the dominant zooplankters in Saanich Inlet, B.C.: the euphausid Euphausia pacifica and the calanoid copepod Calanus plumchrus. The laboratory data on E. pacifica was incorporated into my honors thesis. The laboratory and field data on $\underline{C}$. plumchrus were not processed or evaluated, but were stored on magnetic tape at the University of Victoria awaiting future analysis. It is this raw data which forms the basis of my thesis. 

Calanus plumchrus is a very abundant calanoid copepod in the Northern Pacific Ocean and in the fjords of western British Columbia. It can reasonably be expected to form an important part of the sonic scattering layer in these areas. Fulton (1973a) reported that the stage $V$ copepodite of Calanus plumchrus Marukawa (1921) (hereafter referred to as C. plumchrus V) did not feed during the last seven months of its life cycle. This conclusion was based on two observations: 1) the absence of food material in the gut of either freshly caught or laboratory "fed" animals; 2) no faecal pellets were produced when the copepods were offered either Skeletonema sp. or Artemia sp. cultures as food. Fulton (1973-a) discounted the utilization of stored lipid as a possible food reserve during winter on the qualitative observation that the lipid sac of $\underline{\underline{C}}$. plumchrus "showed little or no reduction of oil reserves" between the months of September and December.

Littlepage and Rose (1974) demonstrated that $\underline{C}$. plumchrus $V$ collected in March actively fed on cultures of Isochrysis. Ammonia excretion approximately doubled when the copepods were starved for a period of 24 hours, indicating an increase in protein metabolism.

A study was initiated into the feeding behaviour of $\underline{C}$. plumchrus $V$. The objective was fivefold: 1) determine if feeding could be induced in overwintering $\underline{C}$. plumchrus $V$ under laboratory conditions; 2 ) measure the ammonia excretion rates of $\underline{C}$. plumchrus $V$ and estimate the importance of protein metabolism as an energy source during periods of reduced primary production; 3 ) determine the vertical distribution of overwintering $\underline{C}$. plumchrus $V$ in Saanich Inlet and relate this to the environmental 

variables that might affect nutrition; 4) formulate a working hypothes is on the nature of overwintering nutrition in the stage $V$ copepodites of C. plumchrus; 5) synthesize laboratory and field data to formulate a discussion on the contribution of $\underline{C}$. plumchrus to sonic scattering in coastal areas. 



\section{LITERATURE REVIEW}

\section{A. DISTRIBUTION AND LIFE CYCLE OF CALANUS PLUMCHRUS}

Calanus plumchrus has long been recognized as one of the most common copepods both in British Columbia coastal waters and in the North Pacific

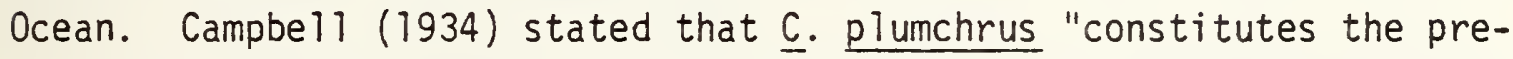
ponderant, constant element of the zooplankton in the Strait of Georgia." Lebrasseur et all. (1969) and Parsons et al . (1969) noted that this copepod virtually dominated the zooplankton biomass in the Strait of Georgia during the spring and summer and was the major food source for young salmon entering the Strait en route to the open ocean. Taguchi and Ishii (1972) working in the Bering Sea and the northern North Pacific noted that "in summer immature (stage V) copepodites of these species ( $\underline{C}$. plumchrus and C. cristatus) constitute $50 \%-90 \%$ of the copepods caught in the euphotic layer." Marioka (1972) reported that $\underline{C}$. plumchrus copepodite stage $V$ "was by far the most abundant (copepod) at nearly all depths on al1 stations" in the western North Pacific while Taka et al. (1981) reported that $\underline{C}$. plumchrus was the dominant copepod species in the Oyashio Current. Vinogradov (1968) cited by Marlowe and Miller (1975) stated that C. plumchrus and $\underline{C}$. cristatus together dominate, in terms of biomass, the zooplankton in the Western Subarctic Domain (which includes ocean station PAPA).

Calanus plumchrus was first described by Brady (1833, cited by Campbe 11 , 1934) under the name Calanus tonsus. The species is closely related to 

C. finmarchicus but is larger and lacks teeth on the anterior margin of the basal joint of the fifth leg (Campbel1, 1934). ‥ plumchrus has been recorded in the North Pacific, southern South Pacific and the mid-Atlantic (Campbe11, 1934). Its Pacific Ocean distribution coincides with that of the Pacific Subarctic water mass. It has been found as far south as $40 \mathrm{~N}$ and as far north as the Bering Sea.

The following summary of the life history of $\underline{\underline{C}}$. plumchrus has been condensed from Campbell (1934) and Fulton (1973): the final molt from the stage $V$ copepodite to the mature adult form occurs between late December and mid-February. Breeding and egg laying take place below 300 meters (in the Strait of Georgia) from January to the end of March. Males die after copulation and the females after the completion of egg laying. Feeding does not occur during the adult life as the masticatory edges of the mandible are much reduced. The maxillae and the maxillipeds are smaller and have fewer filtering setae. Neither size of the brood nor the beginning of breeding depend on the presence or abundance of phytoplankton (Heinrich, 1962).

The nauplii are positively phototropic and migrate to the surface waters at a rate of approximately 26 meters per day. Growth from the first naupliar stage to the Stage $V$ copepodite requires about 74 days with peak abundance of Stage $V$ 's occurring in May. Intensive feeding at the surface by the copepodites results in the deposition of large quantities of lipids. Once lipid storage is complete, usually by early June, the copepods descend into deeper water. The entire population is below 100 meters by the end of July. From August to December there is a further slow migration into deeper water. 



\section{B. PROTEIN AND LIPID METABOLISM IN CALANUS}

Marine invertebrates utilize 3 forms of catabolism: (1) lipidoriented; (2) polysaccharide-oriented; and (3) protein-oriented. In zooplankton, however, polysaccharide metabolism is very minimal (Mayzaud and Martin, 1975).

Lee et al. (1971a) reported that $59 \%$ of the total dry weight of $\underline{C}$. plumchrus was lipid. Lee (1974) further reported that $\underline{\mathrm{C}}$. plumchrus $V$ from Bute Inlet, B.C., was $47 \%$ lipid, with $90 \%$ of this total being in the form of storage lipids and $4 \%$ being incorporated as structural phospholipids. $\underline{\text { c. plumchrus }} V$ from the Bering Sea were shown to conta in $53.5 \%$ protein, $38 \%$ lipids, $2.2 \%$ chitin, $0.9 \%$ carbohydrate and $5.4 \%$ ash (Ikeda, 1972). The very high proportion of storage lipids (wax esters and triglycerides), the relatively low proportion of these which are structural in nature (phospholipids), and the low levels of total body carbohydrate, strongly suggest that lipid is the major food reserve of these animals (Lee et al., 1971b).

Ikeda (1972) determined that $53.5 \%$ of the dry weight of $\underline{C}$. plumchrus was protein. Assuming that ash, carbohydrate and chitin account for $8.5 \%$ of the total dry weight (Ikeda, 1972), the lipid analyses of Lee (1971 and 1974) would indicate that the total protein content of $\underline{C}$. plumchrus ranges between $32 \%$ and $54 \%$.

Nitrogen excretion rates can lead to useful generalizations concerning the importance of protein catabolism in the overall energy budget of an animal. Intensive investigation has demonstrated that calanoid copepods are primarily ammonotelic. Corner et al. (1965) concluded that ammonia 

accounted for a very high proportion of the total nitrogen excreted in C. finmarchicus and $\underline{\mathbf{C}}$. helgolandicus. Corner and Newell (1967) found that between $60 \%$ and $100 \%$ (mean $=74.3 \%$ ) of the total excreted nitrogen in both fed and starved copepods was in the form of ammonia. Small quantities of urea were also excreted but they could not find evidence for the excretion of measurable amounts of amino acids. Johannes and Webb (1965) reported that considerable quantities of amino acids were released by mixed zooplankton cultures but the extremely high experimental densities, roughly equivalent to 5,000 - 70,000 Calanus sp. per liter, make these results suspect (Corner and Cowey, 1968). Butler et al. (1969) examined the forms of nitrogen excreted by $\underline{c}$. finmarchicus at different seasons of the year and found that $78.3 \%$ of the total was excreted in the form of ammonia. Corner et al. (1972) demonstrated that fed and unfed Calanus sp. excreted respectively $87.5 \%$ and $90 \%$ of their total nitrogen as ammonia. C. helgolandicus under either starving conditions or when fed barnacle nauplii excreted between $89.95 \%$ and $91.23 \%$ of their total nitrogen as ammonia with the remainder in the form of urea (Corner et al., 1976). There was no evidence that a greater proportion of nitrogen was excreted as urea with increasing food levels.

The extensive literature on copepod nitrogen excretion rates has been reviewed by Corner and Davies (1971). The values of excretion rates, in micro-grams of nitrogen/mg dry body weight/day, have ranged from 0.30 (Conover and Corner, 1968) to 38.1 (Corner et al., 1967) and are summarized in Table XVI. The large variability reported in the literature may be attributed to a wide range of factors including: differences in 

food levels, body sizes, experimental temperature, salinities, species and analytical techniques (Corner and Davies, 1971).

Conover and Corner (1968) were unable to detect any significant difference in nitrogen excretion rates between fed and starved animals. However, a number of workers (Corner et al., 1965; Conover and Newe11, 1967; Butler et al., 1970; Corner et al., 1972; Corner et al ., 1976 and Ikeda, 1977) have reported that nitrogen excretion is substantially higher in laboratory fed compared to starved animals.

Research into seasonal variation of Calanus sp. nitrogen excretion has yielded results consistent with those just described. Excretion rates were directly correlated with phytoplankton abundance, reaching the highest levels during the spring bloom, declining steadily during summer and fall and reaching their lowest levels in January and February during the period of lowest phytoplankton biomass (Conover and Corner, 1968; Butler et al. 1969; Butler et al., 1970). These results can be explained on the basis that nitrogen is excreted as a result of two processes: (a) deamination of assimilated food protein; the resulting carbon skeleton may be used to form lipid, a process which would be maximal during the period of rapid growth and lipid storage that occurs with the spring bloom (Butler et al., 1970) and (b) tissue protein catabolism, which would form the major source of excreted nitrogen during periods of low food levels (Corner et al., 1965).

Variable results have been reported from studies into the relative importance of lipids and proteins as sources of stored energy during periods of low food abundance. Conover (1962) tentatively suggested that 

C. hyperboreus utilized a "mixed substrate when food (was) available, shifting to a fat metabolism under starvation." Conover (1964, cited by Corner and Cowey, 1968) demonstrated that over a 14 week period of Taboratory starvation, lipid accounted for most of the weight lost in $\underline{C}$. hyperboreus. Conover and Corner (1968) noted that lipid was the primary energy source for $\underline{C}$. hyperboreus during the fal17. As fat reserves were reduced, protein was more heavily utilized with a corresponding increase in nitrogen excretion, though this was not observed until late in the winter. From November to March, $45 \%$ of the total body nitrogen was lost. During the same period, lipid levels dropped from $52 \%$ to $25 \%$ of the total dry body weight. $\underline{C}$. hyperboreas collected from the Arctic Ocean on a monthly basis displayed a similar seasonal pattern (Lee, 1974). Lipids formed $75 \%$ of the tota 7 dry body weight in August after a summer of intense feeding and declined to $29 \%$ by the following June after a long winter in phytoplankton-deficient water. The above results were interpreted to suggest that the lipid was the primary energy store with protein reserves being utilized only when the lipids had been exhausted (Conover and Corner, 1968; Lee, 1974).

Orr (1934) found no significant change in the lipid levels of $\underline{C}$. finmarchicus $V$ during winter. However, in 1958, Marsha 17 and Orr showed that overwintering Stage $V \underline{C}$. finmarchicus lost a large proportion of their lipid content from autumn through January. Gatten et a]., (1978) confirmed these results by recording a sharp decline in the total lipid of Stage $V \underline{C}$. finmarchicus during the winter period. 

There is some evidence to suggest that protein catabolism is an important energy source when food is scarce. Linford (1965) observed that lipid levels remained constant for $\underline{\underline{C}}$. helgolandicus starved for 8 days. Cowey and Corner (1963b) observed that 90\% of the total weight lost by C. helgolandicus during 14 days of starvation was in the form of amino acids. Conover and Corner (1968) interpreted Harris' 1959 study as showing that Acartia sp. were catabolizing protein during a period of low in situ food levels. This was later confirmed by Mayzaud (1974) who showed that Acartia clausi utilized a predominantly protein catabolism during starvation. Mayzaud (1976) believed that some copepods can utilize both proteins and lipids. He stated that $\underline{C}$. finmarchicus "appeared to be able to switch several times during the starvation period from a predominantly protein catabolism to a predominantly lipidic catablolism and vice versa." He felt that this overwintering strategy would help to conserve body protein which cannot be depleted below a certain level.

The relative importance of protein and lipid metabolism in $\underline{C}$. plumchrus has been investigated. Fulton (1973a) concluded that there was no reduction of lipid reserves in animals retained for 3.5 months in filtered seawater. These results were based on visual observations of the size of the oil sac. Lee (1971) showed that 1ipids composed $59 \%$ of the total dry weight in female, adult $\underline{C}$. plumchrus. It is known that adult $\underline{\mathrm{C}}$. plumchrus do not feed and that lipid reserves are totally exhausted during the egg laying process (Fulton, 1973). It must therefore be assumed that Lee's (1971) analyses were conducted immediately prior to egg laying. This 

would indicate that overwintering $\underline{C}$. plumchrus $V$ do not utilize their lipid reserves as a supplemental energy source.

Recently hatched $\underline{C}$. plumchrus from Saanich Inlet when starved under laboratory conditions demonstrated much lower ammonia excretion rates compared to fed animals (Ikeda, 1977). These results are similar to reports by Corner et al . (1965), Corner and Newell (1967), Butler et al . (1970), and Corner et $\underline{\text { al }}$. (1972) that starving $\underline{C}$. finmarchicus and $\underline{C}$. helgolandicus had the lower excretion rates when compared to fed animals. However, these findings contradicted those of Littlepage and Rose (1974) who investigated the possible role of protein catabolism as an energy reserve during laboratory starvation. They found that ammonia excretion levels in late winter Saanich Inlet $\underline{C}$. plumchrus $V$ were approximately twice as high in starved as in fed copepods.

There are fundamental differences between the life cycles of $\underline{C}$. plumchrus and both $\underline{\mathrm{C}}$. finmarchicus and $\underline{\mathrm{C}}$. helgolandicus which might account for their differing responses to starvation. $\underline{C}$. finmarchicus and $\underline{C}$. helgolandicus start breeding only in the presence of the large quantities of phytoplankton that accompany the spring bioom (Heinrich, 1952). Egg production is severely inhibited by the absence of food (Marshall and Orr, 1955). Gatten et al. (1980) states that "egg production (in $\underline{\text {. helgolandicus) }}$ is specifically dependent on the level of lipid in the phytoplankton and its assimilation by the copepods." $\underline{C}$. plumchrus is one of the few copepods that does not feed as an adult and where egg production depends entirely on stored energy reserves (Campbe11, 1934). Littlepage and Rose (1974) hypothesized that non-utilization of lipids (Lee, 1971; Fulton, 1973) 

during winter is primarily a reproductive modification allowing for retention of lipid stores for reproduction. Utilization of body proteins, as indicated by increased ammonia excretion in "starving" animals would serve to supplement low in situ food levels.

\section{THE PROBLEM OF OVERWINTERING NUTRITION}

Overwintering, herbivorous zooplankton that do not vertically migrate and live below the euphotic zone are faced with the problem of obtaining sufficient food in the virtual absence of living plant material. The following is a brief survey of the literature concerning modes of alternative nutrition that have been demonstrated or are potentially available to a herbivore.

The problems associated with overwintering nutrition have been recognized by Digby (1954), Marshall and Orr (1958), Adams and Steele (1966) and Butler et al. (1970). All of these workers have predicted that a switch to a carnivorous habit and/or detrital feeding would be the most likely adaptation to low phytoplankton levels. Calanus sp. has been shown to be at least partly carnivorous. Marshall (1928, cited by Adams and Steele, 1966) noted that between $27 \%$ and $48 \%$ of the copepods examined had crustacean remains in their guts. Anraku and Omori (1963) demonstrated that $\underline{C}$. finmarchicus would eat Artemia sp. nauplii in the absence of plant food but would selectively filter phytoplankton in a mixed culture. Conover (1966) similarly demonstrated that Calanus sp. would capture and eat Artemia sp. nauplii. Mullin (1966) showed that 19 species of Indian Ocean copepods would readily eat Artemia sp. 

The omnivorous copepod $\underline{\mathbb{C}}$. pacificus fed disproportionately on the prey in greatest relative abundance when given a choice of phytoplankton or copepod nauplii in the laboratory (Landry, 1981). This "switch" from herbivory to carnivory in response to a shortage of phytoplankton would be of significant value during the overwintering period. Corner et al. (1974 and 1976) demonstrated that total revels of body nitrogen and phosphorus could be sustained indefinitely in $\underline{C}$. helgolandicus when fed living and dead nauplii of the barnacle Elminius modestus. These researchers concluded that Calanus sp. probably survives the winter in the Clyde Sea by feeding carnivorously, being unable to derive adequate nutrition from either detritus or organic aggregates.

The role of detritus as a zooplankton food source has been the subject of much speculation. Riley (1959 cited by Corner and Cowey, 1964) observed that large quantities of detritus were present in Long Is land Sound and that zooplankton assimilated more nitrogen than was found in the phytoplankton. Corner and Cowey (1964) interpreted these results as evidence for detrital feeding. Parsons and Strickland (1962) attributed only $0.2 \%$ of the total dry plant organic matter in the northeast Pacific Ocean to living plant matter. Biochemical analyses have established the nutritive value of detritus by demonstrating the presence of a wide range of amino acids and carbohydrates (Parsons and Strickland, 1962; Cowey and Corner, 1962, i963a,b; Corner et al., 1974).

Many authors (Digby, 1954; Marsha 11 and Orr, 1958; Parsons and Strickland, 1962; Jorgenson, 1962; Adams and Steele, 1966; Mu17in, 1966; Martin, 1968; Butler et al., 1970 and Raymont, 1971) have speculated that 

detritus plays an important role in the nutrition of zooplankton. Among the first to investigate the possible use of detritus by copepods were Paffenhofer and Strickland (1970). They observed feeding on both senescent and fresh, lightly disintegrated $\underline{C}$. helgolandicus faecal pellets. However, when offered natural detritus, $\underline{C}$. helgolandicus appeared "unable or unwilling to make use of any of the 'structureless' detritus." Paffenhofer and Strickland (1970) concluded by stating that selectivity was probably more a function of physical shape than nutritive value.

The use of faecal pellets as a food source was demonstrated by Paffenhofer (cited by Marsha11, 1973 as a personal communication) when he raised Calanus sp. from copepodite III to adult on a diet of faecal pellets. He concluded that detritus was of little or no food value except in the form of faecal pellets or bacterial aggregates. Vinogradov (1962) theorized a similarly important role for faecal pellets. He postulated that vertically migrating zooplankters feed at surface, but only partially digest their food. A portion of this food would be later released as faecal pellets when the animals descended and would serve as food for deep living non-migratory zooplankton.

The unsuitability of detritus as a food source has been demonstrated by Corner et al. (1974). A test diet of natural suspended matter at a concentration five times the winter Clyde Sea levels failed to sustain either body nitrogen or phosphorus in $\underline{C}$. helgolandicus over a period of five days. The copepods fed on the detritus and produced faecal pellets, but both fed and unfed control animals lost $27 \%$ of their nitrogen and $33 \%$ of their phosphorus, indicating that natural detritus was ingested but 

was of no or little nutritive value. The estuarine copepods Eurytemora affinis and Scottolana canadensis do not survive well or produce eggs when feeding on detritus that has been autoclaved but thrive on detritus which is rich in bacteria and ciliated protozoans (Heinle et al., 1977).

Some forms of bacteria are capable of sustaining growth in freshwater cladocerans and molluscs (Jorgenson, 1962). Bacteria in the free state, because of their small size, are probably not an important part of the copepod diet (Marsha11, 1973). However, a great many marine bacteria are epiphytic, growing on the surface of particulate matter or can occur in aggregates large enough to be caught in filtering setae (Raymont, 1971). Information on bacterial biomasses is scarce due to the difficulty of separating epiphytic bacteria from their substrates. Seki and Kennedy (1969) concluded that bacterial aggregates in the Strait of Georgia were present during winter in quantities equivalent to the total biomass of phytoplankton and were potential sources of food for filter feeders. The role of bacteria in zooplankton nutrition has not been clearly elucidated.

Approximately $90 \%$ of the organic carbon in the ocean is present in the form of dissolved compounds (Holm-Hansen, 1971). Direct uptake of dissolved organic matter through the arthropod epidermis has been discounted as improbable (Corner and Cowey, 1964). However, (Chapman, 1975) indicates that dissolved glucose can be actively taken up by overwintering C. plumchrus and concentrated to four times the ambient level over 24 hours. The significance of this uptake in the overall nutrition of the animal has not been determined. 

Baylor et $\underline{\text { al }}$. (1962) and Sutcliff et al . (1963) discovered that organic particles could be formed in the laboratory by bubbling air through natural seawater. It was found that the growth of Artemia sp. could be supported by aggregates formed in this manner (Baylor and Sutcliffe, 1963). Studies undertaken in Long Island Sound (Riley et al., 1963), the North Atlantic Ocean (Riley et al., 1964) and the Sargasso Sea (Riley et al., 1965) indicated the presence of large quantities of organic aggregates similar to those produced in the laboratory. It was hypothesized that this material originated by adsorption of dissolved organic matter on subsurface bubbles, detritus or bacterial clumps (Riley, 1970). Sheldon et al. (1967) concluded that particle formation was not restricted to the surface interface but could occur spontaneously at greater depths. The formation of organic aggregates and their subsequent consumption by zooplankton has been an attractive but largely unproven mechanism for utilizing the vast reserves of dissolved organic matter present in the ocean (Paffenhofer and Strickland, 1970).

Corner et al. (1974) demonstrated that water removed from the Clyde Sea in winter would not yield organic aggregates unless enriched with soluble extracts of plant cells. Furthermore, copepods fed this enriched "sea foam" lost about $21 \%$ of their total body phosphorus in five days. They concluded that organic aggregates alone could not sustain overwintering Calanus sp.

It has been suggested that Calanus $s p$. may greatiy reduce their metabolism during periods of food scarcity. Beyer (1962) concluded that copepods "hibernated" over winter. Marshall and Orr (1958) also 

considered "hibernation" as a possible adaptation to low food levels. They noted that winter respiration rates were much lower than peak spring rates but concluded that real "hibernation" did not occur: the population lived in an "economical way" by using little oxygen, living in deep water and not undertaking vertical migration. Conover (1962) and Conover and Corner (1968) similarly demonstrated greatly reduced winter respiration rates. The latter authors likened this metabolic slowdown and ability to arrest normal development to insect diapause. A similar conclusion was reached by Hallberg and Hirche (1980) who discovered that overwintering $\underline{C}$. finmarchicus and $\underline{C}$. helgolandicus have a much reduced midgut epithelium, low digestive enzyme activities, very low respiration rates and "arrested development" which they considered as "an expression of a physiological condition that closely resembles the diapause of fresh water cyclopoids and insects."

Cowey and Corner (1963b) tested the hypothesis that Calanus sp. survives the entire winter without feeding. High levels of nitrogen excretion and mortality after 14 days of laboratory starvation led them to conclude that copepods must eat regularly in order to survive. The experiments were repeated in 1970 (Butler et al.) when it was found that total body reserves of nitrogen and phosphorus significantly decreased during periods of starvation. Although daily food requirements were calculated to be less than those during summer (as a result of reduced metabolism) it was concluded that Calanus sp. must feed during the winter. Nutrition was supplemented by the metabolism of body lipids and proteins. Approximately $50 \%$ of total body nitrogen and $25 \%$ of the total phosphorus 

were metabolized by overwintering Calanus $s p$. between the months of October and February (Butler et al., 1970).

Harding (1974) examined the guts of a large number of deep sea copepods collected from depths below 1000 meters and concluded that they fed on a combination of detrital material (faecal pellets, cysts, organic aggregates, diatom tests, etc.), sinking carcasses of larger animals and dissolved organic materials. None of the zooplankton Harding investigated were calanoid copepods of the species previously mentioned in this review. 



\section{METHODS}

\section{A. FIELD SAMPLING}

Zooplankton samples were collected biweekly from October to January, 1974-75 at Station E (Lat. 4831 'N., Long. $12330^{\prime}$ W.) in Saanich Inlet, British Columbia (Fig. 1 and 2). The maximum depth at this location is 206 meters. Horizontal tows using a Nitex 223 one-meter net with closed cod-end were conducted at depths between 170 and 195 meters. The zooplankton were sorted into several plastic buckets (10 liter capacity) which were stored on ice for transport back to the laboratory. Calanus plumchrus were removed and stored at $9 \mathrm{C}$ at a density of 100 per $101 \mathrm{iter}$ bucket in sea water collected from 100 meters and twice filtered through a 0.45 -micron membrane filter. Aliquots were removed from the buckets every 12 hours for the first three days after capture and examined for faecal pellets.

Positive identification of $\underline{\mathrm{C}}$. plumchrus was made using the keys and detailed species descriptions provided in Brodskii (7950), Fulton (1973b), Campbel1 (1934) and Tanaka (1956).

Vertical distributions of chlorophyll-a, salinity, temperature and dissolved oxygen were determined monthly (Oct. to Jan.) at the sampling station. Nansen bottles equipped with reversing thermometers were used to measure temperature and collect water samples for dissolved oxygen and salinity determinations. The oxygen samples were fixed with manganous sulphate and alkaline iodide on shipboard. A PVC Niskin sampler was used 

to collect water for chlorphyll analysis and later experimental use. A vacuum filter apparatus was used on shipboard to filter 3.0 liter water samples through Gelman glass fiber type A filters for chlorophyll determinations. MgCO3 was added prior to the filtration of the samples to prevent acid hydrolysis of the chlorophyll (Strickland and Parsons, 1968). Filters were stored on ice in blackened jars containing silica gel and then frozen at $-20 \mathrm{C}$ upon return to the laboratory. Small water samples from several depths below 75 meters were preserved with a solution of acetic acid and iodine for later identification of the phytoplankton present.

Salinity was measured with a Bissett and Berman Hytech M Model 6220 Salinometer. Dissolved oxygen was determined using a modification of the Winkler titration method of Strickland and Parsons (1968) described in Drinnan and Littlepage (1971). Samples were analyzed one to four weeks after fixation.

Chlorophy11-a concentrations were determined with a modification (Drinnan and Littlepage, 1971) of the trichrometric method of Strickland and Parsons (1968). The absorbances of the chiorophyll extracts were measured in 10-cm small volume cuvettes on a Perkin Elmer (Model 46) Spectrophotometer. The SCOR/UNESCO equations (Strickland and Parsons, 1968) were used to convert absorptions to chlorophyl1-a concentrations.

Vertical distribution of $\underline{\underline{C}}$. plumchrus $V$ was determined by means of a series of vertical hauls employing a horizontally rigged Nitex 223 onemeter net with a wire mesh flow-through cod-end. The net was quickly lowered to the desired depth $(75,100,125,150,175$, or 200 meters) and 

immediately returned to the surface where the animals were preserved in formalin. Animals were counted and population densities computed in June, 1981.

C. plumchrus and water samples were collected on November 1, 1974 from a station in the Strait of Georgia midway between Nanaimo and Vancouver, B.C. (49 15.8'N., 123 44.2'W.) (Fig. 1). A Nansen cast was made to determine salinity, temperature and dissolved oxygen levels at a depth of 400 meters (sonic depth $=414$ meters). A Niskin sampler was used to collect water from 400 meters for chlorophyll analysis, phytoplankton and detritus identification and later experimental work.

A "Bongo" vertical closing net (Koeller, 1975) was used to collect zooplankton on two hauls. The depth intervals sampled were 350 to 410 meters and 330 to 400 meters. c. plumchrus were isolated from each haul and stored on ice in plastic buckets for transport back to the laboratory where they were transferred to 0.45 -micron double filtered, 400-meter water.

\section{B. LABORATORY EXPERIMENTS}

Seven different phytoplankton cultures were used in the feeding experiments and are listed in Table I. The approximate dimensions of each phytoplankter as measured with an optical micrometer are also included.

Al1 cultures were grown under fluorescent light at 9 to $12 \mathrm{C}$ in the growth medium described by Guillard and Ryther (1962). Water obtained from a depth of 100 meters in Saanich Inlet was twice filtered through $0.45-$ micron Millipore filters and autoclaved prior to addition of nutrients and 

vitamins. The growth of the cultures was monitored by daily cell counts with a Model B Coulter Counter (Table I).

\section{Feeding}

In the first eight feeding experiments, $\underline{C}$. plumchrus were offered phytoplankton cultures. In Experiment 9, freshly hatched Artemia sp. (brine shrimp) nauplii were supplied. Experiment 10 was conducted when it became evident that a control was required to ensure that lack of feeding by $\underline{C}$. plumchrus was not caused by the experimental design and laboratory conditions. Calanus pacificus was chosen as the control animal and was offered all seven phytoplankton cultures and Artemia sp. nauplii.

The general laboratory procedures were similar in all phytoplankton feeding experiments and are described below and in Figure 3. However, each experiment differed from the others in such parameters as the number of replicates, copepod densities, duration of experiment, species, age and concentration of cultures. These parameters have been summarized for each experiment in Tables II and III.

Phytoplankton cultures were stored in the dark for 5 to 10 hours to ensure that cell division would be reduced prior to the start of the experiment. Logarithmic phase cultures were used in all experiments except Number 6 where age was an experimental variable. The cultures were diluted to the desired concentration with 0.45-micron double filtered seawater.

The general experimental design was as follows:
Control I
filtered seawater (f.s.w.) only
Control II
f.s.w. + copepods 



$$
\begin{array}{ll}
\text { Control III } & \text { f.s.w. + phytoplankton } \\
\text { Experimental } & \text { f.s.w. + phytoplankton + copepods }
\end{array}
$$

$920 \mathrm{ml}$ glass jars were used as the feeding vessels and filled with $800 \mathrm{ml}$ of one of the above four combinations. The number of replicates and the plankton species and concentration(s) used in the three controls and the experimental jars are summarized in Table II for each of the feeding experiments.

The "f.s.w. only" jars were designed to monitor any increases in particle concentrations during the experiment due to reaggregation of particles (Sheldon et al., 1967). The "f.s.w. + copepods" jars gave an indication of any increase in particle counts due to the animals, e.g., faecal pellets or the release of particulate matter associated with the external surfaces of the copepods. Changes in the phytoplankton population due to cell division or mortality were monitored by the "f.s.w. + phytoplankton" controls. The copepod feeding rates were determined by the differences in phytoplankton concentrations before and after the feeding period as corrected by the 3 sets of controls.

A11 animals were "starved" in 0.45-micron filtered seawater for a minimum of 4 days prior to the start of the experiment. Ten animals were selected at random and the fifth legs examined to ensure positive identification of Calanus plumchrus V (Fig. 4).

The copepods were carefulty removed from the storage buckets, filtered onto a section of coarse plankton netting, rinsed several times with filtered seawater and placed in the feeding jars. The particle concentrations were determined with a Coulter Counter using a 100-micron 

apperture tube. A minimum of five counts were made in each jar. The instrumental parameters used to count each phytoplankter are summarized in Table I.

The jars were then strapped to the feeding wheel and rotated at 6 r.p.m. for 22 to 75 hrs at $9 \mathrm{C}$ in the dark. Rotation prevented settling the phytoplankton cells and limited growth of bacteria on the walls of the container (Zobell and Anderson, 1936). In Experiments 2, 4 and 6 the jars were not placed on the feeding wheel but were carefulty inverted once every 10 hours. This eliminated the possibility that rotation might disturb the animals to such an extent as to discourage feeding. The experiments were conducted in the dark to reduce or eliminate phytoplankton cell division and to simulate in situ light regimes of overwintering $\underline{C}$. plumchrus.

At the end of the feeding period, the animals were removed and the final particle concentrations determined. 90-ml aliquots were removed from each of the jars containing copepods, preserved with $10 \mathrm{ml}$ of ethanol and placed in phytoplankton settling chambers. After 48 hours, an inverted microscope was used to search for faecal pellets. Five copepods from each jar were rinsed and dissected for a gut content analysis.

In Experiment 4, chlorophyl1-a analyses were performed to determine if feeding had occurred. 100-ml aliquots from each of the "f.S.W. + phytoplankton" and "f.s.w. + copepods + phytoplankton" jars were filtered onto glass fibre filters and analyzed for chlorophyll-a content.

In Experiments 8 and 10, 01 isthodiscus sp. cells previously killed by freezing were offered as food to both $\underline{C}$. plumchrus and $\underline{C}$. pacificus. The same experimental procedures used with live cells were followed. 

In Experiment 6, cultures in 3 different phases of growth formed the supplied food. "Early log phase" cells were obtained from cultures that had not reached the point of inflection in their growth curve. "Late log phase" cells were collected when the growth rate was beginning to decline after the point of inflection. "Stationary phase" cells were obtained from 3 week old cultures.

Freshly hatched Artemia sp. nauplii were supplied at several concentrations to both $\underline{C}$. plumchrus and $\underline{C}$. pacificus in Experiment $9.800 \mathrm{ml}$ of 0.45 -micron filtered seawater were added to each of the feeding jars and the Artemia introduced. After the contents of the jars had been well mixed, aliquots were removed with volumetric pipettes, passed through grided Millipore filters and the number of Artemia sp. counted. The volume of the aliquots taken varied with the density of Artemia sp. and are listed in Table $X$. Tests showed that random variation among aliquots was less than $10 \%$. It was therefore decided that two aliquots, one removed before and the other after the feeding period, would be sufficient to detect any gross concentration changes. Fifteen copepods were added to each jar. The feeding vessels were stored in the dark for 36 hours after which aliquots were removed, filtered and counted.

\section{Ammonia Excretion}

The ammonia excretion rates of $\underline{C}$. plumchrus $V$ were measured in Experiments 11 and 12. Sixteen liters of 0.45 -micron filtered seawater were well mixed in 5-gallon carboys. $40 \mathrm{mg} / 1$ of streptomycin sulphate and $40 \mathrm{mg} / 1$ of penicillin-G were added to reduce bacterial growth (Butler et al ., 1969). 

In experiment 11 , six $920 \mathrm{ml}$ jars served as controls with no animals added. In the remaining jars, 5, 10, 20, 30, 40,60 or 100 animals were added. Two replicates at each concentration were made. In Experiment 12, six jars were designated as controls with between 18 and 21 animals added to each of the remaining 20 containers.

Care was taken to ensure that exposure of the water to atmospheric ammonia was kept to a minimum. When such exposure was unavoidable, all samples were exposed for an equal duration. Copepods were stored in the dark for a minimum of 7 days prior to the start of each experiment.

After storage in the dark for approximately 30 hours, ammonia concentration in all the jars was determined by the buffered indophenol blue technique developed by Koroleff (1970). The complexing reaction is specific for ammonia and has a useful range of between 0.005 and 100 microgram Atoms per liter (Koroieff, 1970).

Three $60 \mathrm{ml}$ aliquots were removed from each of the jars with a volumetric pipette and placed in $60 \mathrm{ml}$ glass stoppered reagent bottles. $2.0 \mathrm{ml}$ of phenol-sodium nitroprusside solution were added, followed by $2.0 \mathrm{ml}$ of hypochlorite solution (Koroleff, 1970). After mixing, the reagent bottles were stored in the dark for a minimum 12 hour development period. Light absorption was measured in $10 \mathrm{~cm}$ cells at $630 \mathrm{~nm}$ with a Perkin-Elmer (Model 46) spectrophotometer. Calibration standards were prepared by diluting a stock solution of ammonium chioride to produce standard solutions of $0.1,0.2,1.0$ and 2.0 micro-gm atoms $N /$ Titer. $60 \mathrm{ml}$ aliquots of these standards were treated in the same manner as the experimental aliquots and mean calibration constants were calculated from the absorbances. Less than $5 \%$ variability occurred among replicates. 



\section{RESULTS}

\section{A. FIELD SAMPLING}

The vertical distribution of Calanus plumchrus in Saanich Inlet is summarized in Table IV and Figure 5. No animals were observed in the top 75 meters of the water column. $39 \%$ of the total population was below 100 meters with $48.1 \%$ within 25 meters of the bottom.

Physical oceanographic data collected in Saanich Inlet between the months of October and January 1974-75 are summarized in Tables V to VIII and Figures 6 to 10. Oxygen concentrations below 100 meters declined steadily with time.

Anoxic conditions existed in January with only $0.15 \mathrm{ml} / 1$ oxygen present at 150 meters and none detectable at 200 meters. Hoos (1970) similarly reported that "throughout most of the year, the oxygen concentration below 100 meters was less than one milliiiter per liter, and at 175 meters was undetectable." Chlorophyl1-a was never detected below 30 meters. The density structure of the water column as determined by the vertical changes in sigma-t indicated that the water below 75 meters was essentialiy isopycnal during the study period with a small positive density gradient extending to the bottom. By January, all sigma-t values below 75 meters were almost identical.

The physical data from the Strait of Georgia are displayed in Table IX. Unlike Saanich Inlet, the deep waters (400 meters) of the Strait were not oxygen deficient $(3.04 \mathrm{ml} / 1)$. No chlorophyll-a could be detected at 400 meters. 

Microscopic examination of preserved water samples collected from between 75 and 200 meters in the Strait of Georgia indicated the presence of substantial quantities of detritus. Except for the occasional large centric diatom frustulle, no intact phytoplankton cells were observed.

In summary, the majority of the population of $\underline{C}$. plumchrus in Saanich Inlet was restricted to the bottom 100 meters of the water column in isopycnal water that was devoid of oxygen and living plant matter but rich in detritus.

\section{B. LABORATORY EXPERIMENTS}

1. Feeding

All attempts to induce laboratory feeding in $\underline{C}$. plumchrus failed. Seven different phytoplankton cultures representing a wide range of sizes, shapes and taxonomic categories were offered as food. Concentrations and the age of the cultures were varied, as were the copepod densities, the length of each experiment and the duration of prior starvation. Freshly hatched Artemia sp. larvae and dead phytoplankton cells were similarly rejected.

The results of these experiments are listed in Appendix Tables A-I to A-X. No decrease in cell concentrations was observed in any of the "f.s.w. + phytoplankton + copepods" jars. In nearly all cases, a slight increase in particle concentrations occurred. This was attributed to reaggregation of particulate matter (Sheldon et al., 1967) as indicated by small increases in particle counts in the "f.s.w. only" controls and/or the release of particles clinging to the external surfaces of the copepods 

as suggested by slightly increased particle counts in the "f.s.w. + copepods" controls. No faecal pellets were observed in any of the $100 \mathrm{ml}$ aliquots removed from each jar at the termination of the experiment or in aliquots removed following initial capture of the zooplankton. No evidence of recognizable phytoplankton remains were found in any of the dissected copepod guts.

An independent $\underline{t}$-test indicated that there was no significant difference $(P<0.05)$ between the chlorophyll-a concentrations in experimental (f.s.w. + phytoplankton + copepods) jars and control (f.s.w. + phytoplankton) jars. A paired t-test demonstrated that there was no significant difference $(P<0.05)$ between the Artemia $s p$. concentrations before and after the introduction of copepods.

To test the hypothes is that laboratory conditions and experimental procedures were responsible for the lack of feeding, Calanus pacificus was collected and subjected to the same laboratory and experimental conditions as $\underline{C}$. plumchrus. This copepod is morphologically similar to $\underline{C}$. plumchrus, though smaller and with a slightly different life cycle (Brodskii, 1950). Feeding was observed in all seven algae cultures, the Artemia sp. nauplii and the dead phytoplankton cells (Tables $X$ and XI). It was concluded that the absence of feeding in $\underline{C}$. plumchrus was not an artifact of the experimental method.

Ingestion rates for $\underline{C}$. pacificus were calculated using the formula of Esais and Curl (1972):

$$
\text { I.R. }=((C c-C g) V) / N T)
$$

where: I.R. = ingestion rate in cells per copepod per hour 

$C c=$ concentration before feeding $($ ce $11 \mathrm{~s} / \mathrm{ml})$

$\mathrm{Cg}=$ concentration after feeding

$V \quad=$ jar volume in $\mathrm{ml}$

$T \quad=$ time in hours

$N \quad=$ number of copepods in the jar

A11 "before" and "after" concentrations were corrected for changes in the control jars.

The volume of water swept clear by each copepod (the filtration rate) was calculated using the formula of Gauld (1951):

$$
F=V\left(\log \left(C_{0}\right)-\log (C t)\right) /(N t \log (e))
$$

where: $F=$ filtration rate in mls swept clear per day per copepod

$\mathrm{V} \quad=$ volume of jar in $\mathrm{mls}(800 \mathrm{ml})$

Co $=$ concentration before feeding $($ cell $1 \mathrm{~s} / \mathrm{m} 1)$

$C t=$ concentration after feeding (cells/ml)

$t=$ duration of experiment in days

$\mathrm{N}=$ the number of copepods in the jar

The above calculation assumes that the concentration of cells decreases exponentially with time and that $F$ is constant over the period of the experiment. However, it is known that filtering rate $(F)$ varies with cell concentration (Gauld, 1951) so the assumption of a constant filtration rate is only valid for small changes in Co-Ct.

The filtration and ingestion rates and the percent of available phytoplankton removed each day are summarized in Table XII. General trends indicate that smaller phytoplankton cells at higher concentrations were removed faster than larger cells at lower concentrations. 

The ingestion rate of Artemia sp. as a function of the initial Artemia sp. concentration is displayed graphically in Figure 11 . The ingestion rate increased with increasing number of prey and showed no signs of approaching a saturation value.

\section{Ammonia Excretion}

The mean calibration factor determined at each concentration of the standard ammonium chloride solutions and the mean of these $F$ values for both Experiments 11 and 12 are listed in Table XIII. Summaries of the ammonia excretion rates in these two experiments are presented in Tables XIV and XV.

The excretion rates were calculated using the following formula:

$$
E=((A T-A 2)(F)(V)) /(W T)
$$

where: $E$ = mean excretion rate in microgram atoms $\mathrm{N}$ per $\mathrm{mg}$. dry weight per day

$A 1$ = spectrophotometric absorbance of indophenol blue in experimental jars: mean of 3 replicates

$A 2=$ mean absorbance of the 6 control jars

$F=$ mean calibration factor to convert absorbances to concentrations

$V=$ total volume of water $=0.8$ liter

$W=$ total dry weight of copepods in milligrams

$T=$ duration of experiment in days

The excretion rates, expressed as micro-gram atoms $N$ per animal per day, were calculated by multiplying the mean copepod weight per jar by the excretion rate expressed as micro-gm atoms $N$ per mg dry weight per day. 

Days to exhaustion of total body nitrogen were calculated by dividing total body nitrogen by the excretion rate expressed as micro-gm per animal per day. Total body nitrogen was taken to be $7 \%$ of the dry weight (Omori, 1969). For the purposes of this index, it was assumed that there would be no protein uptake from feeding and that $100 \%$ of body nitrogen would be available to metabolism.

The mean excretion rates (with 95\% confidence limits) for Experiment 11 were $15.41 \pm 2.92 \times 10-3$ micro-gm atoms $N$ per mg dry weight per day and for Experiment 12 were $15.33 \pm 0.84 \times 10-3$ micro-gm atoms $N$ per mg dry weight per day. A regression analysis of ammonia excretion on the density of animals in each jar in Experiment 11 indicated that excretion rates did not vary with the number of animals per jar $(P<0.05)$.

C. plumchrus stored in plastic buckets tended to remain vertically oriented in motionless suspension. Observations in a larger 200 1iter container over a 3 -week period confirmed that $\underline{C}$. plumchrus would remain motionless for long periods of time. No movement of feeding or swimming appendages was observed. $\underline{C}$. pacificus, $\underline{\underline{C}}$ glacialis, and $\underline{\underline{C}} \underline{\text { cristatus }}$ under similar circumstances swam constantiy. 



\section{DISCUSSION}

To detect measurable changes in zoologically influenced parameters (e.g., ammonia, oxygen or phytoplankton concentrations) it is often necessary to use zooplankton at concentrations several orders of magnitude greater than in situ levels. In this study, efforts were made to use the lowest concentration of copepods concomitant with the detection limits of the analytical techniques. Hoos (1970) reported a maximum density of $\underline{C}$. plumchrus $V$ in Saanich Inlet of 0.28 copepods/liter. Concentrations of between 6.3 and 125 copepods/liter were used in this research. These densities are significantly higher than in situ levels, but represent a considerable improvement over the densities of between 1000 and 1400 copepods/liter used in some earlier research (Butler et al ., 1969, 1970; Corner et al ., 1965, 1967; Corner and Newe11, 1967).

It is not possible to duplicate the in situ environment in the laboratory. Conditions of light, temperature, oxygen concentration, salinity, etc., can only be approximated to varying degrees. The processes of capture and experimentation may greatly alter a copepod's behavioral and physiological responses. The results of laboratory research must therefore be interpreted in the light of these limitations.

The first adult $\underline{C}$. plumchrus were observed on February 7 in Saanich Inlet. By March 6, all c. plumchrus had molted into the adult stage VI. Camperl (1934) observed that the molt between stage $V$ and adult occurred in early January. Fulton (1973) described the same event as occurring between late December and early February. In both cases, the final molt 

occurred at least one month earlier than was observed during this study. It was unlikely that Littlepage and Rose (1974) were working with $\underline{C}$. plumchrus $V$ during March. Adult females dominate the population at this time of year but do not feed. A similar copepod species, such as $\underline{C}$. glacialis, may have been the animal studied (Littlepage, 1982, pers. comm.).

C. plumchrus $V$ did not feed under laboratory conditions at any time during this study. Feeding experiments were conducted several times each month between September and February with both Artemia sp. and phytoplankton offered as food. Experimental conditions were varied extensively in order to minimize any circumstances that might have discouraged feeding. C. pacificus fed under all experimental conditions. On the basis of these results, it is hypothesized that $\underline{c}$. plumchrus does not feed during the last five months it spends as an overwintering stage $V$ copepodite.

Fulton (1973) proposed a similar hypothesis on the basis of a single 4 day feeding experiment in September, using on ly Artemia sp. and Skeletonema sp. as food sources and on the absence of digested material in the gut of freshly caught and dissected copepods. There was no indication, however, that adequate controls were used to ensure that handling and laboratory conditions were not responsible for lack of feeding. Gut content analyses are not reliable in determining if feeding has occurred because the "trauma" associated with capture often causes violent expulsion of gut contents (Marsha11, 1973). The best evidence for the absence of feeding during winter supplied by Fulton (1973) was of an indirect nature. He demonstrated that $\underline{C}$. plumchrus $V$ could survive for 3.5 months without food in asepticaliy filtered seawater. However, the ability to survive 

without food does not necessarily imply that feeding does not occur in situ.

Gardner (1972) also suggests that $\underline{C}$. plumchrus $V$ does not feed during winter. He states that "the animals (‥ plumchrus) were not fed during the experiment as feeding in the $C-V$ drops off considerabiy in the fall (Gardner, preliminary observations)". Nowhere does he state the nature of these "preliminary observations" and thus critical comments on their validity are not possible.

Zooplankton normally inhabiting a portion of the water column devoid of viable phytoplankton cells may be "acclimated" to feeding on detritus or small zooplankters. Healthy phytoplankton cultures would represent an atypical food at that time of year and may not be consumed. However, during early summer, stage $V$ copepodites do eat large quantities of phytoplankton and there is no morphological evidence suggesting that the ability to filter out algal cells ceases as the animal descends into deeper water. Calanus is a filter feeder and is not able to exercise a great deal of control over the material it captures (Marsha17, 1973). If $\underline{\text { C. plumchrus }}$ does feed on detritus and/or small zooplankton, there is no a priori evidence that it would not eat phytoplankton celis when offered, even though these were absent in the natural environment.

Ammonia excretion rates determined in this study indicate that nitrogen metabolism in $\underline{C}$. plumchrus is very much less than in other overwintering copepods. Less than $0.34 \%$ of the total body nitrogen was excreted daity compared to values of between $1.34 \%$ and $75.5 \%$ described in the 1 iterature (Table XVI). The "days to exhaustion of total body nitrogen" index 

calculated in Table XVI represents an estimate of maximum survival time at the measured excretion rate. This index assumes that nitrogen excretion rates are constant and that protein is not replenished by feeding. Death would occur substantially before $100 \%$ of the body nitrogen had been exhausted.

Conover and Corner (1968) found that overwintering $\underline{\mathrm{C}}$. hyperboreus lost $45 \%$ of total nitrogen between November and March. Assuming these results can be extrapolated to other calanoid copepods, $\underline{C}$. plumchrus could sustain a similar $45 \%$ loss without deleterious effects. Arbitrarily assuming that a further 5\% loss would be fatal, between 165 and 183 days would be required for $\underline{C}$. plumchrus to sustain a critical $50 \%$ loss of nitrogen. It is evident that $\underline{C}$. plumchrus has sufficient protein reserves to sustain the animal at the observed rates of nitrogen metabolism for several months without replenishment from external sources.

Integration of data from this study and from previous published literature has led to the hypothesis that the metabolic rate of overwintering C. plumchrus in Saanich Inlet is substantialiy lower than that reported for other species of Calanus. The concept of "hibernation" or "diapause" as originally discussed by Marshall and Orr (1958) and the attendant reductions in all aspects of metabolism is suggested as an adaptive solution to the problem of overwintering nutrition. The following is a summary of the evidence used to arrive at this conclusion.

Corner et al. (1974) demonstrated that active carnivory was the only form of nutrition capable of sustaining nitrogen and phosphorus levels in overwintering Calanus. If overwintering $\underline{C}$. plumchrus $V$ has metabolic 

requirements similar to those of $\underline{\underline{C}}$. helgolandicus, carnivorous feeding would be the expected mode of nutrition. $\underline{C}$. plumchrus $V$ would not ingest Artemia sp. nauplii, which are actively eaten by most calanoid copepods (Mullin, 1966: Marsha11, 1973). The absence of feeding in overwintering C. plumchrus $V$ and its requirement in $\underline{C}$. finmarchicus and $\underline{C}$. helgolandicus (Corner et al., 1974) constitutes indirect evidence that the metabolic rate of the former species must be lower than that of the latter.

Evidence for a greatly reduced metabolic rate can be inferred directly from data concerning lipid reserves and nitrogen excretion. Lipid metabolism in $\underline{C}$. plumchrus is very low, as demonstrated by the retention of from $50 \%$ to $60 \%(0.47-0.47 \mathrm{mg})$ of $i$ ts total body weight as lipid throughout the overwintering period (Lee, 1971).

Nitrogen excretion data indicate that protein metabolism in $\underline{C}$. plumchrus $V$ is at least an order of magnitude lower than that reported for other overwintering copepods. Calculations based on the observed ammonia excretion rates suggested that $\underline{C}$. plumchrus $V$ would not exhaust body protein during 6 months of starvation. This conclusion was confirmed by Fulton (1973) who demonstrated that $\underline{c}$. plumchrus $V$ could survive 3.5 months of starvation and then molt successfully into the adult. Overwintering $\underline{C}$. helgolandicus suffered losses of $20 \%$ and $22 \%$ of body nitrogen and phosphorus respectively after only 5 days without food (Corner et al., 1974).

0xygen concentrations in the deeper water of Saanich Inlet steadily declined during the winter until essentially anoxic conditions existed below 150 meters by January (Table VIII, Fig. 10). Approximately 55\% of the $\underline{C}$. plumchrus $V$ population resided in this oxygen minimum layer (Fig. 5). 

Aerobic metabolism would of necessity be at very low levels. The deep waters of the Strait of Georgia were not oxygen deficient (Table IX) and metabolic rates would not be limited by the in situ oxygen concentration.

The observation that $\underline{C}$. plumchrus $V$ remained suspended in the water column, motionless, may suggest energy conservation. All other copepods subjected to similar circumstances exhibited continuous swimming. The large lipid sac in $\underline{C}$. plumchrus $V$ may serve as a flotation device.

According to Mansingh (1971) diapause is the most highly evolved system of dormancy able to overcome cyclic, long-term and extreme environmental conditions. However, diapause has until recently only been used in reference to insect overwintering strategies. Elgmork and Nilssen (1978) made a detailed comparison between the sequential stages of insect diapause and the dormant stages of fresh water cyclopoids which bury themselves in the bottom sediment before the lake freezes over. They concluded that the two overwintering processes were physiologically equivalent. The biochemical link between insect diapause and the physiological state of overwintering marine copepods was established by Hirche (1978). He could not detect any trypsine (a digestive enzyme) activity in overwintering calanoid copepods (species not identified) in a Swedish fjord. Amylase activity was at a very low level. Microscopic examination of the mid-gut epithelium showed strongly reduced microvilli (Hallberg and Hirche, 1980). Hirche concluded that these copepods were unable to digest food. He also observed that overwintering copepodite stage $V$ 's retained in the laboratory were floating motionless with their antennae stretched backwards along the body, an observation which matches the laboratory behavior of $\underline{C}$. plumchrus. 

Copepods from the Swedish fjord did not produce faecal pellets and would not feed on algae cultures of Thalassiosira fluviatilis and Scripsiella faroensis (Hirche, 1978). Hirche concluded that these copepods survived the low food conditions present in the fjord during winter by entering into a dormant state virtually identical to insect diapause. These conclusions were reiterated in 1980 by Hallberg and Hirche working on overwintering $\underline{\mathrm{C}}$. finmarchicus and $\underline{\mathrm{C}}$. helgolandicus captured from another Swedish fjord. They observed a very much reduced mid-gut epithelium associated with very low digestive enzyme activity. Again, diapause was offered as an explanation.

It would appear from the results of this study that Calanus plumchrus has also met the challenge of low winter food levels by adopting a dormant physiological state very similar to insect diapause. This conclusion supports earlier speculation by Gardner (1972) who first suggested that the behavioral pattern of $\underline{\mathcal{C}}$. plumchrus could be described in terms of a diapause. He used Hoar's (1966) rather broad definition of diapause as a "condition characterized by an abrupt onset of dormancy, followed by resumption of growth and terminating in metamorphosis, rapid growth or reproductive activity". Gardner (1972) did not investigate the extent or physiological nature of this overwintering dormancy. He did suggest that C. plumchrus would derive a considerable energy bonus by feeding in nearsurface waters during early summer and then descending to deeper, cooler waters to assimilate the food and to rest during the fall and winter period. The concept of diel and seasonal vertical migration serving as an energy conservation mechanism was first proposed by McLaren (1963) to 

explain why the deep scattering layer frequently migrates towards the surface at night and descends to depth by day.

In recent years, a substantial amount of research has been conducted into the biology of the zooplankton that inhabit the extensive oxygen minimum zones that exist in most of the world's oceans at intermediate depths. A large, permanent oxygen minimum layer exists in the Northern Pacific Ocean between $5 \mathrm{~N}$ and Alaska and at depths ranging from 100m to 2000m (Dietrich et al., 1975). The geographical range of $\underline{\text {. }}$ plumchrus also includes the North Pacific (north of $40 \mathrm{~N}$ ) but an extensive literature search indicates that it has not been found in the oxygen minimum layer.

Longhurst (1967) found that the zooplankton in the Eastern Pacific oxygen minimum layer off Mexico was dominated by the resting stage $V$ copepodites of $\underline{\mathrm{C}}$. helgolandicus (= pacificus). He suggested that oxygen deficient layers were suitable locations for resting stocks owing to their low temperatures which would "favor the low metabolic rate presumably needed to over-winter for a period of more than six months."

Judkins (1980) reported half a dozen different species of calanoid copepod residing in the oxygen minimum layer off Peru. Species found included $\underline{\mathrm{C}}$. chilensis, Eucalunus inermis, and Paracalanus parvus.

Childress (1968 and 1975) measured the oxygen consumption rates of 28 species of midwater crustaceans including four copepods that lived in low oxygen layers off southern California. He discovered that most of the species examined could maintain a constant oxygen consumption rate over a broad range of ambient oxygen partial pressures down to the lowest 

pressure to which they were usually exposed in their natural habitat. He suggested that anaerobic metabolism would be very unlikely because the food level in an oxygen minimum layer "is apparently too low to allow animals to live actively, hunt food, grow and reproduce using the low energy yield of anaerobic metabolism". Childress (1975) concluded that the majority of zooplankton living in oxygen minimum zones do so aerobicalty.

The research of Longhurst, Judkins and Childress demonstrates that calanoid copepods can and do thrive at very low oxygen levels. The relative absence in the literature of references to $\underline{C}$. plumchrus living in oxygen minimum zones may be attributable to a lack of concurrent zooplankton and oxygen sampling at intermediate depths (down to $2000 \mathrm{~m}$ ) in the North Pacific. All of the above researchers did their sampling south of $\underline{C}$. plumchrus's range. Alternatively, it may be possible that $\underline{\mathcal{C}}$. plumchrus simply does not inhabit the North Pacific oxygen minimum zone.

My experimental results indicate that $\underline{\underline{C}}$. plumchrus is fully adapted to life at low oxygen levels. However, my study was conducted in a restricted basin (Saanich Inlet) which has a transitory oxygen minimum zone. In contrast, the oxygen minima in the subtropical Pacific are large scale and permanent features. Devol (1981) investigated zooplankton respiration rates in two British Columbia fjords (Saanich and Princess Louise Inlets) which both have transitory oxygen minimum zones. In sharp contrast to the abundance of life found in open ocean minima, he discovered virtually no zooplankton of any kind inhabiting the oxygen minimum zone. Specifically, he found the majority of the zooplankton, 

including $\underline{C}$. plumchrus hovering in the oxycline immediately above the oxygen minimum. Devol explained this important difference in terms of the long term stability of open ocean oxygen minima providing a constant environment for the evolution of unique aerobic respiration mechanisms. This is contrasted by the isolated and transient nature of low oxygen zones in largely enclosed basins which would require an organism to deal with drastic seasonal changes in oxygen concentration. Devol suggests that few organisms have evolved a physiology capable of dealing with this harsh environment.

Devol's (1981) results appear to contradict my findings in that he did not observe $\underline{C}$. plumchrus in Saanich Inlet inhabiting the oxygen minimum zone. However, Devol conducted his sampling in April, June, and July while mine was done in October through January. Based on the observations presented in this thesis, I would suggest that $\underline{C}$. plumchrus migrates into the oxygen minimum zone sometime during the August to September time-frame, which is the interval separating Devol's and my sampling periods. This is in keeping with the generally accepted life cycle of $\underline{c}$. plumchrus as reviewed earlier in this paper.

Fjords present several unique acoustic forecasting problems related to the great temporal and spatial variability in their physical oceanography. Heavy winter precipitation and highly seasonal river runoff combine to produce large scale changes in the sound speed profile. Many basins, including Saanich Inlet, undergo a dramatic "flushing" in the fall when the physical properties of the water change substantially in a few weeks. Man-made sources of ambient noise are frequent and of 

relatively high intensity. The biological contributions to both ambient noise and sonic scattering are also much more variable and hence, less predictable, than in the open ocean.

Acoustical transmission loss prediction models which are valid in highly convoluted coastal regions (e.g., British Columbia and the NATO Northern flank) must take into account the seasonal variation in biological scattering. $\underline{C}$. plumchrus constitutes one of the single largest components of zooplankton biomass in B.C. coastal waters and, as such, is an important source of high frequency ( $60 \mathrm{KHZ}$ and up) sonic scattering. The seasonal change in vertical distribution and population density of c. plumchrus has a substantial impact on sonic scattering intensities. The population is concentrated in surface waters during the spring and early summer and in deep water during winter. Oxygen minimum layers present during winter in many B.C. coastal fjords seem to offer a particulariy attractive habitat.

High frequency mine counter-measures sonars and acoustic homing torpedos operating in surface waters during summer will be influenced by the strong $\underline{C}$. plumchrus induced volume reverberation and scattering. Deep running torpedos and variable-depth minehunting sonars operating in the oxygen minimum layers will also experience back scattering from $\underline{C}$. plumchrus. Dense copepod aggregations attract large schools of fish, notably the Pacific saimon, which make a very substantial contribution to volume reverberation and backscattering in the 2-20 $\mathrm{KHZ}$ range (Urick, 1975). Most navai search and attack sonars operate at these frequencies and thus, indirectiy, are affected by the seasonal distribution of $\underline{c}$. piumchrus. 

Bottom deployed acoustic torpedo "mines" would also be influenced by copepod scattering. The USN CAPTOR system (enCAPsulated TORpedo) is designed to be deployed on the bottom of a strategically important strait and consists of an encapsulated MK 46 torpedo and both active and passive sonar detection systems (Janẻs Weapons Systems, 1981-82). The torpedo is automatically launched upon detection of an enemy submarine. If such a system were to be deployed in a British Columbia fjord, its operational depth could coincide with the winter oxygen minimum layer and its accompanying population of $\underline{\mathrm{C}}$. plumchrus.

All acoustical forecasting schemes involve solving the sonar equation. Components of the active sonar equation include biologically induced transmission loss and volume reverberation. Future research in this field should be directed towards specifically measuring copepod induced sonic scattering and reverberation in coastal waters with the aim of forecasting scattering and reverberation levels with variable geographical location, season and depth. The predicted levels could then be fed into the sonar equation to produce better estimates of operational sonar detection ranges. 



\section{SUMMARY}

1. A study was initiated into the feeding behaviour and excretion physiology of the stage $V$ copepodite of Calanus plumchrus in Saanich Inlet with the goal of formulating a hypothesis on the nature of overwintering nutrition.

2. In December, no $\underline{C}$. plumchrus $V$ were observed above $75 \mathrm{~m} ; 48 \%$ of the total population were within $25 \mathrm{~m}$ of the bottom of the Inlet.

3. Oxygen concentrations below 75 meters in Saanich Inlet declined steadily during the winter months; by January, anoxic conditions existed from $150 \mathrm{~m}$ to the bottom.

4. No chlorophyll-a could be detected below 30m.

5. All attempts to induce feeding in $\underline{C}$. plumchrus under laboratory conditions failed. Feeding was demonstrated in $\underline{\underline{C}}$. pacificus under similar conditions and it was concluded that $\underline{C}$. plumchrus $V$ did not feed in situ during the winter.

6. Nitrogen excretion in $\underline{C}$. plumchrus was measured with the ammonia detection technique of Koroleff (1970). The mean excretion rates in the two experiments were: $15.4 \times 10-3$ and $15.3 \times 10-3$ micro-gm atoms of nitrogen per mg dry weight per day.

7. The nitrogen excretion rates were 10-20 times lower than those previously reported for calanoid copepods.

8. It was calculated that $\underline{\underline{C}}$. plumchrus had sufficient body protein to sustain itself at the observed nitrogen excretion rates for a minimum of 5 months. 

9. Laboratory observations of the behaviour of $\underline{\mathcal{C}}$. plumchrus in large volumes of water indicate that this copepod may of ten be suspended motionless in the water column.

10. It was hypothesized that $\underline{C}$. plumchrus $V$ meets the problem of reduced winter food levels by entering a state of "quasi-hibernation" or diapause characterized by a reduction of al1 metabolic functions.

11. C. plumchrus is a significant source of high frequency sonic scattering. Predicting zooplankton scattering intensity as a function of season, geographical location and depth is an important goal in acoustic forecasting. A significant step towards attaining this capability would be to conduct extensive temporal and spatial field measurements of copepod scattering and reverberation in coastal waters. 



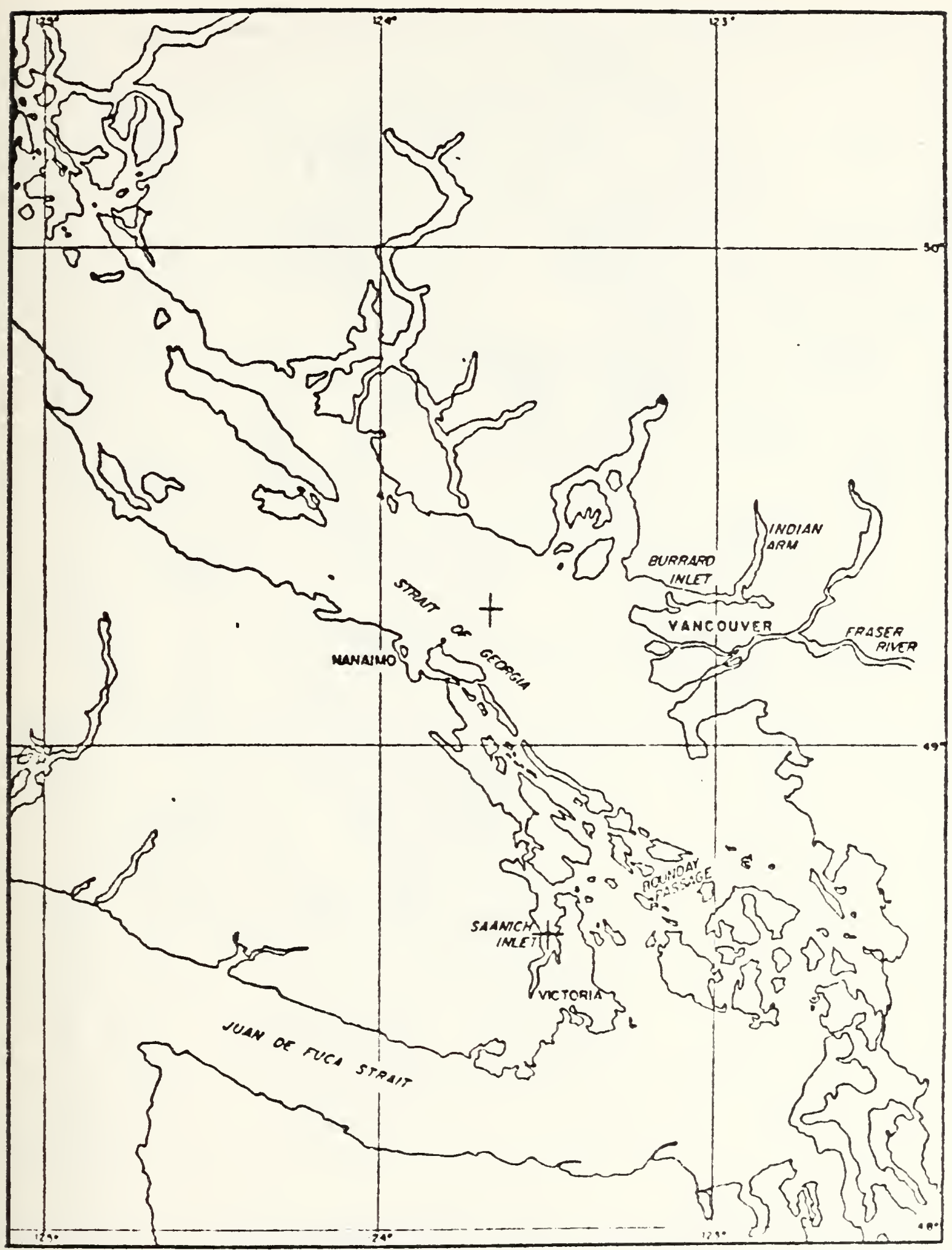

Figure 1. Map showing location of the two sampling stations ( + ) 



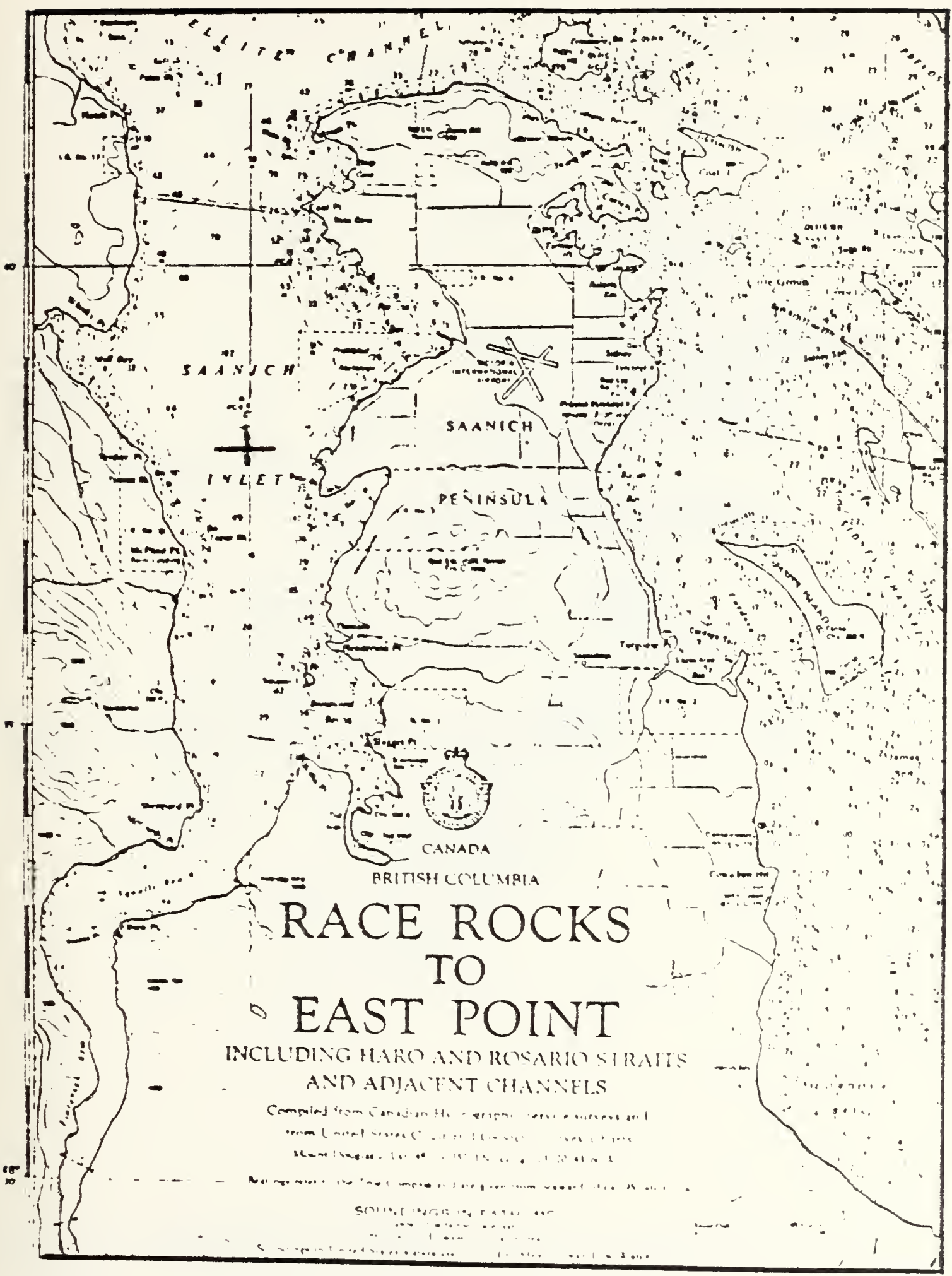

Figure 2. Chart showing location of Station $E$ in Saanich Inlet (t) 



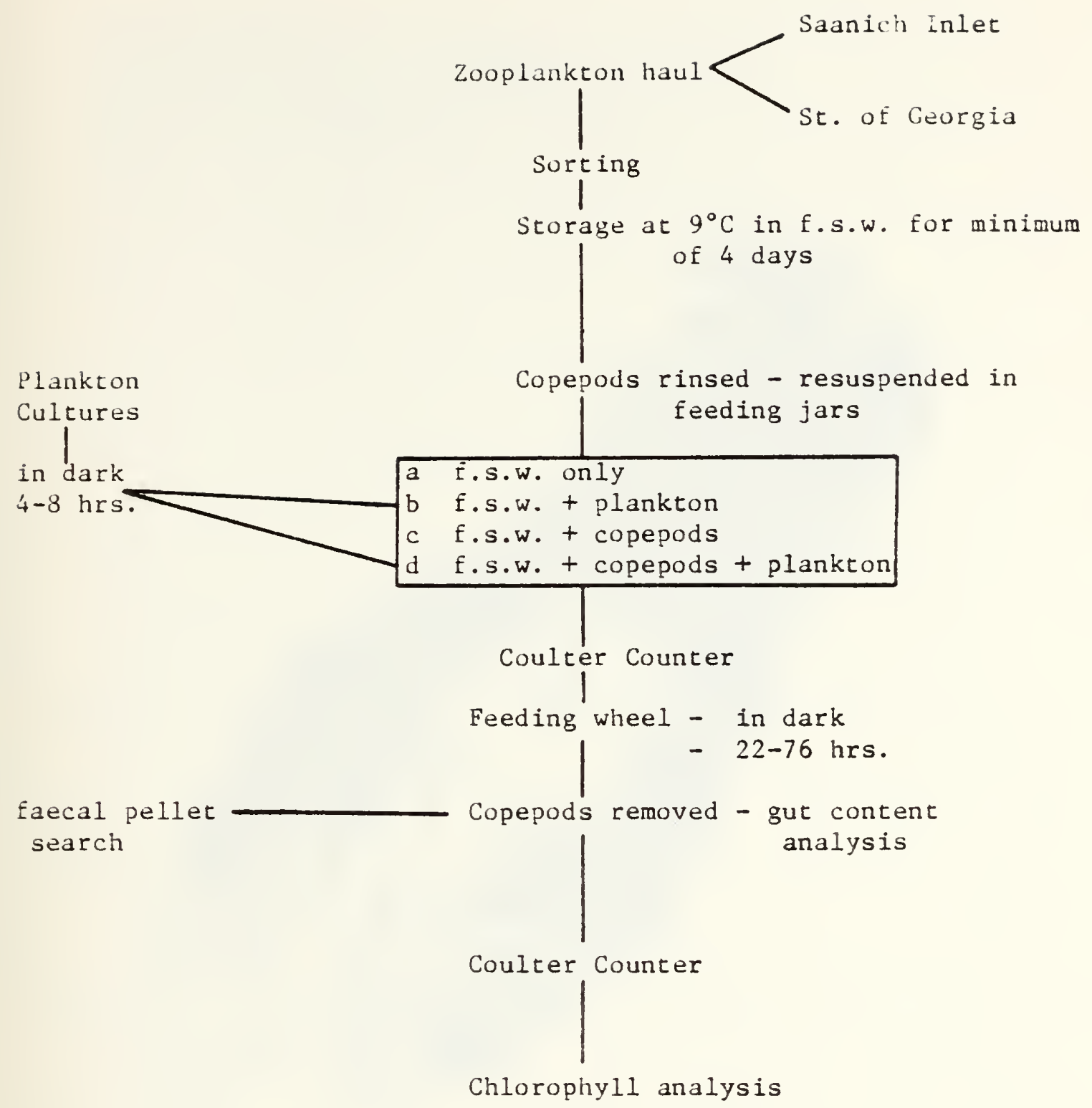

Figure 3. Experimental flowchart 



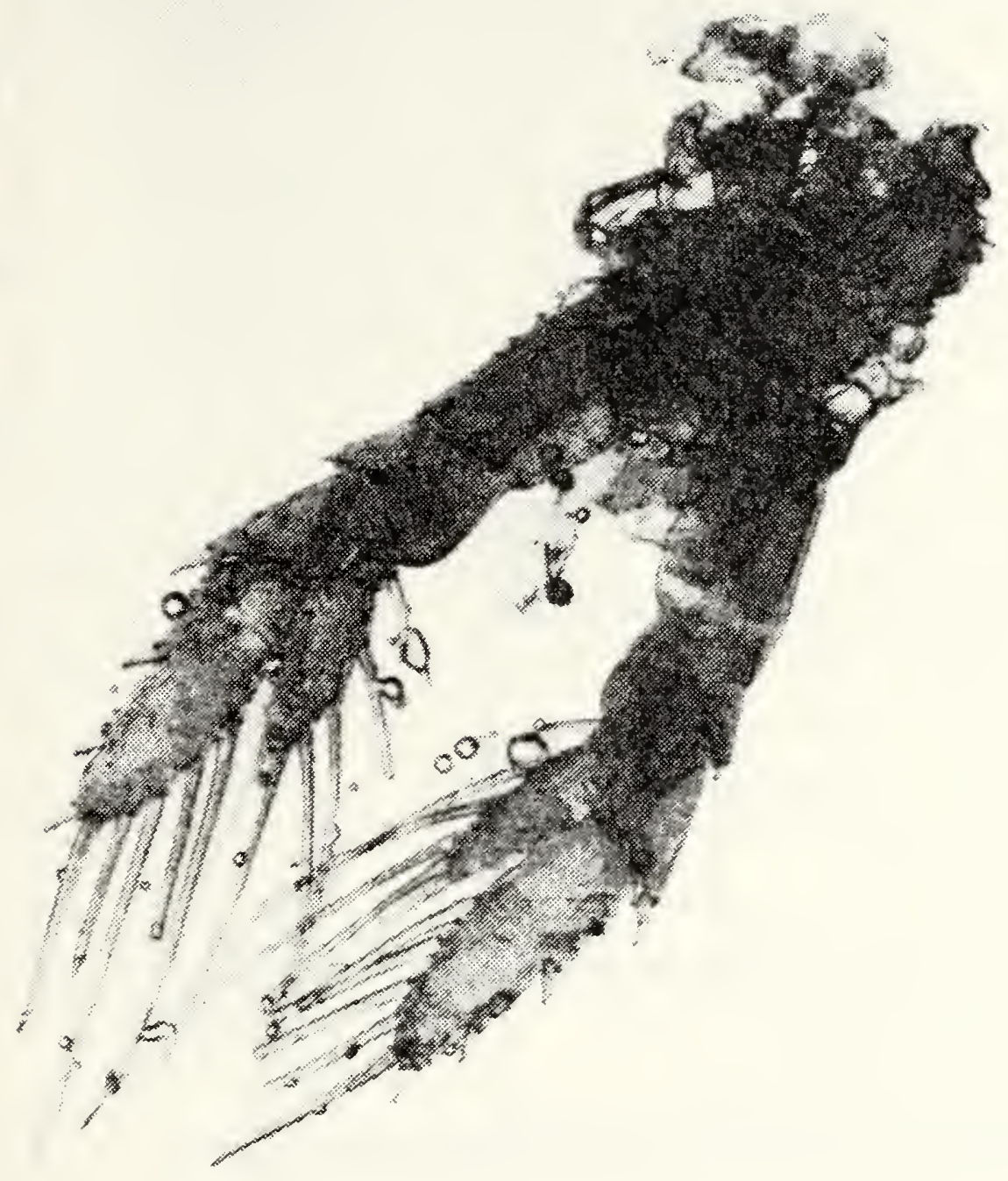

Figure 4. Representative fifth leg of Calanus plumchrus $V$. 

Figure 5. The vertical distribution of Calanus plumchrus in Saanich Inlet at $1300 \mathrm{hrs}$, December 19, 1974. "Percent" refers to the percentage of the total $\underline{\mathrm{C}}$. plumchrus $\mathrm{V}$ in the water column present in each $25 \mathrm{~m}$ interval.

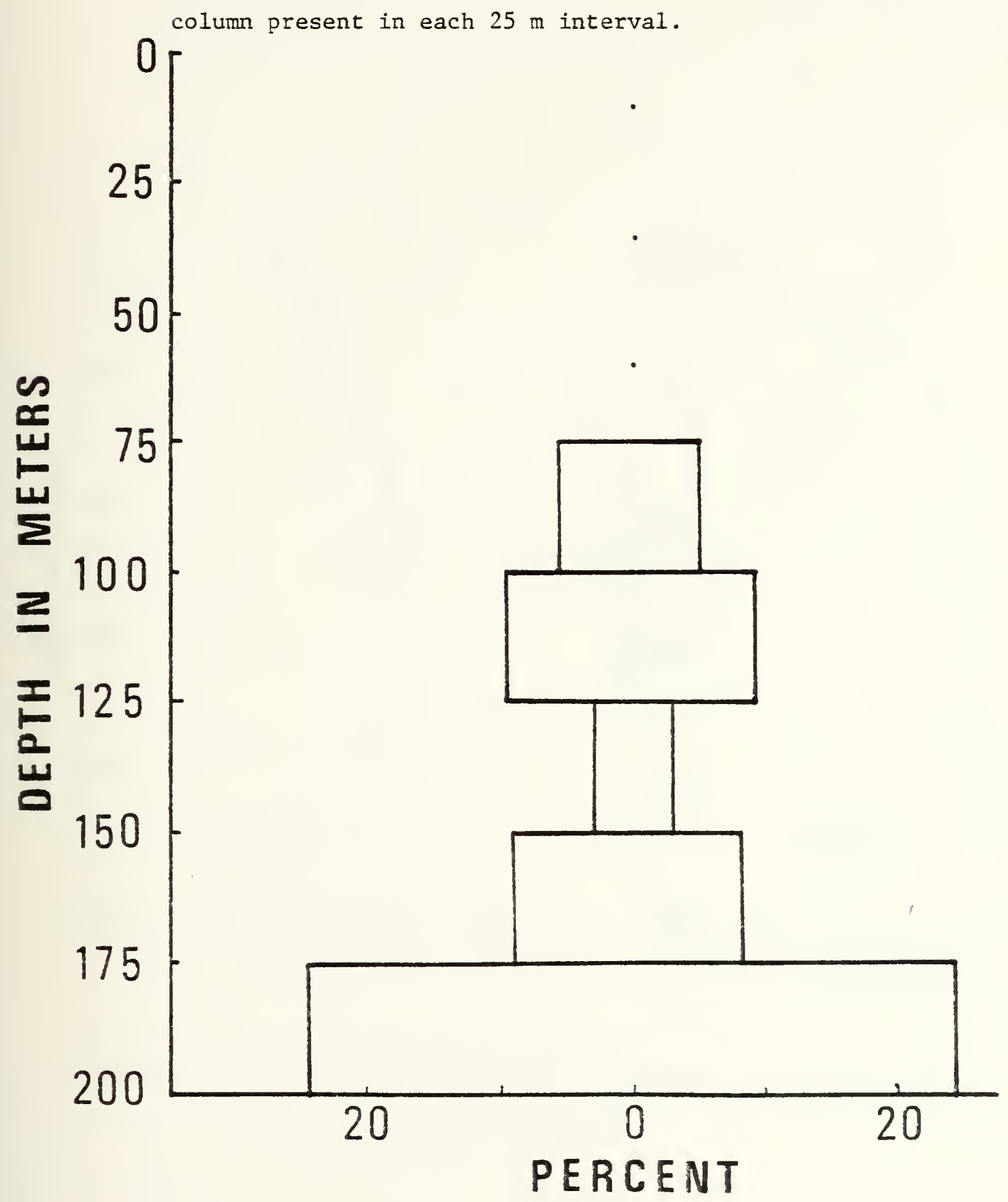




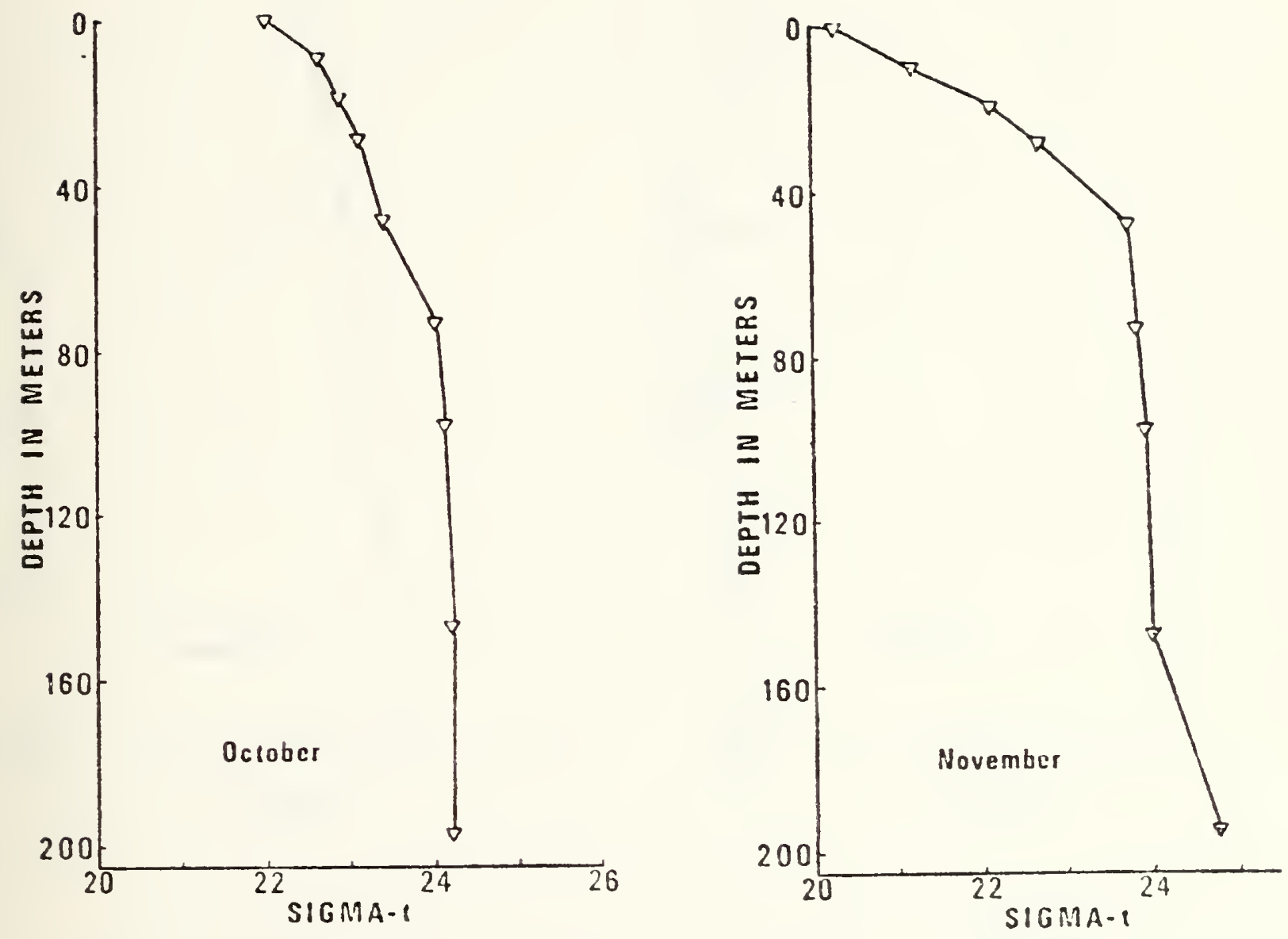

Figure 6. The vertical distribution of Sigma-t in Saanich Inlet during October and November. 


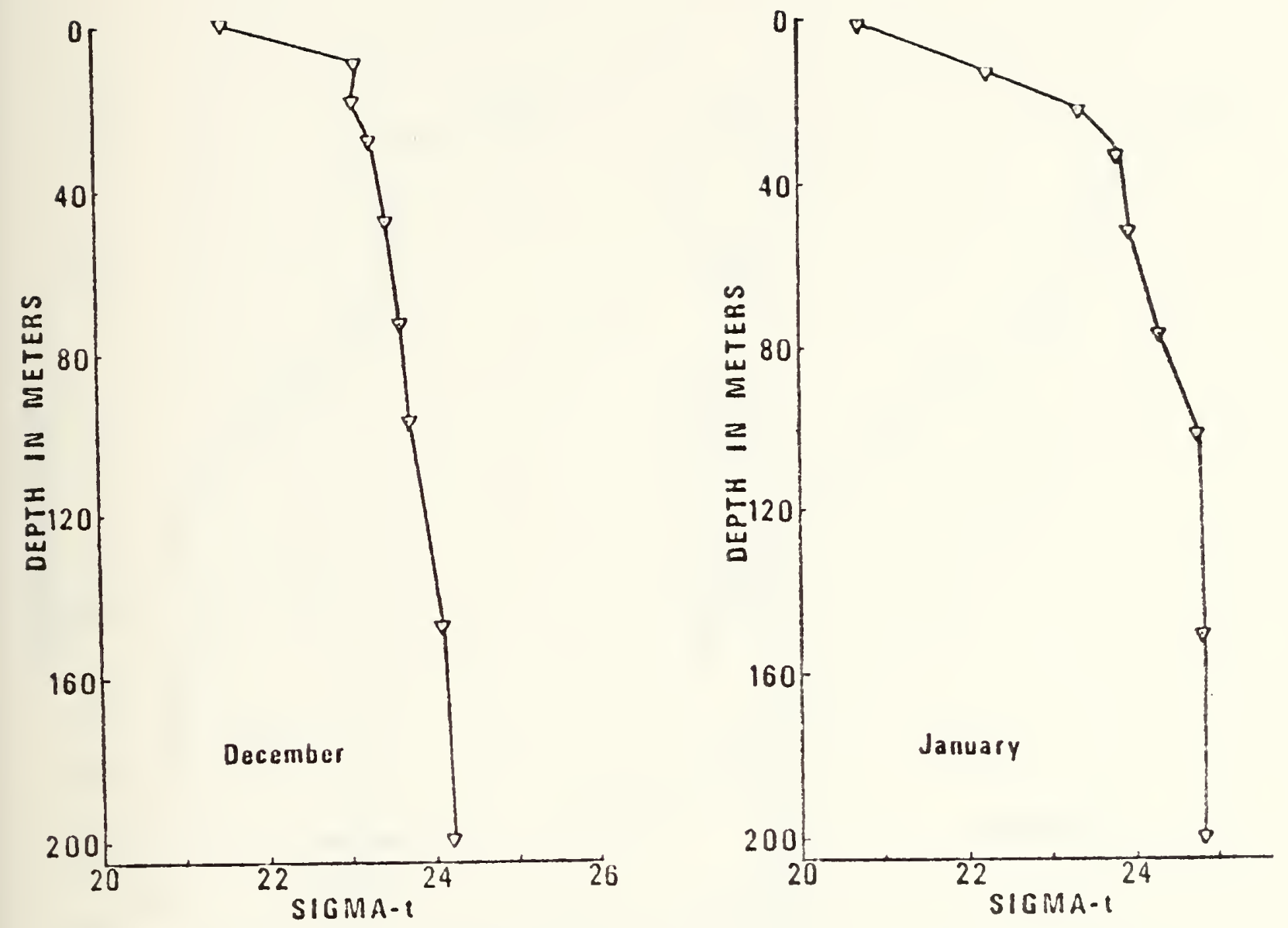

Figure 7. The vertical distribution of Sigma-t in Saanich Inlet during December and January. 


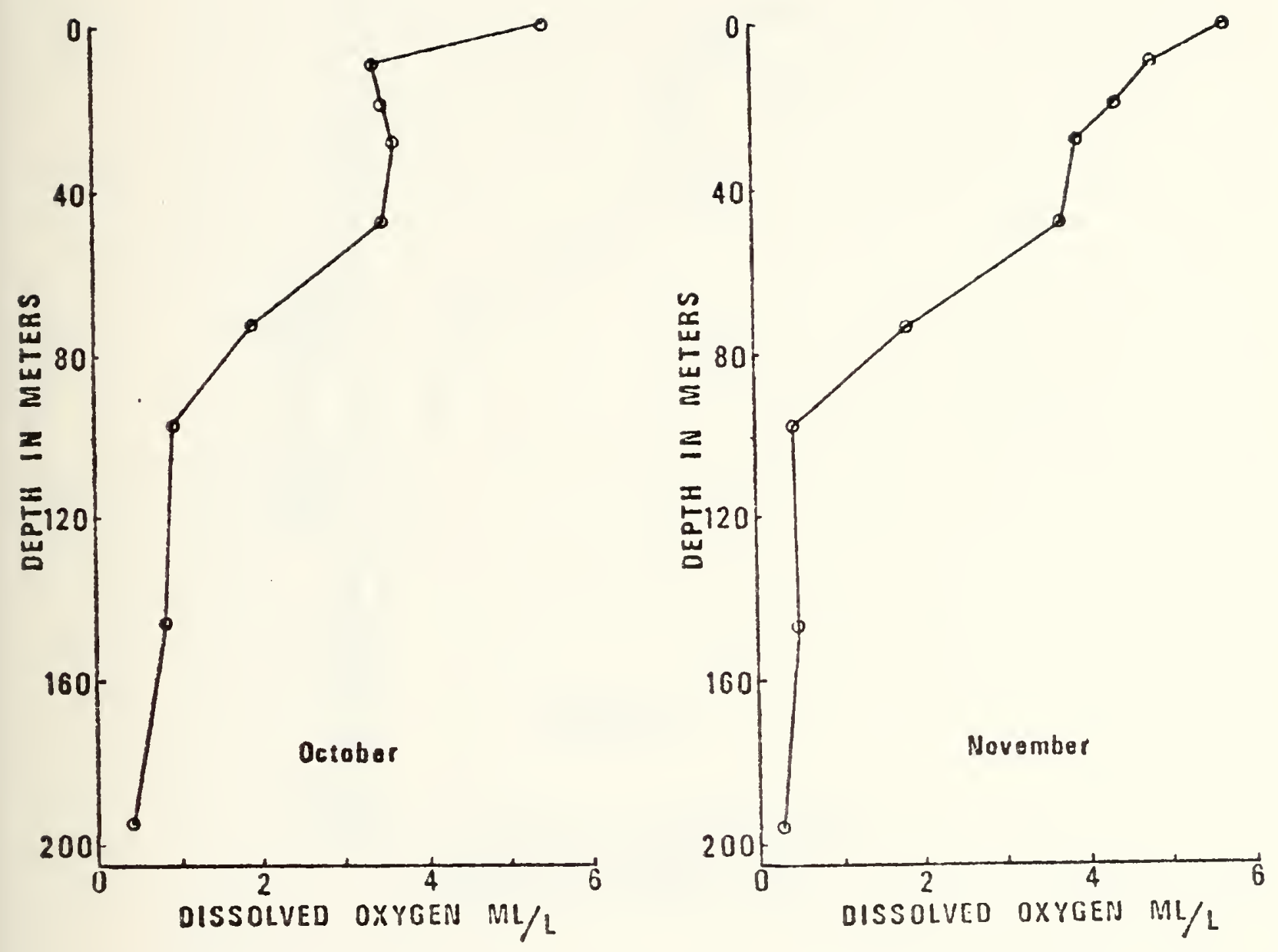

Figure 8. The vertical distribution of dissolved oxygen in Saanich Inlet during October and November. 



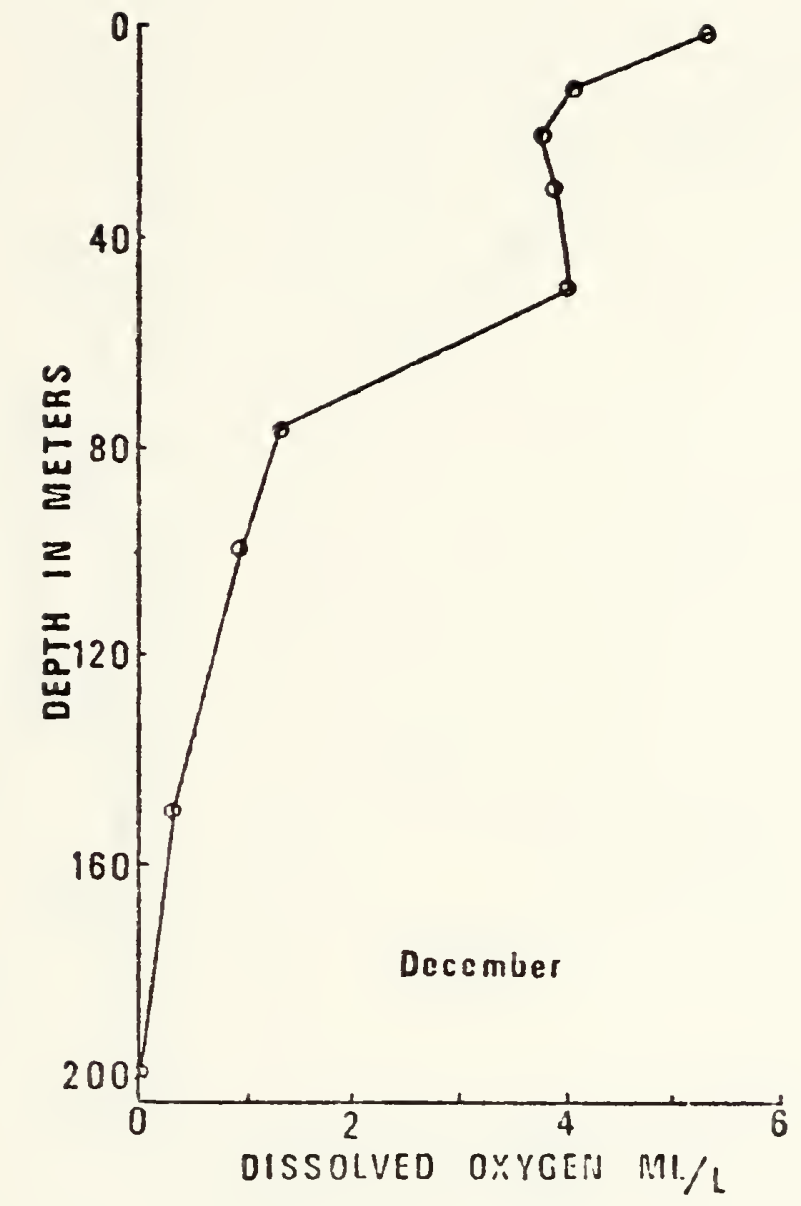

Figure 9. The vertical distribution of dissolved oxygen in Saanich Inlet during December. 



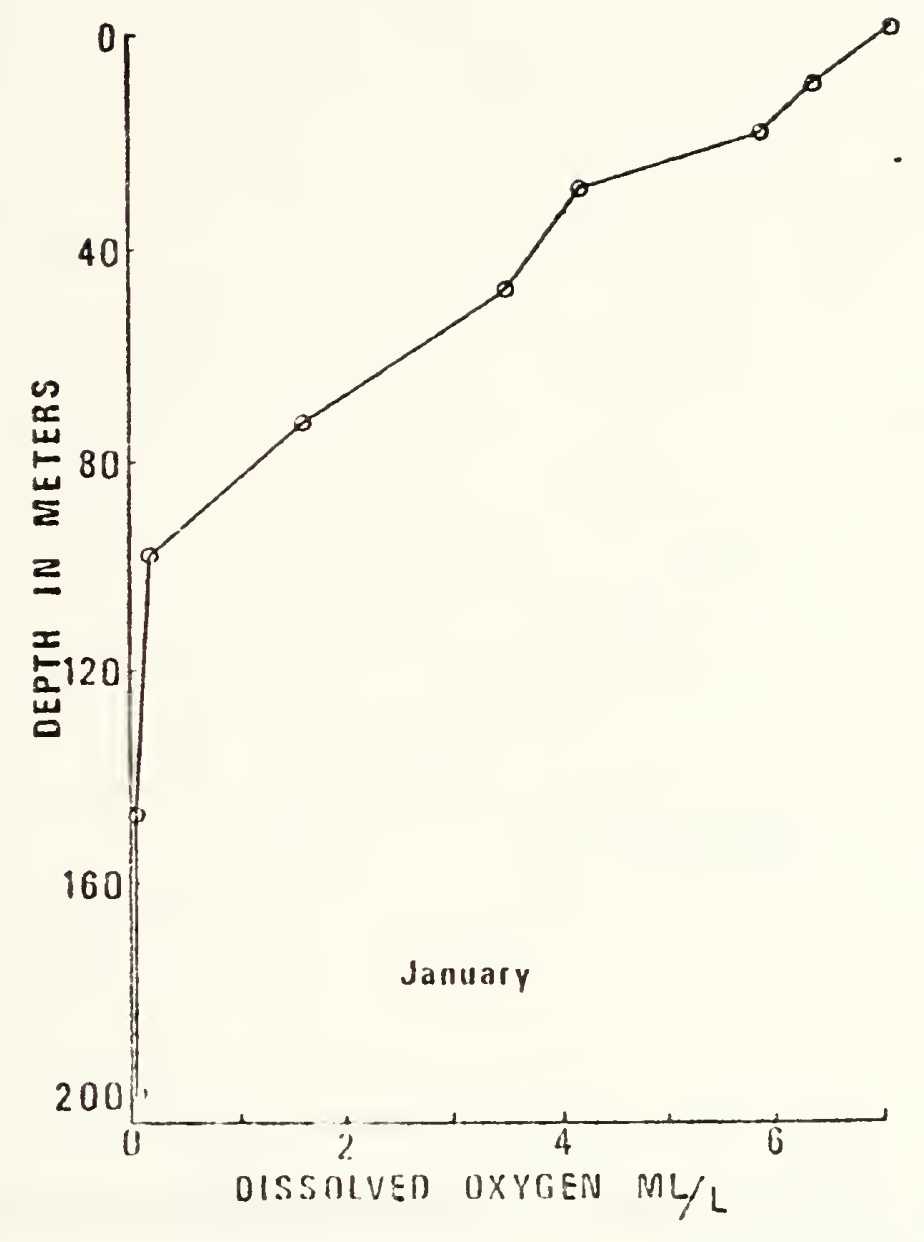

Figure 10. The vertical distribution of dissolved oxygen in Saanich Inlet during January. 



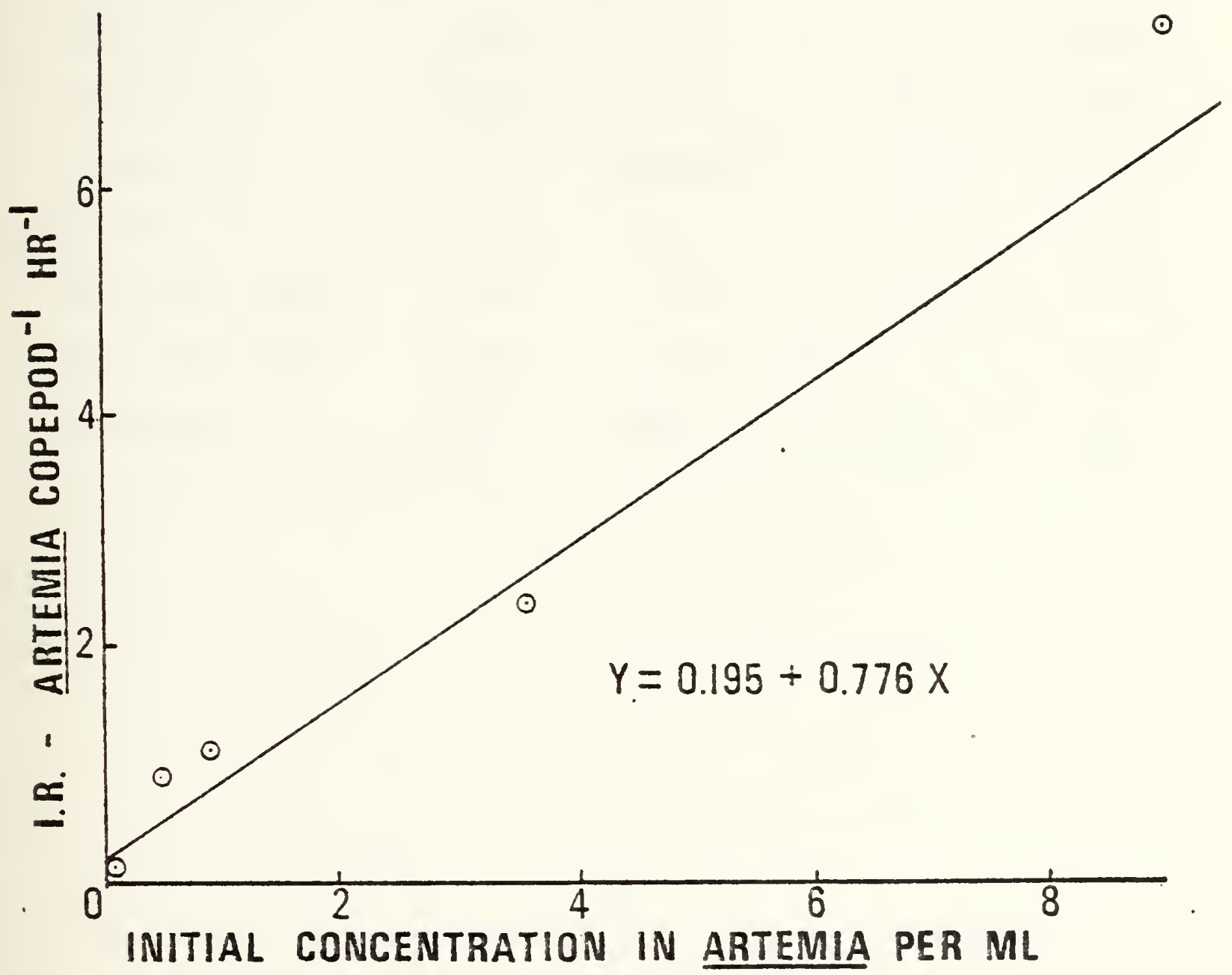

Figure 11. Regression of mean $\underline{\text {. pacificus }}$ ingestion rate (I.R.) on initial Artemia sp. concentration. 

TABLE I. Phytoplankton Dimensions and the Coulter Counter Parameters Used to Determine Phytoplankton Concentrations

\begin{tabular}{lcccc}
\hline Culture & $\begin{array}{c}\text { Length } \\
\text { (microns) }\end{array}$ & $\begin{array}{c}\text { Width } \\
\text { (microns) }\end{array}$ & Sensitivity & Thresholds \\
\hline $\begin{array}{l}\text { Thalassiosira } \\
\text { fluviatilis } \\
\text { Nitzschia sp. }\end{array}$ & $15-20$ & 10 & 1 & $20-100$ \\
$\begin{array}{l}\text { Isochrysis sp. } \\
\text { Peridinium sp. }\end{array}$ & $22-30$ & $5-6$ & 0.25 & $20-100$ \\
Chroomonas salina & $20-25$ & $15-20$ & 0.0825 & $20-100$ \\
OZisthodiscus sp. & $12-15$ & $8-10$ & 2.8 & $20-100$ \\
Cymbomonas sp. & $20-25$ & spherical & 0.25 & $15-100$ \\
\hline
\end{tabular}





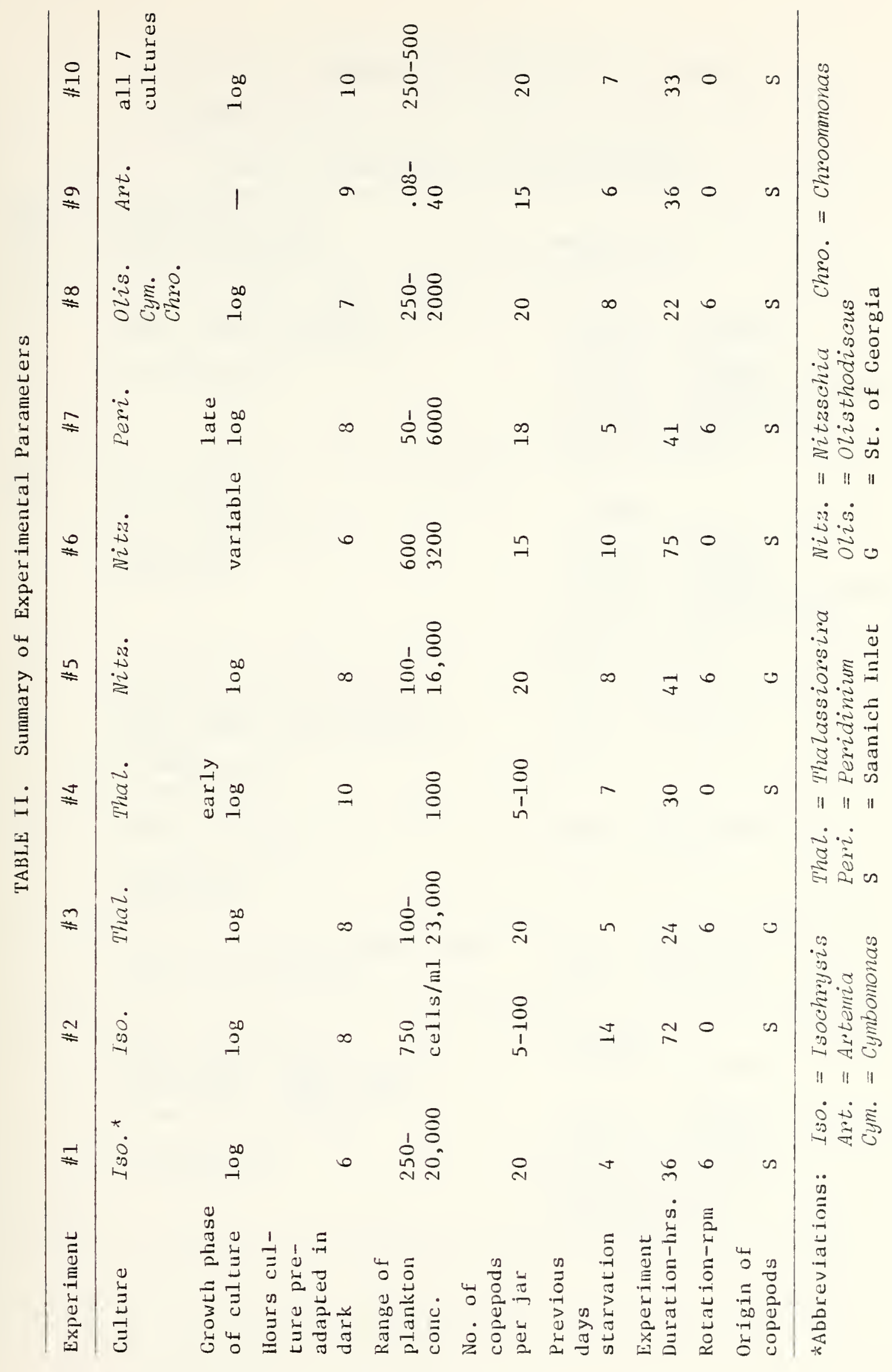



TABLE III. Summary of the Experimental Design:

Plankton Concentrations, Copepod Densities, and

Number of Replicates in Each Experiment

\begin{tabular}{|c|c|c|}
\hline $\begin{array}{l}\text { Exp't } \\
\text { No. }\end{array}$ & $\begin{array}{l}\text { Phytoplankton and } \\
\text { Copepod Densities }\end{array}$ & Replicates \\
\hline 非1 & $\begin{array}{l}250,700,1400,2000,4400 \\
8200,20,000 \text { cells/mi. } \\
20 \text { animals/jar }\end{array}$ & $\begin{array}{l}2 \text { blanks } \\
3 \text { water + copepods } \\
1 \text { water + plankton } \\
2 \text { water + plankton + copepods } \\
\text { for each concentration } \\
\text { total }=26 \text { jars }\end{array}$ \\
\hline 非 2 & $\begin{array}{l}750 \text { cells/m1 } \\
5,10,20,50,100 \\
\text { animals/jar }\end{array}$ & $\begin{array}{l}2 \text { blanks } \\
1 \text { water + copepods } \\
1 \text { water + plankton } \\
1 \text { water }+ \text { plankton }+ \text { copepods } \\
\text { for each concentration } \\
\text { total }=22 \text { jars }\end{array}$ \\
\hline$\# 3$ & $\begin{array}{l}100,200,400,800,1600 \\
3400,6800,23,000 \mathrm{ce} 11 \mathrm{~s} / \mathrm{ml} \\
20 \text { animals/jar }\end{array}$ & $\begin{array}{l}\text { same as Experiment }-1 \\
\text { total }=29 \text { jars }\end{array}$ \\
\hline 非4 & $\begin{array}{l}1000 \text { cells/ml. } \\
5,10,20,50,100 \\
\text { animals/jar }\end{array}$ & $\begin{array}{l}\text { same as Experiment }-2 \\
\text { total }=23 \text { jars }\end{array}$ \\
\hline ik 5 & $\begin{array}{l}100,200,400,800,1800,3200 \\
7400,16,000 \mathrm{cel} 1 \mathrm{~s} / \mathrm{m} 1 .\end{array}$ & $\begin{array}{l}\text { same as Experiment }-1 \\
\text { total }=29 \text { jars }\end{array}$ \\
\hline 非 6 & $\begin{array}{l}600,3200 \text { cells/ml. } \\
\text { "early log," "late log" and } \\
\text { "stationary" phase cells } \\
\text { at each concentration } \\
15 \text { animals/jar }\end{array}$ & $\begin{array}{l}3 \text { blanks } \\
3 \text { water + copepods } \\
1 \text { water + plankton } \\
2 \text { water + plankton + copepods } \\
\text { for each of the } 3 \\
\text { cell ages at the } 2 \\
\text { concentrations }\end{array}$ \\
\hline
\end{tabular}



TABLE III. Continued

\begin{tabular}{|c|c|c|}
\hline $\begin{array}{l}\text { Exp't } \\
\text { No. }\end{array}$ & $\begin{array}{l}\text { Phytoplankton and } \\
\text { Copepod Densities }\end{array}$ & Replicates \\
\hline 非 & $\begin{array}{l}50,100,200,500,1000,3000 \\
6000 \mathrm{cells} / \mathrm{ml} . \\
18 \text { animals/jar }\end{array}$ & $\begin{array}{l}\text { same as Experiment }-1 \\
\text { total }=26 \text { jars }\end{array}$ \\
\hline$\# 8$ & $\begin{array}{l}\text { Chroomonas: } 500,2000 \text { cells/ml. } \\
\text { Olisthodiscus: } 300,1600 \\
\text { Cymbomonas: } 300,1800 \\
\text { frozen Olisthodiscus } 2000 \\
20 \text { animals/jar }\end{array}$ & $\begin{array}{l}1 \text { water + copepods } \\
1 \text { water + plankton } \\
2 \text { water + plankton + copepods } \\
\text { for each concentration } \\
\text { total }=28 \text { jars }\end{array}$ \\
\hline$\$ 99-A$ & $\begin{array}{l}\text { Artemia: } 0.081,0.45,0.97,2.06 \text {, } \\
4.03,7.54,15.8,39.3 \text { per ml. } \\
.081,0.52,0.89,3.62,8.96 \\
\text { per ml. }\end{array}$ & $\begin{array}{l}1 \text { jar at each concentration } \\
\text { total }=13 \text { jars }\end{array}$ \\
\hline 非10 & $\begin{array}{l}\text { Isochrysis: } 700 \text { cells/ml. } \\
\text { Nitzschia: } 600 \\
\text { Thalassiosira: } 600 \\
\text { Chroomonas: } 800 \\
\text { Olisthodiscus: } 500 \\
\text { Peridinium: } 250 \\
\text { Cymbomonas: } 500 \\
\text { Erozen Olisthodiscus: } 500\end{array}$ & $\begin{array}{l}\text { same as Experiment }-8 \\
\text { total }=32 \text { jars }\end{array}$ \\
\hline
\end{tabular}



TABLE IV. The Vertical Distribution of

C. plumchrus $\mathrm{V}$ in Saanich Inlet

between 1300-1400 hrs. 19 Dec. 1974

\begin{tabular}{lcccc}
\hline $\begin{array}{l}\text { Sampled Depth } \\
\text { Intervals }\end{array}$ & $\begin{array}{l}\text { Number of } \\
\text { animals counted }\end{array}$ & $\begin{array}{l}\text { Depth } \\
\text { Interval }\end{array}$ & $\begin{array}{l}\text { No. of } \\
\text { Animals } / \mathrm{m}^{3}\end{array}$ & $\begin{array}{l}\text { Percentage } \\
\text { of total }\end{array}$ \\
\hline $0-75 \mathrm{~m}$ & 0 & $0-75 \mathrm{~m}$ & 0 & $0 \%$ \\
$0-100$ & 48 & $75-100$ & 1.22 & $11.1 \%$ \\
$0-125$ & 128 & $100-125$ & 2.04 & $18.5 \%$ \\
$0-150$ & 152 & $125-150$ & 0.61 & $5.5 \%$ \\
$0-175$ & 232 & $150-175$ & 1.83 & $16.6 \%$ \\
$0-200$ & 432 & $175-200$ & 5.30 & $48.1 \%$ \\
\hline
\end{tabular}



TABLE V. Station E. Sumary

Physical Data 17 Oct. 1974

\begin{tabular}{cccccc}
\hline $\begin{array}{c}\text { Depth } \\
(\mathrm{m})\end{array}$ & $\begin{array}{c}\text { Temp } \\
\mathrm{C}\end{array}$ & $\begin{array}{c}\text { Salinity } \\
\text { s }\end{array}$ & Sigma-t & $\begin{array}{c}\mathrm{O}_{2} \\
\mathrm{ml} / \mathrm{l}\end{array}$ & $\begin{array}{c}\text { chlorophyll-a } \\
\mathrm{mg} / \mathrm{m} 3\end{array}$ \\
\hline 0 & 13.20 & 29.42 & 22.07 & 5.50 & 0.25 \\
10 & 11.30 & 29.78 & 22.69 & 3.41 & 1.81 \\
20 & 10.91 & 29.96 & 22.89 & 3.62 & 0.11 \\
30 & 10.67 & 30.19 & 23.17 & 3.70 & - \\
50 & 10.16 & 30.53 & 23.46 & 3.65 & - \\
75 & 9.22 & 31.10 & 24.06 & 1.98 & $0.0 *$ \\
100 & 9.00 & 31.19 & 24.16 & 1.00 & $0.0 *$ \\
150 & 9.02 & 31.31 & 24.25 & 0.90 & $0.0 *$ \\
200 & 9.00 & 31.31 & 24.26 & 0.50 & \\
\hline
\end{tabular}

*undetectable 

TABLE VI. Station E Summary

Physical Data 18 Nov. 1974

\begin{tabular}{cccccc}
\hline $\begin{array}{c}\text { Depth } \\
(\mathrm{m})\end{array}$ & $\begin{array}{c}\text { Temp } \\
\mathrm{C}\end{array}$ & $\begin{array}{c}\text { Salinity } \\
\text { so }\end{array}$ & Sigma-t & $\begin{array}{c}\mathrm{O}_{2} \\
\mathrm{mI} / 1\end{array}$ & $\begin{array}{c}\text { chlorophy 1 - } \mathrm{A} \\
\mathrm{mg} / \mathrm{m} 3\end{array}$ \\
\hline 0 & 8.55 & 26.22 & 20.35 & 5.85 & .085 \\
10 & 8.62 & 27.35 & 21.22 & 4.92 & .089 \\
20 & 8.75 & 28.61 & 22.19 & 4.50 & .025 \\
30 & 9.53 & 29.48 & 22.75 & 3.96 & $0.0 *$ \\
50 & 9.57 & 30.82 & 23.79 & 3.83 & $0.0 *$ \\
75 & 9.46 & 30.92 & 23.88 & 1.88 & $0.0 *$ \\
100 & 9.21 & 30.99 & 23.98 & 0.50 & $0.0 *$ \\
150 & 9.00 & 31.04 & 24.04 & 0.55 & $0.0 *$ \\
200 & 9.00 & 30.96 & 24.77 & 0.35 & $0.0 *$ \\
\hline
\end{tabular}

*undetectable 

TABLE VII. Station E Summary

Physical Data 19 Dec. 1974

\begin{tabular}{cccccc}
\hline $\begin{array}{c}\text { Depth } \\
(\mathrm{m})\end{array}$ & $\begin{array}{c}\text { Temp } \\
\mathrm{C}\end{array}$ & $\begin{array}{c}\text { Salinity } \\
\text { so }\end{array}$ & Sigma-t & $\mathrm{O}_{2}$ & $\begin{array}{c}\text { chlorophyll-a } \\
\mathrm{mg} / \mathrm{m}^{3}\end{array}$ \\
\hline 0 & 8.23 & 27.83 & 21.63 & 5.36 & 0.10 \\
10 & 8.96 & 29.96 & 23.25 & 4.07 & 0.85 \\
20 & 8.94 & 30.08 & 23.24 & 3.83 & $0.0 *$ \\
30 & 8.85 & 30.17 & 23.39 & 3.96 & $0.0 *$ \\
50 & 8.80 & 30.36 & 23.55 & 4.13 & $0.0 *$ \\
75 & 8.65 & 30.52 & 23.69 & 1.35 & $0.0 *$ \\
100 & 8.92 & 30.71 & 23.79 & 1.00 & $0.0 *$ \\
150 & 8.93 & 31.22 & 24.20 & 0.34 & $0.0 *$ \\
\hline 100 & 8.93 & 31.28 & 24.24 & undetectable & $0.0 *$ \\
\hline
\end{tabular}

*undetectable 

TABLE VIII. Station E Summary

Physical Data 16 Jan. 1975

\begin{tabular}{|c|c|c|c|c|c|}
\hline $\begin{array}{l}\text { Depth } \\
\text { (m) }\end{array}$ & $\begin{array}{c}\text { Temp } \\
{ }_{\mathrm{C}}\end{array}$ & $\underset{:}{\text { Salinity }}$ & Sigma-t & $\begin{array}{c}\mathrm{O}_{2} \\
\mathrm{ml} / \mathrm{l}\end{array}$ & $\begin{array}{c}\text { chlorophyll-a } \\
\mathrm{mg} / \mathrm{m}^{3}\end{array}$ \\
\hline 0 & 7.41 & 26.53 & 20.74 & 7.21 & 0.20 \\
\hline 10 & 8.00 & 28.59 & 22.28 & 6.53 & 0.93 \\
\hline 20 & 7.59 & 30.01 & 23.44 & 6.00 & $0.0 *$ \\
\hline 30 & 8.10 & 30.32 & 23.88 & 4.31 & $0.0 *$ \\
\hline 50 & 7.00 & 30.63 & 23.98 & 3.56 & $0.0 *$ \\
\hline 75 & 7.05 & 31.06 & 24.34 & 2.21 & $0.0 *$ \\
\hline 100 & 6.98 & 31.11 & 24.38 & 0.25 & $0.0 *$ \\
\hline 150 & 7.00 & 31.12 & 24.39 & 0.10 & $0.0 *$ \\
\hline 200 & 7.00 & 31.12 & 24.39 & $\begin{array}{l}\text { undetect- } \\
\text { able }\end{array}$ & $0.0 *$ \\
\hline
\end{tabular}

*undetectable 

TABLE IX. Strait of Georgia Summary

Physical Data 1 November 1974

\begin{tabular}{|c|c|c|c|c|c|}
\hline $\begin{array}{l}\text { Depth } \\
\text { (m) }\end{array}$ & $\begin{array}{l}\text { Temp } \\
{ }^{\circ} \mathrm{C}\end{array}$ & Salinity & Sigma-t & $\begin{array}{c}\mathrm{O}_{2} \\
\mathrm{mI} / \mathrm{I}\end{array}$ & $\begin{array}{c}\text { chlorophyll-a } \\
\mathrm{mg} / \mathrm{m}^{3}\end{array}$ \\
\hline 400 & 8.92 & 31.25 & 24.22 & 3.04 & 0.00 \\
\hline
\end{tabular}



TABLE X. Experiment 9-B. The Ingestion of Artemia sp. rauplii by Calanus pacificus

\begin{tabular}{|c|c|c|c|c|}
\hline $\begin{array}{l}\text { Initial } \\
\text { Artemia } \\
\text { Concentration }\end{array}$ & $\begin{array}{l}\text { Volume } \\
\text { of } \\
\text { Aliquots }\end{array}$ & $\begin{array}{l}\text { Number of Artemia } \\
\text { time } 0\end{array}$ & $\begin{array}{l}\text { in aliquot } \\
\text { time } 0+ \\
24 \text { hrs. }\end{array}$ & $\begin{array}{l}\text { *Ingestion } \\
\text { Rate } \\
\text { (Artemia cope- } \\
\text { pod }^{-1} \text { hr. }{ }^{-1} \text { ) }\end{array}$ \\
\hline .081 per $\mathrm{ml}$. & -- & 65 & 25 & 0.11 \\
\hline 0.52 & $75 \mathrm{ml}$ & 39 & 8 & 0.92 \\
\hline 0.89 & 75 & 67 & 29 & 1.13 \\
\hline 3.62 & 50 & 181 & 128 & 2.36 \\
\hline 8.96 & 25 & 224 & 141 & 7.37 \\
\hline
\end{tabular}

$* I . R .=\frac{\text { (Initial concentration) }- \text { (final concentration) } \times 800 \mathrm{mls}}{\text { (volume of aliquot) }(15 \text { copepods })(24 \text { hrs.) }}$ 



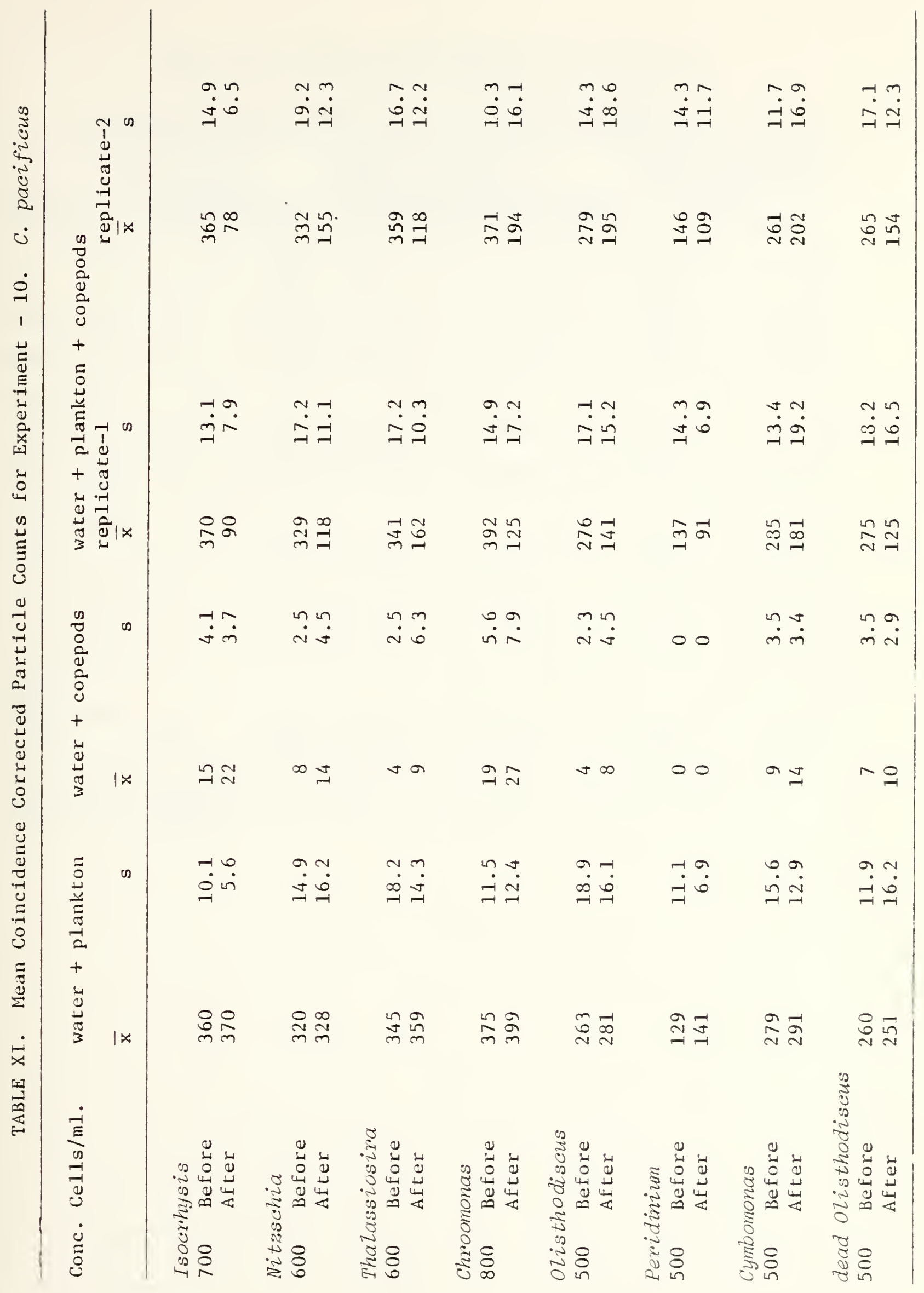



TABLE XII. The Ingestion Rates of $C$. pacificus

Feeding on Different Phytoplankton Cultures in Experiment - 10

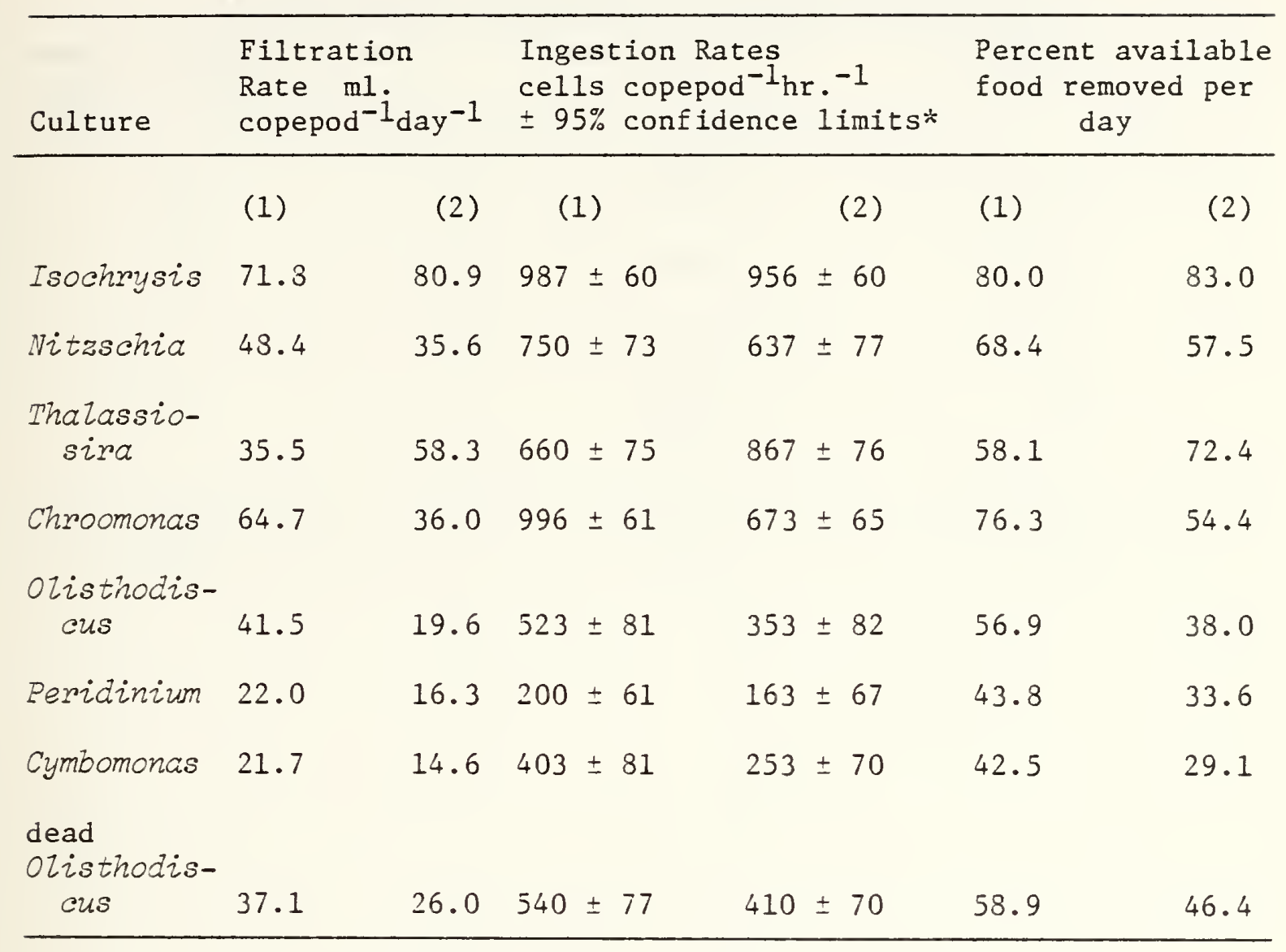

*Method for calculating confidence limits is described in the Appendix: page 85 . 

TABLE XIII. Summary of Calibration Factors (F)

Determined from Ammonia Standardization Runs

\begin{tabular}{ccc}
\hline $\begin{array}{c}\text { Ammonia } \\
\text { ugm-At }\end{array} \mathrm{NH}_{3} / 2$ & $\begin{array}{c}\text { Experiment } \\
\mathrm{F}\end{array}$ & $\begin{array}{c}\text { Experiment } 12 \\
\mathrm{~F}\end{array}$ \\
\hline 0.1 & 3.22 & 2.70 \\
0.2 & 4.34 & 4.17 \\
0.4 & 4.21 & 6.45 \\
1.0 & 4.95 & 5.59 \\
2.0 & 5.31 & 2.65 \\
\hline mean & 4.41 & 4.31 \\
\hline
\end{tabular}



TABLE XIV. A Summary of the Ammonia Excretion

Rates of Calanus plumchms V from Experiment - 11

\begin{tabular}{|c|c|c|c|c|c|}
\hline $\begin{array}{l}\text { No. of } \\
\text { Animals } \\
\text { per jar }\end{array}$ & $\begin{array}{l}\text { Mean } \\
\text { copepod } \\
\text { weight } \\
\text { (mg.) }\end{array}$ & $\begin{array}{l}\text { Hgm-At } N \\
\text { mg dry weight } \\
\text { day }{ }^{-1} \\
\left(\mathrm{X}^{-1} 0^{-3}\right)\end{array}$ & $\begin{array}{l}\text { Hgin-At N } \\
\text { anima } 1^{-1} \\
\text { day-1 } \\
\left(\mathrm{X} 10^{-3}\right)\end{array}$ & $\begin{array}{l}\text { Days to } \\
\text { exhaustion } \\
\text { of total } \\
\text { body } \\
\text { nitrogen }\end{array}$ & $\begin{array}{l}\% \text { of total } \\
\text { body } \\
\text { nitrogen } \\
\text { excreted } \\
\text { per day }\end{array}$ \\
\hline 5 & .900 & 18.26 & 16.43 & 274 & 0.36 \\
\hline 6 & .752 & 6.67 & 5.05 & 749 & 0.13 \\
\hline 8 & .988 & 11.37 & 11.23 & 440 & 0.23 \\
\hline 10 & .870 & 22.00 & 19.14 & 227 & 0.44 \\
\hline 20 & .915 & 16.55 & 15.14 & 303 & 0.33 \\
\hline 20 & .793 & 9.77 & 7.75 & 514 & 0.19 \\
\hline 27 & .782 & 17.11 & 13.38 & 292 & 0.34 \\
\hline 30 & .784 & 17.65 & 13.83 & 282 & 0.35 \\
\hline 39 & .812 & 17.45 & 14.17 & 287 & 0.35 \\
\hline 35 & .845 & 9.43 & 7.96 & 532 & 0.19 \\
\hline 50 & .797 & 13.36 & 14.63 & 271 & 0.37 \\
\hline 56 & .349 & 24.72 & 20.98 & 202 & 0.49 \\
\hline 107 & .740 & 14.15 & 10.47 & 352 & 0.28 \\
\hline 113 & .814 & 12.26 & 9.97 & 406 & 0.25 \\
\hline mean & .780 & 15.41 & 12.87 & 366 & 0.30 \\
\hline $\begin{array}{l}95 \% \text { con- } \\
\text { fidence } \\
\text { limits }\end{array}$ & .104 & 2.92 & 2.57 & 86.2 & 0.06 \\
\hline
\end{tabular}



TABLE XV. A Summary of the Ammonia Excretion

Rates of Calanus plumchrus V from Experiment - 12

\begin{tabular}{|c|c|c|c|c|c|}
\hline $\begin{array}{l}\text { No. of } \\
\text { Animals } \\
\text { per jar }\end{array}$ & $\begin{array}{l}\text { Mean } \\
\text { copepod } \\
\text { weight } \\
\text { (mg.) }\end{array}$ & $\begin{array}{l}\text { ugm-At } N \\
\text { mg dry weight } \\
\text { day }{ }^{-1} \\
\left(\mathrm{X}^{-1} 0^{-3}\right)\end{array}$ & $\begin{array}{l}\mu \text { gm-At } N \\
\text { animal-1 } \\
\text { day }^{-1} \\
\left(\mathrm{XIO}^{-3}\right)\end{array}$ & $\begin{array}{l}\text { Days to } \\
\text { exhaustion } \\
\text { of total } \\
\text { body } \\
\text { nitrogen }\end{array}$ & $\begin{array}{l}\% \text { of total } \\
\text { body } \mathrm{N} \\
\text { excreted } \\
\text { per day }\end{array}$ \\
\hline 20 & .715 & 15.21 & 10.86 & 329 & 0.30 \\
\hline 20 & .759 & 19.00 & 14.42 & 264 & 0.38 \\
\hline 18 & .908 & 14.00 & 12.71 & 357 & 0.28 \\
\hline 19 & .300 & 15.20 & 12.16 & 329 & 0.30 \\
\hline 21 & .781 & 17.76 & 13.87 & 281 & 0.36 \\
\hline 20 & .881 & 15.19 & 13.38 & 329 & 0.30 \\
\hline 20 & .827 & 13.39 & 11.07 & 373 & 0.27 \\
\hline 18 & .938 & 12.58 & 11.80 & 398 & 0.25 \\
\hline 19 & .826 & 14.08 & 11.63 & 354 & 0.28 \\
\hline 20 & .925 & 14.31 & 13.24 & 350 & 0.28 \\
\hline 21 & .834 & 16.24 & 13.54 & 308 & 0.32 \\
\hline 20 & .838 & 16.78 & 14.06 & 297 & 0.33 \\
\hline 20 & .933 & 13.82 & 12.89 & 362 & 0.27 \\
\hline 21 & .852 & 14.30 & 12.18 & 348 & 0.28 \\
\hline 20 & .939 & 13.22 & 12.41 & 377 & 0.26 \\
\hline 20 & .832 & 17.40 & 14.47 & 286 & 0.35 \\
\hline 20 & .873 & 15.74 & 13.74 & 318 & 0.31 \\
\hline 20 & .792 & 17.83 & 14.12 & 279 & 0.36 \\
\hline 21 & .806 & 16.81 & 13.54 & 298 & 0.33 \\
\hline 20 & .915 & 13.72 & 12.55 & 363 & 0.27 \\
\hline$\overline{\bar{x}}$ & .849 & 15.33 & 12.93 & 330 & 0.34 \\
\hline $\begin{array}{l}95 \% \text { con- } \\
\text { fidence } \\
\text { limits }\end{array}$ & 0.030 & 0.841 & 0.506 & 17.6 & 0.04 \\
\hline
\end{tabular}



TABLE XVI. Summary of

CaZanus sp. Nitrogen Excretion Rates

\begin{tabular}{|c|c|c|c|c|}
\hline Reference & Species & $\begin{array}{l}\text { Hgm At }-\mathrm{N} \\
\text { mg dry wt. }-1 \\
\text { copepod day }\end{array}$ & $\begin{array}{l}\% \text { of total } \\
\text { body } N \\
\text { excreted } \\
\text { per day }\end{array}$ & $\begin{array}{l}\text { days to } \\
\text { exhaustion } \\
\text { of total } \\
\text { body } N\end{array}$ \\
\hline
\end{tabular}

$\begin{array}{llccr}\text { Exp't } 11 & \text { C. plumchrus V } & 0.0154 & 0.30 & 366 \\ \text { Exp't } 12 & \text { C. plumchrus V } & 0.0153 & 0.34 & 330\end{array}$

Taguchi and

Ishi (1972)

C. plumcinrus $V$

0.227

3.44

29

Corner and

Newell

(1967)

C. helgolandicus

(adult) $\quad 0.238$

4.75

21

Butler et

al. (1969)

C. finmarchicus $V \quad 0.172$

15.5

6.5

C. he Zgolandicus $V 0.076$

6.8

15

Conover and

Corner

(1965)

C. hyperboreus $V \quad 0.059$

1.34

75

Corner et

al. (1965)

C. finmarchicus $V$

0.55

7.71

13

Butler et

aZ. (1970)

C. he Zgolandicus V $0.114-0.700$

$2 \cdot 3-14 \cdot 0$

$7-44$

Littlepage and

Rose (1973) C. piumchrus $V \quad 0.46-0.90 \quad 9.2-18 \quad 5.5-10.9$



Key to Tables A-I - A-VIII

1: Concentration (cells/ml) column: refers to the approximate cell concentration in each jar.

2: $\bar{x}$ : mean particle counts: the mean of 5 separate counts by the Coulter Counter Volume sampled in each count - $0.5 \mathrm{mls}$ except for Experiment 7 where Volume $=2.0 \mathrm{mls}$.

3: $\quad S=$ standard deviation of variation

$=\frac{\bar{x}}{\bar{s}} \times 100 \%$

4: $B=$ particle concentration BEFORE start of experiment $A=$ particle concentration AFTER duration of experiment 



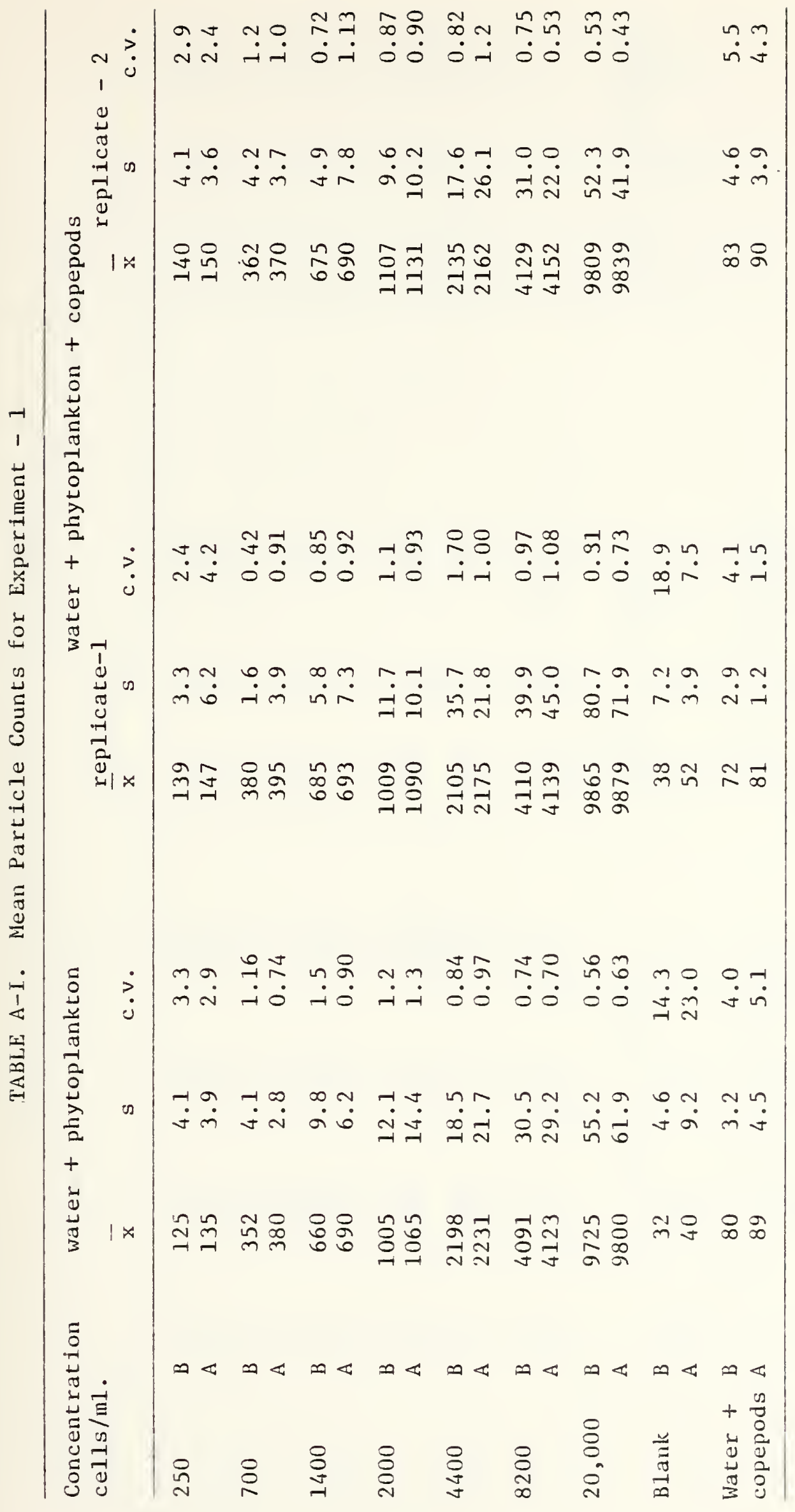





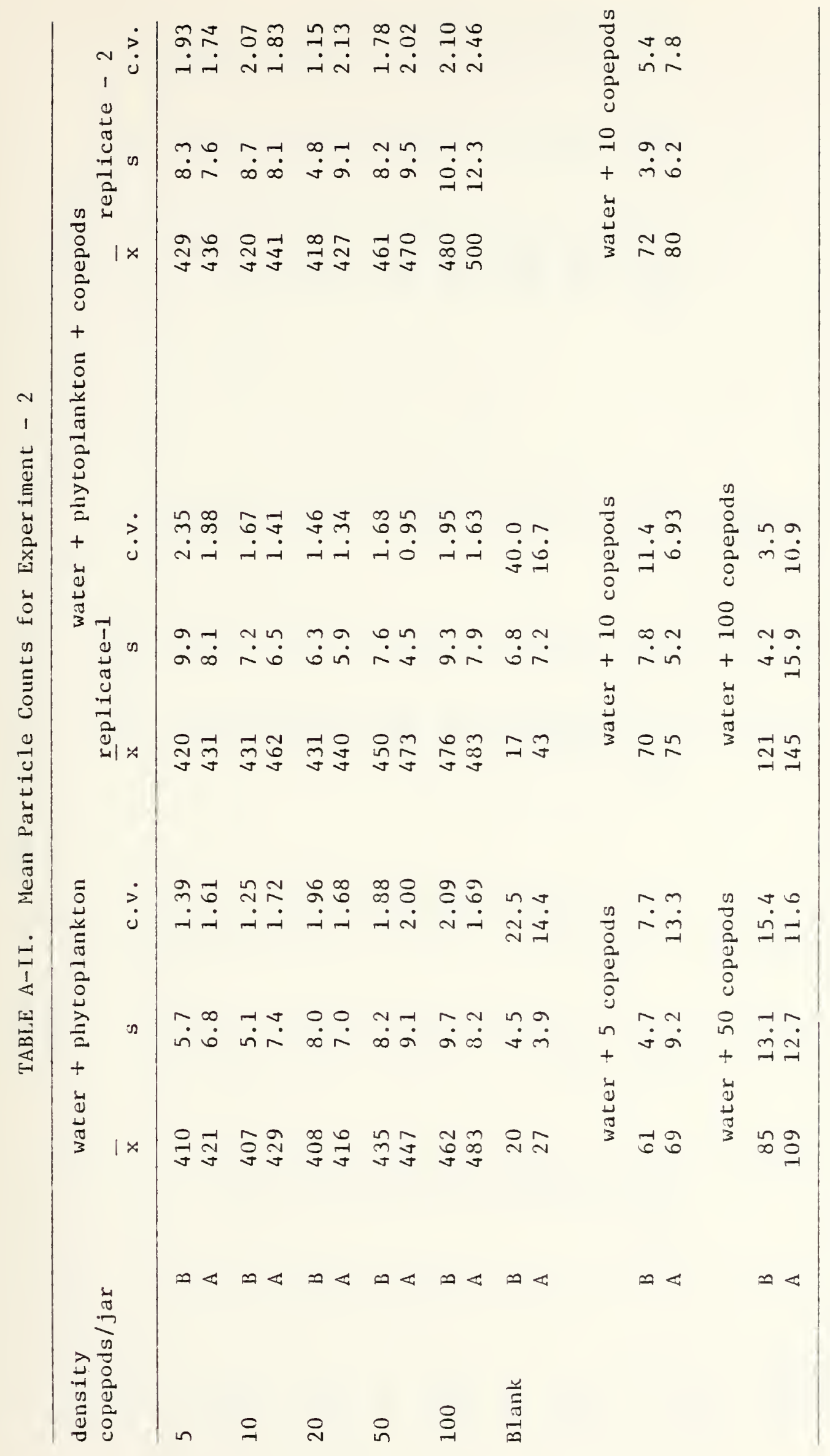





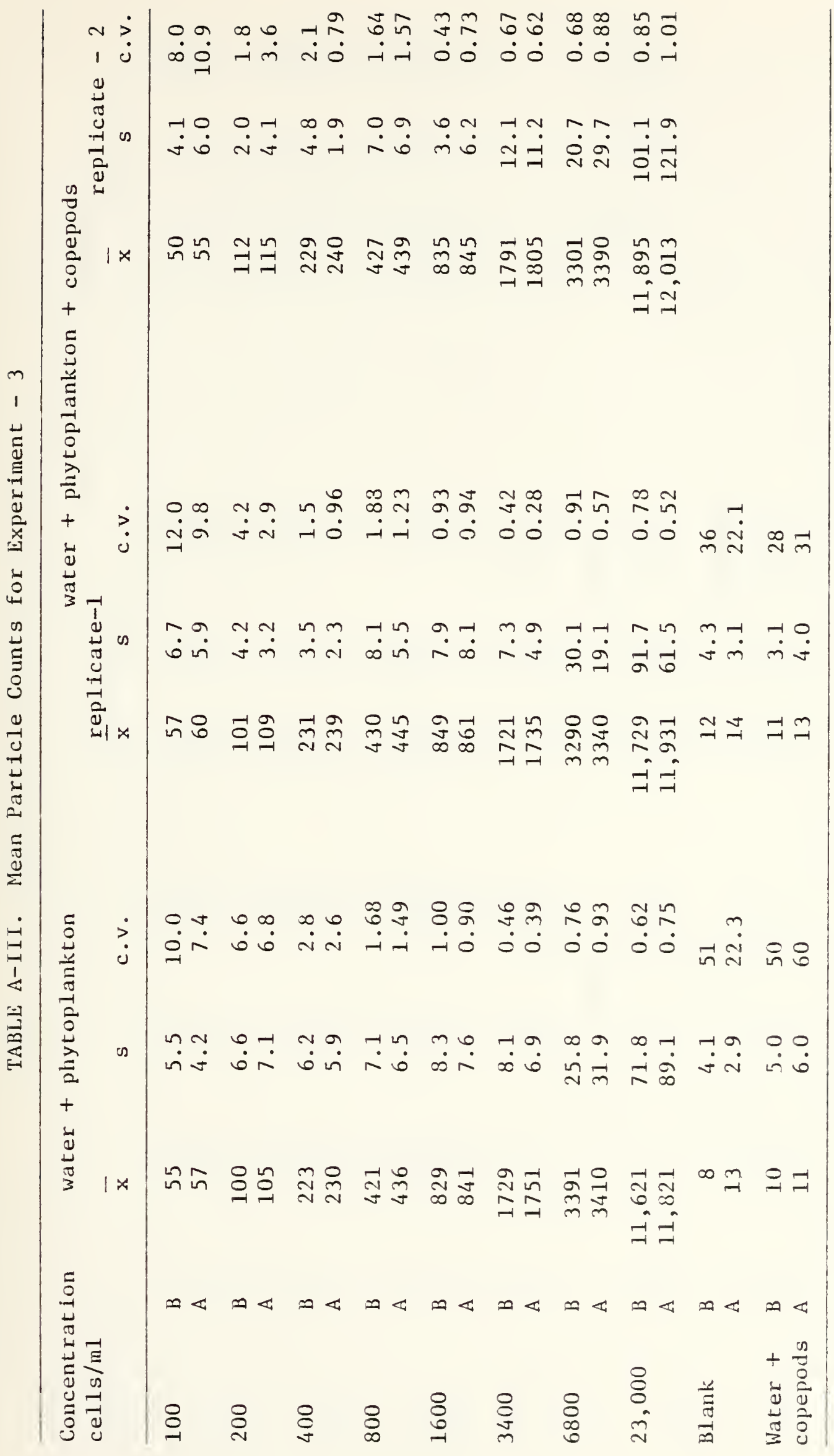





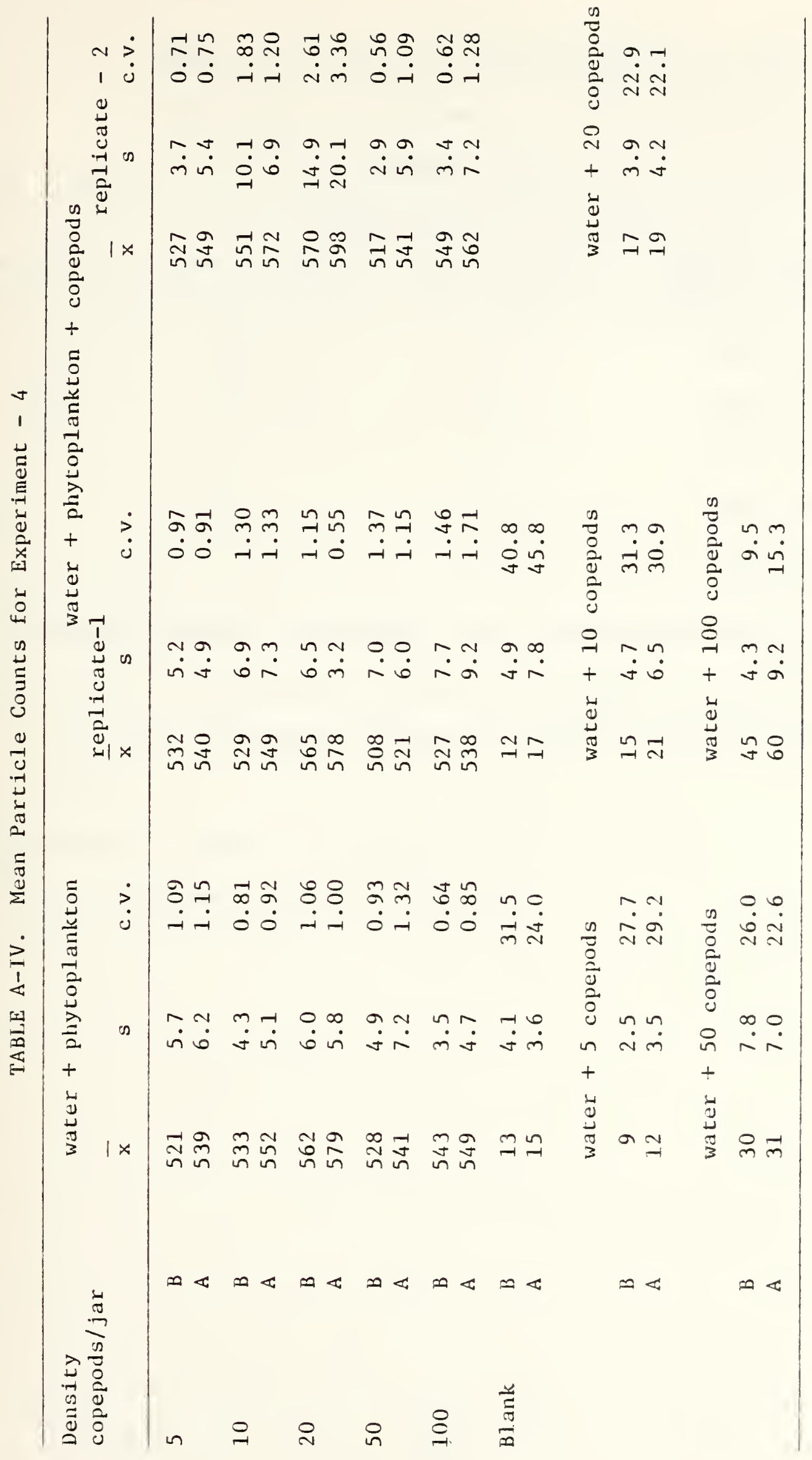



TABLE A-V. Chlorophyll-a Concentrations of the

Feeding Jars in Experiment - 4 at the end of the

Feeding Period

\begin{tabular}{|c|c|c|c|}
\hline \multirow[b]{2}{*}{ water only } & \multicolumn{3}{|c|}{ Chlorophyll concentrations in $\mathrm{mg} / \mathrm{m}^{3}$} \\
\hline & water + copepods & $\begin{array}{l}\text { water + plankton } \\
(5 \text { jars })\end{array}$ & $\begin{array}{l}\text { water }+ \text { plankton }+ \\
\text { copepods ( } 10 \text { jars) }\end{array}$ \\
\hline 0.00 & 0.00 & 1.99 & $1.92,1.76$ \\
\hline \multirow[t]{4}{*}{0.00} & 0.00 & 2.23 & $2.02,2.31$ \\
\hline & & 2.00 & $2.23,2.18$ \\
\hline & & 2.36 & $1.39,1.36$ \\
\hline & & 1.95 & $2.19,2.24$ \\
\hline
\end{tabular}

Statistical analysis: Independent t test (Sokal and Rohlf 1969)

Ho: there is no difference between the chlorophyll-a concentrations of the "water + plankton" jars and the "water + plankton + copepods" jars.

Calculated $t=+0.657 \quad t_{.05(13)}=2.16$

The null hypothesis is therefore accepted. 



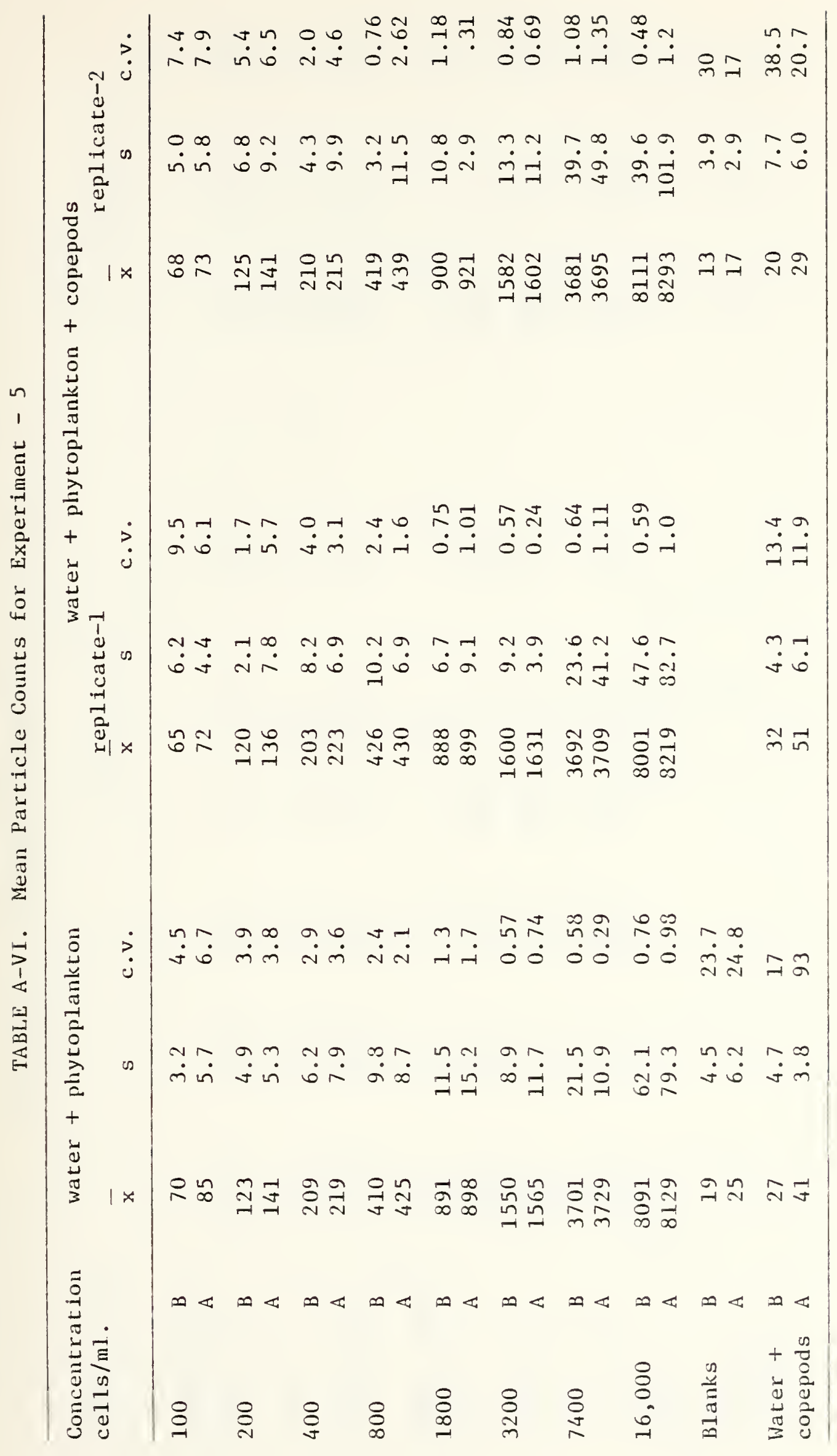





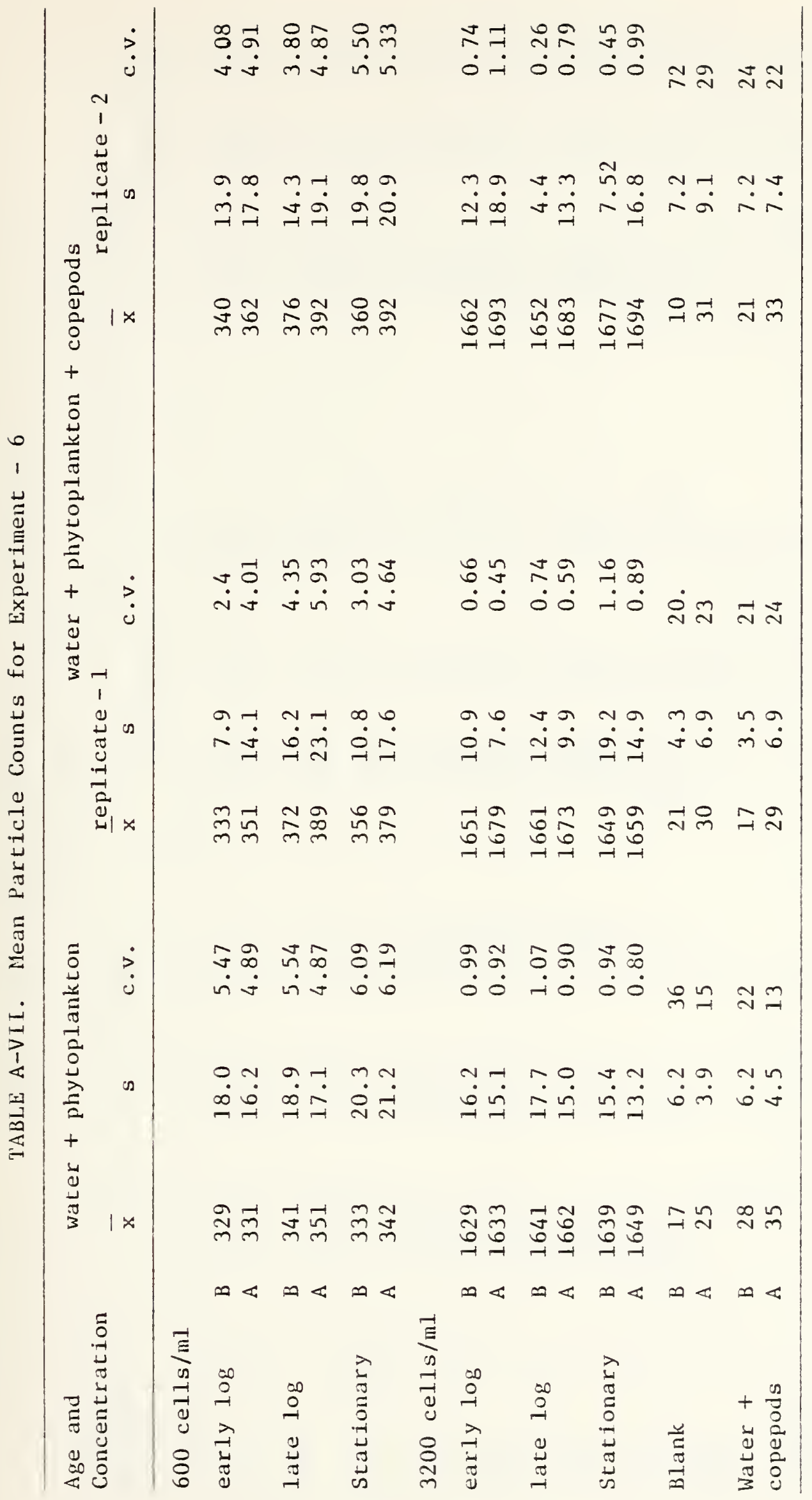





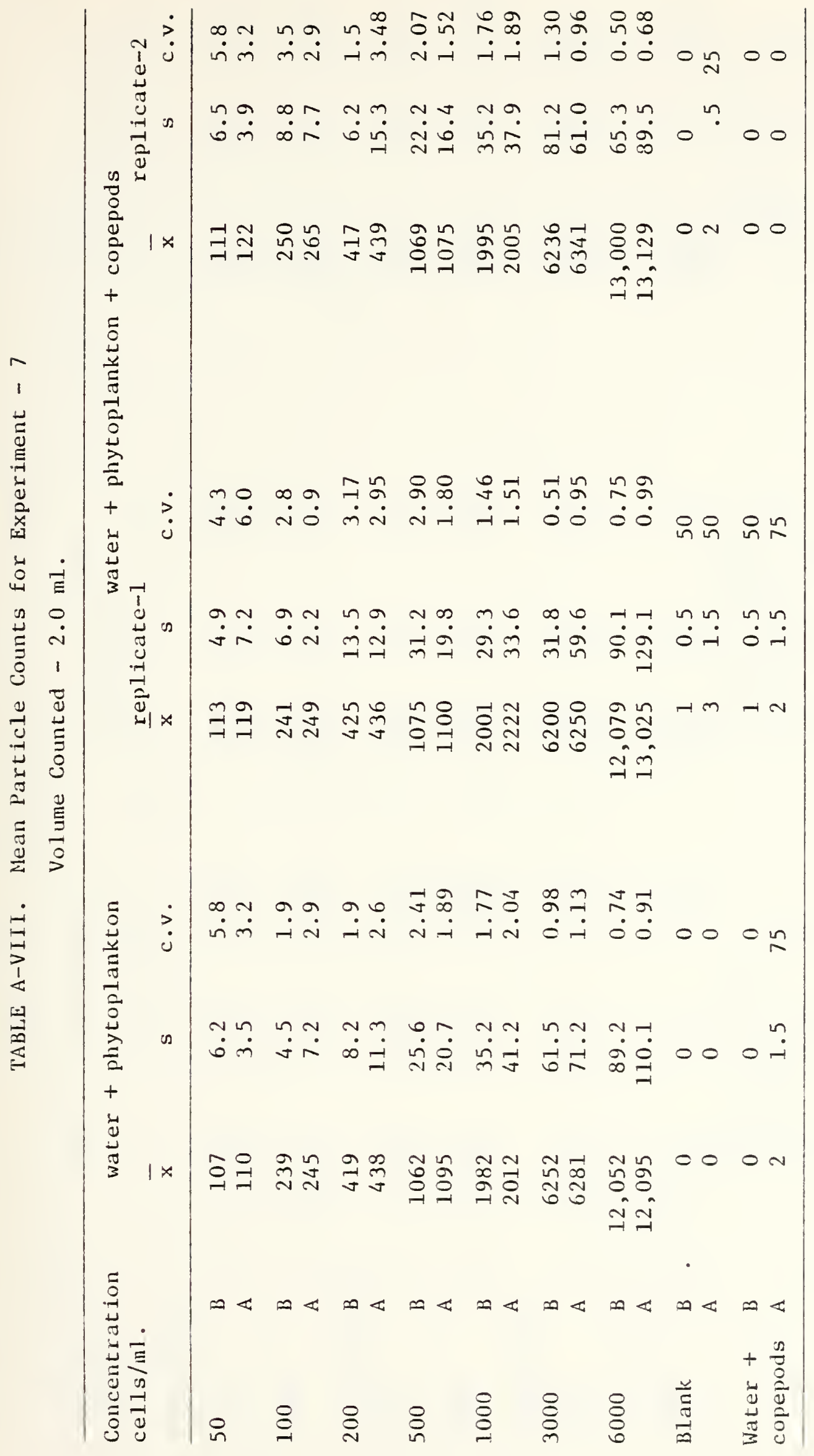





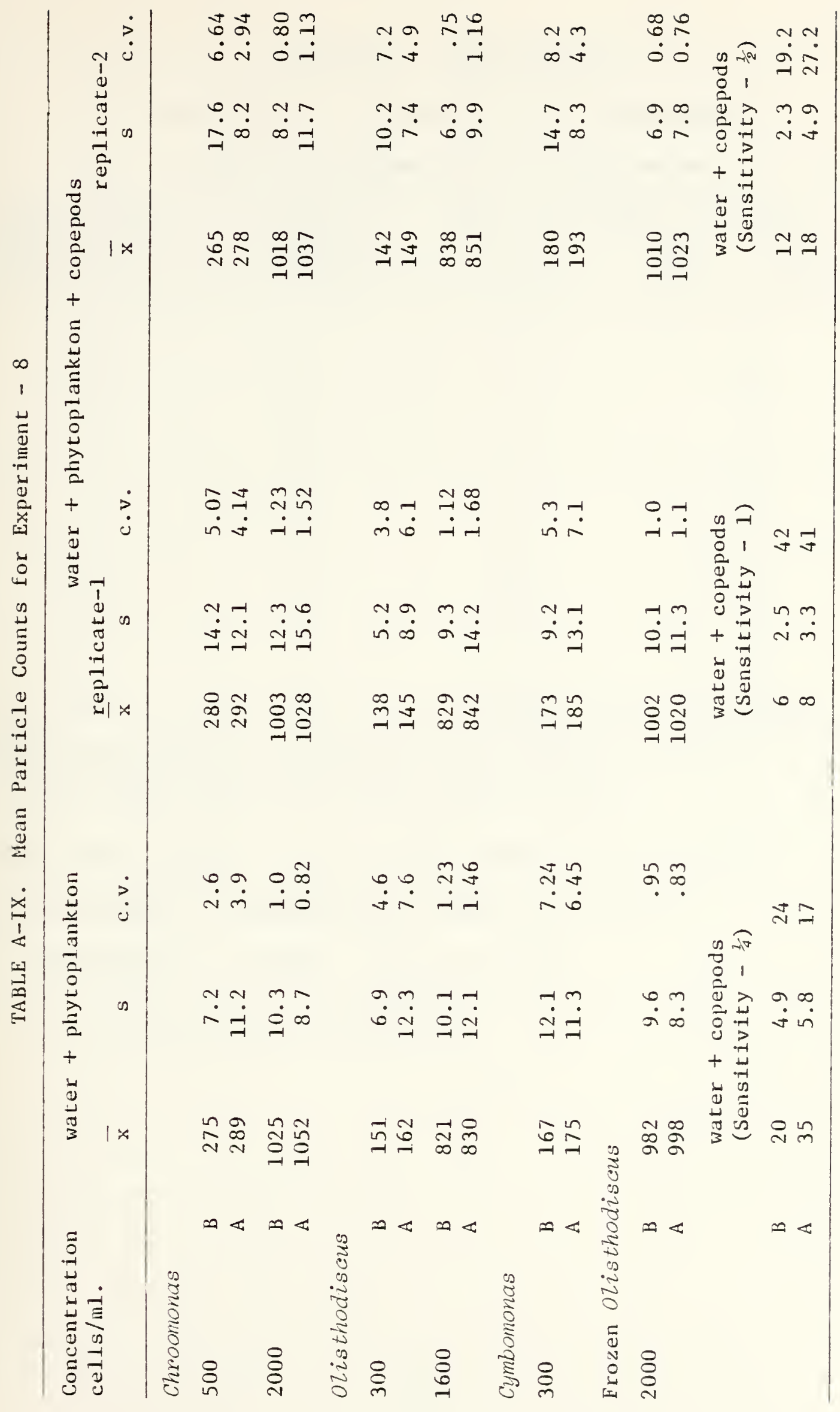



TABLE A-X. Experiment 9-A.

The effect of C. plumchrus on the concentration of Artemia larvae over a 24 hour period

\begin{tabular}{cccc}
\hline $\begin{array}{l}\text { Initial Artemia } \\
\begin{array}{l}\text { Concentration } \\
\text { (animals per ml. })\end{array}\end{array}$ & $\begin{array}{c}\text { Volume of } \\
\text { Aliquot } \\
\text { (in mls. })\end{array}$ & time 0 & time $0+24$ hrs. \\
\hline 0.081 & $*--$ & 65 & 71 \\
0.45 & 75 & 34 & 36 \\
0.97 & 75 & 73 & 70 \\
2.06 & 75 & 155 & 148 \\
4.03 & 50 & 202 & 221 \\
7.54 & 25 & 189 & 180 \\
15.8 & 12 & 190 & 201 \\
39.3 & 5 & 196 & 190 \\
\hline
\end{tabular}

*concentration was not determined by the removal of aliquots. Instead, a known number (65) animals were added to the jar.

Statistical analysis: Paired t-test (Sokal and Rohlf, 1969).

Ho: the number of Artemia did not change over 24 hrs.

calculated $t=-0.468 \quad t_{.05(7)}=2.368$.

The null hypothesis is accepted. 

Method of calculating $95 \%$ confidence limits for Ingestion rates in Table XII (Gregory, 1981; pers. comm.).

$$
\bar{x} \pm t(.05)(n-1) s_{x_{1}}-\bar{x}_{2}+\bar{x}_{3}-\bar{x}_{4}+\bar{x}_{5}-\bar{x}_{6}
$$

where: $\bar{x}=$ mean change in the number of cells per $0.5 \mathrm{ml}$ and:

$$
\begin{aligned}
& S_{\bar{x}_{1}}-\bar{x}_{2}+\bar{x}_{3}-\bar{x}_{4}+\bar{x}_{5}-\bar{x}_{6} \text { (the standard error) } \\
& =\frac{2 \mathrm{Sp}}{n}
\end{aligned}
$$

where: $n=$ number of counts made on Coulter Counter to determine each mean concentration.

$\mathrm{Sp}$ is a pooled estimate of the variance

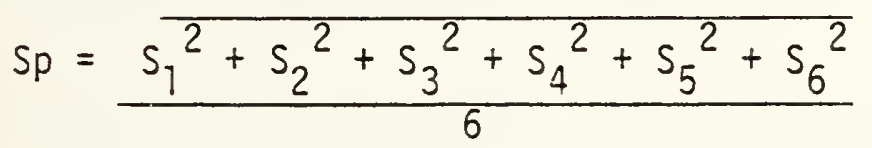

where: $s_{7}{ }^{2} \ldots s_{6}{ }^{2}$ are the variances of the mean concentration before and after the $24 \mathrm{hr}$. feeding period in the 2 control jars and the experimental jar, with each variance based on 5 separate counts with the Coulter Counter.

Confidence limits for Ingestion Rate

$$
=\frac{(\text { above calculated } 7 \mathrm{imits})(800 \mathrm{mls} / \mathrm{jar})}{(24 \mathrm{hrs} .)(20 \text { copepods } / \mathrm{jar})} \times 2
$$



Adams, J. A. and Steele, H. H. 1966. Shipboard experiments on the feeding of Calanus finmarchicus (Gunnerus). In "Some Contemporary Studies in Marine Science" ( $H$. Barnes, ed.) pp. 19-35. Allen and Unwin, London.

Anraku, M. and Omori, M. 1963. Preliminary survey of the relationship between the feeding habit and the structure of the mouth parts of marine copepods. Limnol. Oceanogr. 8:116-126.

Barraclough, W. E., Lebrasseur, R. J. and Kennedy, R. D. 1969. Shallow scattering layer in the sub-Arctic Pacific Ocean. Detection by high frequency echo sounder. Science 166:611-613.

Bary, B. 1966. Qualitative observations of scattering of $12 \mathrm{kc} / \mathrm{s}$ sound in Saanich Inlet, British Columbia. Deep Sea Res. 13:667-677.

Bary, B. 1966. Back scattering at $12 \mathrm{Kc} / \mathrm{s}$ in relation to biomass and numbers of zooplanktonic organisms in Saanich Inlet, British Columbia. Deep Sea Res. 13:655-666.

Bary, B. and Pieper, R. E. 1971. Sonic scattering studies in Saanich Inlet, British Columbia: A preliminary report. P. 601-611 in: Farquhar, G. B. (ed.). Proceedings of an international symposium on biological sound scattering in the ocean. Maury Center for Ocean Science, Washington, D.C.

Baylor, E. R. and Sutcliffe, W. H. 1963. Dissolved organic matter in seawater as a source of particulate food. Limnol. Oceanogr. 8:369-371.

Baylor, E. R., Sutcliffe, W. H. and Hirschfeld, D. S. 1962. Adsorption of phosphates onto bubbles. Deep Sea Res. 9:120-124.

Beyer, F. 1962. Absorption of water in crustaceans, and the standing crop of zooplankton. Rapp. Cons. Explor. Mer. 153:79-85.

Brodskii, K. A. 1950. Calanoida of the Far Eastern Seas and Polar Basins of the USSR, translated from Russian by A. Mercada. Jerusalem: Israel Programme for Scientific Translations. $440 \mathrm{pp}$.

Butler, E. I., Corner, E. D. S. and Marsha11, S. M. 1969. On the nutrition and metabolism of zooplankton. VI. Feeding efficiency of Calanus in terms of nitrogen and phosphorous. J. Mar. Biol. Ass. U.K., 49:977-1003. 

Butler, E. I., Corner, E. D. S. and Marshal1, S. M. 1970. On the nutrition and metabolism of zooplankton. VII. Seasonal survey of nitrogen and phosphorous excretion by Calanus in the Clyde Sea area. J. Mar. Biol. Ass. U.K. 50:525-560.

Campbe11, M. H. 1934. The life history and post embryonic development of the copepods Calanus tonus Brady and Euchaeta japonica Marukawa. J. Biol. Bd. Can. 1:1-65.

Castille, R. D. 1975. Reverberation from Plankton at $330 \mathrm{KHZ}$ in the western Pacific. J. Acoust. Soc. Amer. 58:972-976.

Chapman, P. M. 1975. Uptake and assimilation of dissolved glucose from seawater by Calanus plumchrus Marukawa. M.Sc. thesis, University of Victoria.

Childress, J. J. 1968. Oxygen minimum layer: vertical distribution and respiration of the mysid Gnathophausia ingens. Science 160:12421243.

Childress, J. J. 1975. The respiratory rates of midwater crustaceans as a function of depth of occurrence and relation to the oxygen minimum layer off Southern California. Comp. Biochem. Physiol. 50A:789-799.

Conover, R. J. 1962. Metabolism and growth in Calanus hyperboreus in relation to its life cycle. Rapp. Cons. ExpTor. Mer. 153:190-197.

Conover, R. J. 1964. Food relations and nutrition of zooplankton. Symp. Exp. Mar. Ecol., In Narragansett Mar. Lab. Occ. Pub7. No. 2:81-89. Cited by Corner, E. D. S. and Conwey, C. B. 1968. Biol Rev. 43: 393-426.

Conover, R. J. 1966. Feeding on large particles by $\mathrm{Ca}$ lanus hyperboreus (Krbyer). In "Some Contemporary Studies in Marine Science" (H. Barnes, Ed.) pp. 19-35. Alien and Unwin, London.

Conover, R. J., and Corner, E. D. S. 1968. Respiration and nitrogen excretion by some marine zooplankton in relation to their life cycles. J. Mar. Biol. Ass. U.K. 48:49-75.

Corner, E. D. S. and Cowey, C. B. 1964. Some nitrogenous constituents of the plankton. Oceanogr. Mar. Biol. Ann. Rev. 2:147-167.

Corner, E. D. S. and Cowey, C. B. 1968. Biochemical studies on the production of marine zooplankton. Biol. Rev. 43:393-426.

Corner, E. D. S., Cowey, C. B. and Marshal1, S. M. 1965. On the nutrition and metabolism of zooplankton. III. Nitrogen excretion by Calanus. J. Mar. Biol. Ass. U.K. 45:429-442. 

Corner, E. D. S., Cowey, C. B. and Marshal1, S. M. 1967. On the nutrition and metabolism of zooplankton. $V$. Feeding efficiency of Calanus finmarchicus. J. Mar. Biol. Ass. U.K. 47:259-270.

Corner, E. D. S. and Davies, A. G. 1971. Plankton in nitrogen and phosphorous cycles. In "Advances in Marine Biology". (Russe11, F. S. and Yonge, M. ed.). Vol. 9:102-204.

Corner, E. D. S., Head, R. N. and Kilvington, C. C. 1972. On the nutrition and metabolism of zooplankton. VIII. The grazing of Biddulphia cells by Calanus helgolandicus. J. Mar. Biol. Ass. U.K. 52:847-861.

Corner, E. D. S., Head, R. N., Kilvington, C. C. and Marsha11, S. M. 1974. On the nutrition and metabolism of zooplankton. IX. Studies relating to the nutrition of overwintering Calanus. J. Mar. Biol. Ass. U.K. 54:319-331.

Corner, E. O. S., Head, R. N., Kilvington, C. C. and Pennycuick, L. 1976. On the nutrition and metabolism of zooplankton. $X$. Quantitative aspects of Calanus helgolandicus feeding as a carnivore. J. Mar. Biol. Ass. U.K. 56: $\overline{345-358 .}$

Corner, E. D. S. and Newe11, B. S. 1967. On the nutrition and metabolism of zooplankton. IV. The forms of nitrogen excreted by Calanus. J. Mar. Biol. Ass. U.K. 47:113-120.

Cowey, C. B. and Corner, E. D. S. 1962. The amino acid composition of Calanus helgolandicus (Claus) in relation to that of its food. Rapp. Cons. ExpTor. Mer. 153:124-128.

Cowey, C. B. and Corner, E. D. S. 1963a. Amino acids and some other nitrogenous compounds in Calanus finmarchicus. J. Mar. Biot. Ass. U.K. 43:485-493.

Cowey, C. B. and Corner, E. D. S. 1963b. On the nutrition and metabolism of zooplankton. II. The relationship between the marine copepod Calanus helgolandicus and particulate matter in Plymouth seawater, in terms of amino acid composition. J. Mar. Biol. Ass. U.K. 43:495-511.

Devol, A. H. 1981. Vertical distribution of zooplankton respiration in relation to the intense oxygen minimum zones in two British Columbia fjords. J. Plankton Res. 3:593-602.

Dietrich, G., Kalle, K., Krauss, W. and Siedler, G. 1975. Oceanography 2nd ed., Wiley and Sons.

Digby, P. S. B. 1954. The biology of the marine planktonic copepods of Scoresby Sound, East Greenland. J. Animal Ecol. 23:298:338. 

Drinnan, R. W. and Littlepage, J. L. 1971. Handbook for Oceanographic Observations. University of Victoria, $117 \mathrm{pp}$.

Elgmork, K. and Nilssen, J.P. 1978. Equivalence of copepod and insect diapause. Verh. int. Verein theor. angew. Limno1. 20:2511-2517.

Esaias, W. E. and Curl, H. C. 1972. Effect of Dinoflagellate bioluminescence on copepod ingestion rates. Limnol. oceanogr. 17:901906.

Farquhar, G. B. 1977. Biological Sound Scattering in the Sea. P. 493 In: Oceaninic Sound Scattering Prediction. Edited by Anderson, N. R. Plenum Press.

Fulton, J. 1973a. Some aspects of the life history of Calanus plumchrus in the Strait of Georgia. J. Fish. Res. Bd. Can. 30:811-815.

Fulton, J. 1973b. Keys and References to the Marine Copepoda of B.C. Fish. Res. Bd. Can. Technical Report No. 313.

Gardner, G. A. 1972. The distribution of the life history stages of Calanus plumchrus. Marukawa (Copepoda: Calanoidea) in the St. of Georgia. M.Sc. Thesis, Univ. of British Columbia.

Gauld, D. T. 1951. The grazing rate of planktonic copepods. J. Mar. Biol. Ass. U.K. 29:695-706.

Gatten, R. R., Corner, E. D. S., Kilvington, C. C. and Sargent, J. R. 1978. A seasonal survey of the lipids in Calanus helgolandicus Claus from the English Channel. In: Cyclic Phenomena in Marine Plants and Animals: Proceedings of the 13th European Marine Biological Symposium, Isle of Man, Pergammon.

Gatten, R. R., et al., 1980. On the nutrition and metabolism of zooplankton. XIV. Utilization of lipid by Calanus helgolandicus during maturation and reproduction. J. Biol. Ass. U.K. 60:391-399.

Gregory, P. T. 1981. Personal communication.

Guillard, R. R. L. and Ryther, J.H. 1962. Studies of Marine phytoplankton diatoms. I. Cyclotella nana (Husteat) and Detonula conferracea (Cleve). Can. J. Microbiol. 8:229-239.

Hallberg, E. and Hirche, H. J. 1980. Differentiation of mid-gut in adults and over-wintering copepodites of Calanus finmarchicus (Gunnerus) and $\underline{C}$. helgolandicus Claus. J. exp. mar. Biol. Ecol. 18:283-295. 

Hansen, W. J. and Dunbar, M. J. 1970. Biological causes of sound scattering in the Arctic Ocean, p. 508-526 in: Farquhar, G. B. (ed.). Proceedings of an international symposium on biological sound scattering in the ocean. Maury Center for Ocean Science, Washington, D.C.

Harding, G. C. H. 1974. The food of Deep-Sea Copepods. J. Mar. Biol. Ass. U.K. 54:141-155.

Harris, E. 1959. The nitrogen cycle in Long Island Sound. Bul1. Bingham Oceanogr. Col1. 17:31-65. Cited by Conover, R. J. and Corner, E. D. S. 1968. J. Mar. Biol. Ass. U.K. 48:49-75.

Heinle, R., et al. 1977. Detritus as food for estuarine copepods. Marine Biology $40: 341-353$.

Heinrich, A. K. 1962. The life histories of plankton animals and seasonal cycles of plankton communities in the oceans. J. Cons. Int. Explor. Mer. 27(1):15-24.

Hirche, H. J. 1978. On the occurrence of a diapause in marine calanoid copepods. Int. Conc. for the exploration of the sea; Biological Oc. Com. L. 21.

Holm-Hansen, 0. 1971. Microbial distribution in ocean water relative to nutrients and food sources. In "Proceedings of an International Symposium on Biological Sound Scatterina in the Ocean." (G. Brook Farquhar, ed.). 629 pp.

Hopkins, C. C. E., et al ., 1978. Preliminary study of zooplankton and sound scattering layers in Balsfjorden: Structure, energetics, and migrations. Sarsia 63(4):255-264.

Hoos, R. A. W. 1970. Distribution and Physiology of Zooplankton in the oxygen Minimum Layer. M.Sc. Thesis, University of Victoria.

Ikeda, T. 1972. Chemical' composition and nutrition of zooplankton in the Bering Sea. In "Biological Oceanography of Northern North Pacific." (Takenouti, et al., ed.). Tokyo.

Ikeda, T. 1977. The effect of laboratory conditions on the extrapolation of experimental measurements to the ecology of Marine Zooplankton. IV. Changes in respiration and excretion rates of Boreal Zooplankton species maintained under fed and starved conditions. Marine Biology $41: 241-252$.

Jane's Weapons Systems, 1981-82. Edited by R. T. Pretty, Jane's Publishing, Inc. 

Johannes, R. E. and Webb, K. L. 1965. Release of dissolved amino acids by marine zooplankton. Science 150:76-77.

Jorgenson, C. B. 1962. The food of filter feeding organisms. Rapp. Cons. Explor. Mer. 153:99-106.

Judkins, D. C. 1980. Vertical distribution of zooplankton in relation to the oxygen minimum off Peru. Deep Sea Res. 27:475-487.

Koeller, P. 1975. Taxonomy, distribution and aspects of the biology of some deep living copepods in B.C. inlets and adjacent waters. M.Sc. Thesis. University of Victoria.

Koroleff, F. 1970. Direct determination of ammonia in natural waters as indophenol blue. In "Information on techniques and methods for seawater analysis." Interlaboratory Report \#3. 19-22. Cons. Int. Explor. Mer. Service Hydrographique.

Landry, M. R. 1981. Switching between herbivory and carnivory by the planktonic marine copepod Calanus pacificus. Marine Biology. $65: 77-82$.

Lebrasseur, R. J., et al. 1969. Production studies in the Strait of Georgia, Part III. Observations on the food of larval and juvenile fish in the Fraser River plume, February to May, 1967. J. exp. mar. Biol. Ecol. 3:51-61.

Lee, R. L. 1974. Lipids of zooplankton from Bute Inlet, British Columbia. J. Fish. Res. Bd. Can. 31:1577-1582.

Lee, R. F. 1974. Lipid composition of the copepod Calanus hyperboreas from the Arctic Ocean. Changes with depth and season. Marine Biology 26:313-318.

Lee, R. L., Hirota, J. and Barnett, A. M. 1971a. Distribution and importance of wax esters in marine copepods and other zooplankton. Deep Sea Res. 18:1147-1165.

Lee, R. L., Nevenze1, J. C. and Paffenh४fer. 1971b. Importance of wax esters and other lipids in the marine food chain. Mar. Biol. 9:99-108.

Linford, E. 1965. Biochemical studies on marine zooplankton. II. Variations in the lipid content of some Mysidacea. J. Cons. Int. Explor. Mer. 30:76-27.

Littlepage, J. L. 1982. Personal communication. 

Littlepage, J. L. and Rose, D. J. 1974. Feeding and ammonia excretion in wintering Calanus plumchrus. A paper presented at the 37 th Annual Meeting of the Amer. Soc. Limnol. and Oceanogr. University of Washington, Seattle, June 23-28.

Longhurst, A. R. 1967. Vertical distribution of zooplankton in relation to the eastern Pacific oxygen minimum. Deep Sea Research 14:5163 .

Mansingh, A. 1971. Physiological classification of dormancies in insects. Can. Ent. 103:983-1009.

Marlowe, C. J. and Miller, C. B. 1975. Patterns of vertical distribution and migration of zooplankton at Ocean Station "P". Limnol. OC. $20(5): 824-844$.

Marioka, Y. 1972. The vertical distribution of calanoid copepods of the southeast coast of Hokkaido. In "Biological Oceanography of the Northern North Pacific." (Takenouti, J. ed.). Tokyo.

Marsha11, S. M. 1924. The food of Calanus finmarchicus during 1923. J. Mar. Biol. Ass. U.K. 13:473-479. Cited by Adams, J. A. and Steele, J. H. 1966. In "Some Contemporary Studies in Marine Sciences." (H. Barnes, ed.). pp. 19-35. A7len and Unwin, London.

Marsha11, S. M. 1973. Respiration and feeding in Copepods. In "Advances in Marine Biology." Vol. II: 57-120. (F. Russell and M. Yong, ed.).

Marshal1, S. M. and Orr, A. P. 1955. On the biology of Calanus finmarchicus. VIII. Food uptake, assimilation and excretion in adult and stage V Calanus. J. Mar. Biol. Ass. U.K. 34:495-529.

Marsha11, S. M. and Orr, A. P. 1958. On the biology of Calanus finmarchicus. $X$. Seasonal changes in oxygen consumption. J. Mar. BioT. Ass. U.K. 37:459-472.

Martin, J. H. 1968. Phytoplankton - zooplankton relationships in Narragansett Bay. III. Seasonal changes in zooplankton excretion rates in relation to phytoplankton abundance. Limnol. oceanogr. 13:63-71.

Mayzaud, P. 1976. Respiration and nitrogen excretion of zooplankton. IV. The influence of starvation on the metabolism and the biochemical composition of some species. Marine Biology 37:47-58.

Mayzaud, P. and L. M. Martin. 1975. Some aspects of the biochemical and mineral composition of marine plankton. J. exp. Mar. Biol. Ecol. $17: 297-310$. 

Mullin, M. M. 1966. Selective feeding by calanoid copepods from the Indian Ocean. In "Some Contemporary Studies in Marine Sciencę." (H. Barnes ed.) pp. 547-554. ATlen and Unwin, London.

Omori, M. 1969. Weight and chemical composition of some important zooplankton in the North Pacific Ocean. Mar. Biol. 3:4-10.

Orr, A. P. 1934. On the biology of Calanus finmarchicus. IV. Season change on the weight and chemical composition in Loch Fyne. J. Mar. Biol. Ass. U.K. 19:613-632.

Paffenhøfer, G. A. and Strickland, J. D. H. 1970. A note on the feeding of Calanus helgolandicus on detritus. Mar. Biol. 5:97-99.

Parsons, T. R. and Strickland, J. D. H. 1962. Oceanic detritus. Science. $136: 313-314$.

Parsons, T., et al. 1969. Production studies in the Strait of Georgia. Part II. Secondary production under the Fraser River plume, February to May, 1967. J. Exp. Mar. Biol. Ecol. 3:39-50.

Raymont, J. E. G. 1971. Problems of the feeding of zooplankton in the deep sea. In "Proceedings of an International Symposium on Biological Sound Scattering in the Ocean." (G. B. Farquhar, ed.). $629 \mathrm{pp}$.

Riley, G. A. 1959. Note on the particulate matter in Long Island Sound. Bu11. Bingham Oceanogr. Col1. 17:83-86. Cited by Corner, E. D. S. and Cowey, C. B. 1964. Oceanogr. Mar. Biol. Ann. Rev. $2: 147-167$.

Riley, G. A. 1970. Particulate organic matter in seawater. In "Advances in Marine Biology." (F. Russell and M. Yonge, ed.). Vol. 8:1-118.

Riley, G. A. 1963. Organic aggregates in seawater and the dynamics of their formation and utilization. Limnol. Oceanogr. 8:372-381.

Riley, G. A., Wangersky, P. J. and Van Hemert, D. 1964. Organic aggregates in tropical and subtropical surface waters of the North Atlantic Ocean. Limnol. Oceanogr. 9:546-550.

Riley, G. A., Van Hemert, D. and Wangersky, P. J. 1965. Organic aggregates in surface and deep waters of the Sargasso Sea. Limnol. Oceanogr. 10:354-363.

Sameoto, D. D. 1976. Distribution of sound scattering layers caused by euphausids and their relation to chlorophyll-a concentrations in the Gulf of St. Lawrence Estuary. J. Fish. Res. Bd. Can. 33:681687. 

Seki, H. and Kennedy, 0. D. 1969. Marine bacteria ard other heterotrophs as food for zooplankton in the Strait of Georgia during winter. J. Fish. Res. Bd. Can. 26:3165-3173.

Sheldon, R. W., Evelyn, T. P. T. and Parson, T. R. 1967. On the occurrence and formation of small particles in seawater. Limnol. Oceanogr. 7:367-375.

Sokal, R. R. and Rohlf, F. G. 1973. Introduction to Biostatistics. W. H. Freeman Col, San Francisco. $368 \mathrm{pp}$.

Sutcliffe, W. H., Baylor, E. R. and Menzel, D. W. 1963. Sea surface chemistry and Longmuir circulation. Deep Sea Res. 10:233-243.

Taka, S., et al. 1980. Food organisms of Saury, Cololabis Saira, and vertical distribution of zooplankton in the southeas t waters off Kuril Islands. Bul1. Hokkaido Reg. Fish. Res. Lab. 45:15-42.

Taguchi, S. and Ishii, H. 1972. Shipboard experiments on respiration, excretion, and grazing of Calanus cristatus and $C$. plumchrus in the Northern North Pacific. In "Biological Oceanography of the Northern North Pacific." (Takenouti, et a T., ed.). Tokyo.

Tanaka, 0. 1956. The pelagic copepods of the Izu region, middle Japan Systematic Account I. Families Calanidae and Ecucalanidae. Pub1. Seto Mar. Biol. Lab. V(2):251-272.

Urick, R. J. 1975. Principles of Underwater Sound for Engineers, 2nd Ed. McGraw Hill.

Vinogradov, M. E. 1962. Feeding of the deep-sea zooplankton. Rapp. Cons. Explor. Mer. 153:114-120.

Zobe11, C. E. and Anderson, D. Q. 1936. Observations on the multiplication of bacteria in different volumes of stored seawater and the influence of oxygen tension and solid surface. Biol. Bu17. 71: 324-342. 

1. Defense Technical Information Center Cameron Station

Alexandria, VA 22314

2. Library, Code 0142

Naval Postgraduate School

Monterey, CA 93940

3. Chairman, Code 68

Department of Oceanography

Naval Postgraduate School

Monterey, CA 93940

4. Professor Eugene C. Haderlie, Code $68 \mathrm{HC}$ Department of Oceanography Naval Postgraduate School Monterey, CA 93940

5. Calvin Dunlap, Code $68 \mathrm{Du}$ Department of Oceanography Naval Postgraduate School Monterey, CA 93940

6. CAPT M. B. Cowen

Fleet School Oceanography Instructor CFFS Halifax

CFB Halifax, Halifax

Nova Scotia, Canada

B3K2XO

7. Director

Naval Oceanography Division

Navy Observatory

34th and Massachusetts Avenue NW Washington, DC 20390

8. Commander

Naval Oceanography Command

NSTL Station

Bay St. Louis, MS 39529 

9. Commandant

Canadian Forces Fleet School

CFB Halifax

Halifax, Nova Scotia, Canada

B3K2X0

10. Commanding Officer

Naval Ocean Research and Development Activity

NSTL Station

Bay St. Louis, MS 39522

11. Chairman, Oceanography Department

U.S. Naval Academy

Annapolis, MD 21402

12. Scientific Liaison Office

Office of Naval Research

Scripps Institution of Oceanography

La Jolla, CA 92037

13. Library

Scripps Institution of Oceanography

P.0. Box 2367

La Jolla, CA 92037

14. Library

Department of Oceanography

University of Washington

Seattle, WA 98105

15. Library

CICESE

P. 0 . BOX 4803

San Ysidro, CA 92073

16. Library

School of Oceanography

Oregon State University

Corvallis, OR 97331

17. Commander

Oceanographic Systems Pacific

Box 1390

Pearl Harbor, HI 96860 

18. Defence Research Board

Department of National Defence

$1900^{\prime}$ Connor Street

Ottawa, Ontario KIA OZ3,

Canada

19. Library

Moss Landing Marine Lab

California State Colleges

Sandholdt Road

Moss Landing, CA 95039

20. Library

Defense Research Establishment Pacific

Fleet Mail Office

Esquimalt, D.C.

Canada

21. Library

Hopkins Marine Station

Pacific Grove, CA 93950

22. National Defense Headquarters

DPED 2-5

Ottawa, Ontario

Canada KIA OK2

23. Library

Institute of Ocean Sciences, Patricia Bay

P.0. Box 6000

9860 West Saanich Rd.

Sidney, B.C.

Canada V8L4B2

24. Library

Ocean and Aquatic Sciences,

Department of Fisheries and Oceans,

240 Sparks St.

7 th Floor, West,

Ottawa, Canada KTAOE4

25. MARINE SCIENCES CENTRE

MCGILL UNIVERSITY

3620 University St.

P.0. Box 6070

Montrea 1, Quebec

Canada H3A2T8 

No. Copies

26. Library

Bedford Inst. of Oceanography, Darmouth, H.S.,

Canada B2Y4A2

27. Departmental Library-Serials Department of the Environment Ottawa, Canada K1A OH3 




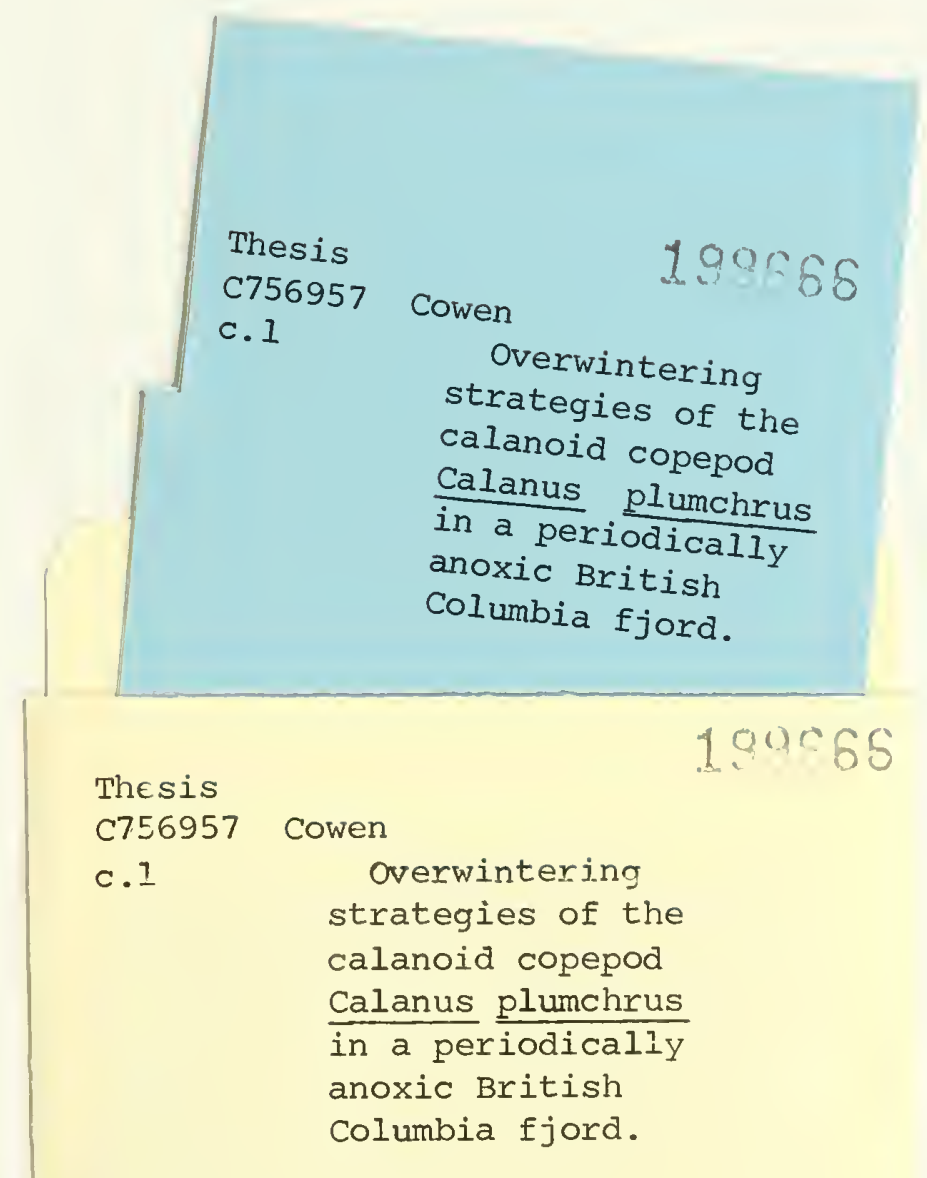


Overwintering strategies of the calanoid

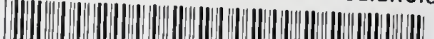

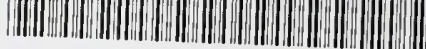

32768002090045

DUDLEY KNOX LIBRARY 